\title{
Site Selection for Surplus Plutonium Disposition Facilities at the Savannah River Site
}

by

L. D. Wike

Westinghouse Savannah River Company

Savannah River Site

Aiken, South Carolina 29808

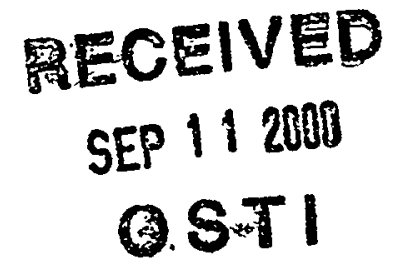

DOE Contract No. DE-AC09-96SR18500

This paper was prepared in connection with work done under the above contract number with the U. S. Department of Energy. By acceptance of this paper, the publisher and/or recipient acknowledges the U.S. Government's right to retain a nonexclusive, royalty-free license in and to any copyright covering this paper, along with the right to reproduce and to authorize others to reproduce all or part of the copyrighted paper. 


\section{DISCLAIMER}

This report was prepared as an account of work sponsored by an agency of the United States Government. Neither the United States Government nor any agency thereof, nor any of their employees, makes any warranty, express or implied, or assumes any legal liability or responsibility for the accuracy, completeness, or usefulness of any information, apparatus, product or process disclosed, or represents that its use would not infringe privately owned rights. Reference herein to any specific commercial product, process or service by trade name, trademark, manufacturer, or otherwise does not necessarily constitute or imply its endorsement, recommendation, or favoring by the United States Government or any agency thereof. The views and opinions of authors expressed herein do not necessarily state or reflect those of the United States Government or any agency thereof.

This report has been reproduced directly from the best available copy.

Available for sale to the public, in paper, from: U.S. Department of Commerce, National Technical Information Service, 5285 Port Royal Road, Springfield, VA 22161, phone: (800) 553-6847, fax: (703) 605-6900 email: orders@ntis.fedworld.gov online ordering: http://www.ntis.gov/ordering.htm

Available electronically at http://www.doe.gov/bridge Available for a processing fee to U.S. Department of Energy and its contractors, in paper, from: U.S. Department of Energy, Office of Scientific and Technical Information, P.O. Box 62, Oak Ridge, TN 37831-0062, phone: (865)576-8401, fax: (865) $576-5728$ email: reportsladonis.osti.gov 


\section{DISCLAIMER}

Portions of this document may be illegible in electronic image products. Images are produced from the best available original document. 
AUG 022000

PDP-GEN-2000-00018

RETENTION: Permanent

RSM \#10560

Mr. Charles E. Anderson, Director

Nuclear Material Disposition Division

United States Department of Energy

Savannah River Operations Office

P.O. Box A

Aiken, SC 29802

Dear Mr. Anderson:

\section{FINAL REPORT - SITE SELECTION FOR SURPLUS PLUTONIUM DISPOSITION FACILITIES}

Ref: Letter UG-00-124, titled Site Confirmation for Plutonium Disposition Facilities, from C. E. Anderson to J.G. Angelos, dated April 6, 2000

In response to your request of April 6, 2000, attached is the final report WSRC-RP-2000-00391, titled Site Selection for Surplus Plutonium Disposition Facilities at the Savannah River Site. The site evaluation team evaluated a total of nine sites in and around F Area. WSRC recommends placement of MOX on site 2, PDCF on site X and PIP on site 5.

The process evaluated sites 2 and $X$ for their suitability to the Mixed Oxide Fuel Fabrication Facility (MOX) and Pit Disassembly and Conversion Facility (PDCF) missions, respectively. The remaining seven sites were evaluated for their suitability to the plutonium disposition mission. Though some sites were evaluated as more conducive than others to the construction and operation of the plutonium disposition facilities, none were found to be unacceptable.

Based on prior DOE decisions to use site $\mathrm{X}$ for PDCF and site 2 for MOX, the team did not consider whether those decisions represent the optimum arrangement of these facilities among the three sites and did not attempt to evaluate or optimize the placement of individual structures within the assigned plots. The team determined that sites 2 and $\mathrm{X}$ are suitable for the siting of new facilities, and therefore confirmed as acceptable DOE's previous decision to use site $\mathrm{X}$ for $\mathrm{PDCF}$ and site 2 for MOX.

Site 1 was found to include a hazardous waste unit and a grouted section of process sewer line the soil around which may not be disturbed for a distance of 20 feet on either side. Thesefindings led the team to conclude that site 1 should be moved westward approximately 200 yards resolving the sewer line obstacle but further distancing site 1 from PDCF. Site 1 then scored highest overall in the evaluation process, however its distance from PDCF increased. 
C. E. Anderson

PDP-GEN-2000-00018

AUG 022000

Page 2

Site 5 (including the area immediately to the west of it) was judged by the site evaluation team to be acceptable and has the advantage of being adjacent to the proposed PDCF site, X. Placing PDCF and PIP on adjacent sites significantly increases the flexibility of design of common features and services including the PIDAS configuration options, distribution of utilities, support facilities, etc. Therefore, the WSRC Plutonium Disposition Program recommends that site 5 be selected as the preferred site for the PIP facility. It is further recommended that the site 1 serve as an alternate site should a recommended site prove to be unacceptable.

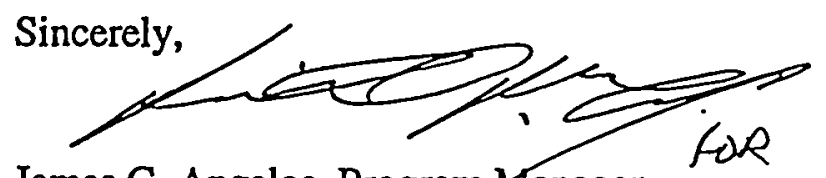

James G. Angelos, Program Hanager

Plutonium Disposition Program

RRT:ebs

Att.

c: R. F. Billue, 703-42A

D. L. Bruner, 703-42A

J. M. Francis, 703-42A

S. King, 703-45A

E. P. Maddux, 703-45A

R. L. Geddes, 703-45A

J. S. Roberts, 703-45A

R. R. Tansky, 703-A

File: Pu Disp. 


\title{
Site Selection for
}

\section{Surplus Plutonium Disposition Facilities}

\section{At the Savannah River Site}

\author{
L. D. Wike, Compiler
}

July 2000

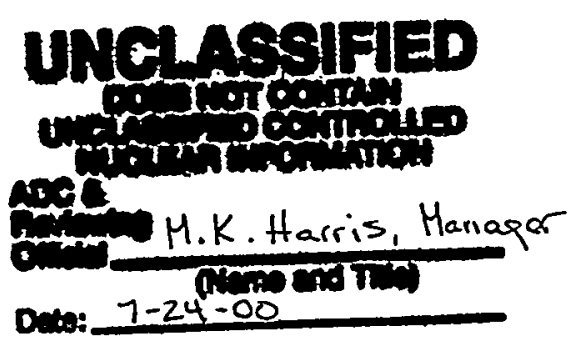

Prepared by:

Westinghouse Savannah River Company Savannah River Site Ailken, SC 29808

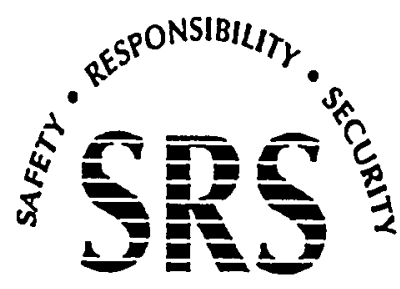

Prepared for the U.S. Department of Energy Under Contract Number DE-AC09-96SR18500 


\title{
Site Selection for
}

Surplus Plutonium Disposition Facilities

\section{At the Savannah River Site}

\author{
L. D. Wike, Compiler
}

July 2000

Prepared by:

Westinghouse Savannah River Company

Savannah River Site

Aiken, SC 29808

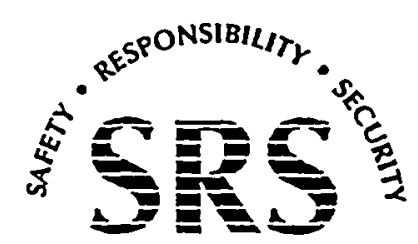

Prepared for the U.S. Department of Energy Under

Contract Number DE-AC09-96SR18500 


\section{TABLE OF CONTENTS}

1.0 INTRODUCTION.

1.1 Synopsis of Site Selection Process ...

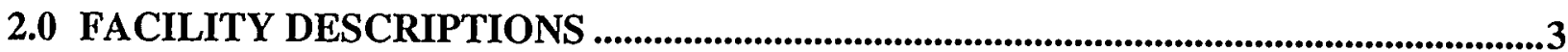

3.0 SITE SELECTION FOR SURPLUS PLUTONIUM DISPOSITION FACILITIES ......4

3.1 Determination of Exclusion Criteria ......................................................................................... 4

3.2 Candidate Site Locations ............................................................................................. 4

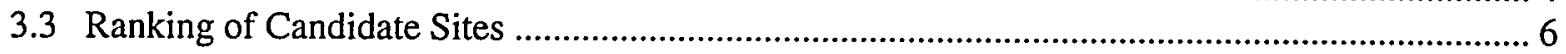

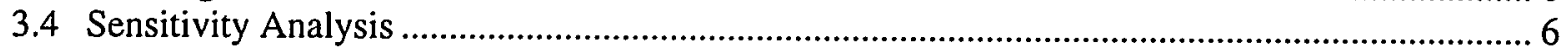

4.0 COMPARATIVE EVALUATION OF CANDIDATE SITES...............................................7

4.1 Rationale for Scoring Categories and Subcategories ............................................................ 8

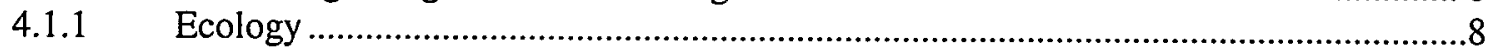

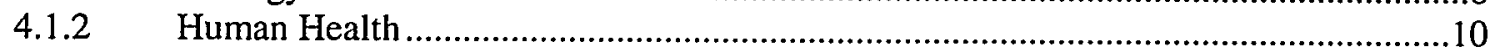

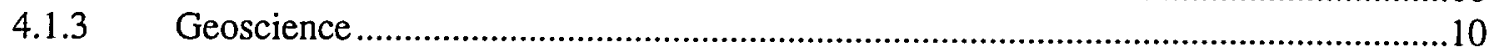

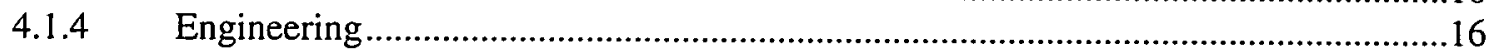

4.2 Scoring of Candidate Sites .....................................................Error! Bookmark not defined.

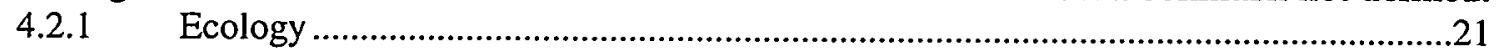

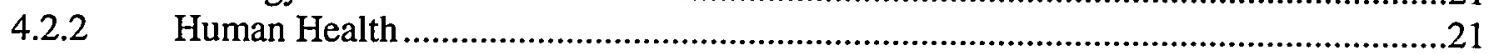

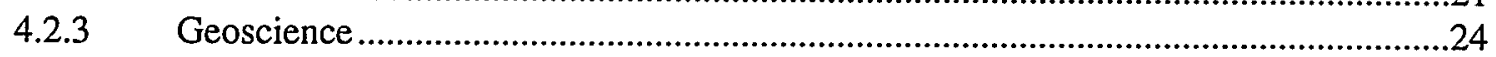

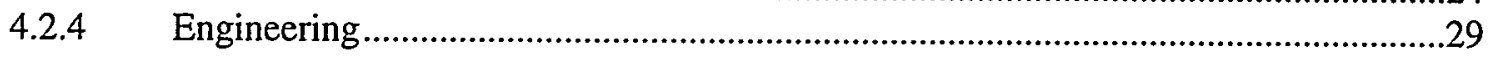

5.0 CONCLUSIONS ...............................................................................................................31

6.0 REFERENCES ....................................................................................................32 


\section{List of Figures}

Figure 1: Location of F-Area Within Savannah River Site ................................................................

Figure 2: Potential PuDF Sites in Relation to Area Streams and Wetlands ...........................................

Figure 3: Potential Pu DFSites in Relation to F-Area MEI Locations.....................................................11

Figure 4: Potential PuDF Sites in Relation to F-Area Topography.....................................................14

Figure 5: Potential PuDF Sites Relative to Depth to Water Table...........................................................15

Figure 6: Potential PuDF Sites in Relation to F-Area Road and Rail Systems.........................................19

\section{List of Tables}

Table 1: Geoscience Categories and Specific Scoring Criteria.............................................................12

Table 2: Summary of Scoring for PuDF Sites..........................................................................................20

Table 3: Geoscience Criteria Scoring Summary ..........................................................................................24 


\section{EXECUTIVE SUMMARY}

A site selection study was conducted to evaluate locations for the proposed Surplus Plutonium Disposition Facilities. Facilities to be located include the Mixed Oxide (MOX) Fuel Fabrication Facility, the Pit Disassembly and Conversion Facility (PDCF), and the Plutonium Immobilization Project (PIP) facility. Objectives of the study include:

- Confirm that the Department of Energy (DOE) selected locations for the MOX and PDCF were suitable based on selected siting criteria,

- Recommend a site in the vicinity of F Area that is suitable for the PIP,

- Identify alternative suitable sites for one or more of these facilities in the event that further geotechnical characterization or other considerations result in disqualification of a currently proposed site.

The site selection process considers facility-specific requirements, sensitive environmental resources and regulatory requirements. The primary objectives of the process are cost minimization, environmental protection, and regulatory compliance.

Nine locations (i.e., Sites 1, 2, 3, 4, 5, 6, 7, X, and the Actinide packaging and Storage Facility \{APSF\} Site) in the vicinity of F Area were considered for the proposed facilities. Exclusion criteria were applied to assure that all sites were minimally acceptable and suitable for the proposed facilities. Ranking criteria based upon ecological, human health, geoscience, and engineering factors were then applied to all sites. A comparative analysis indicated that four of the sites had similar high scores and two other sites had comparable low scores. The remaining three sites had intermediate scores.

It is concluded that Sites $1, \mathrm{X}$, and 2 are the best suited for the proposed missions based on their total scores. Sites 3 and 4 are the least favorably disposed for the missions. Sites 5, 6, and 7 possessed intermediate scores and would be suitable for the proposed facilities. Irrespective of its small area, the APSF site scored well and could be considered for additional space for Sites 2 and $X$. Although Site 5 is acceptable for use in these projects, current uses and environmental issues could result in adverse cost or schedule impacts that must be considered in any final siting decisions. Additionally, the presence of the Old F-Area seepage basin and process sewer line necessitates that Site 1 be considered for use by a facility that does not require underground connections to other facilities in the complex.

Significant opportunities exist for optimization in the placement of individual facilities as the requirements for those facilities are better defined. Such optimization could include examining subsets of currently defined sites or expansion of certain sites to create parcels more amenable to facility operations. The areas including, and adjacent to Site 5 warrant consideration in this regard, but will require further evaluation. 


\subsection{INTRODUCTION}

The purpose of this study is to identify, assess and rank potential sites for the proposed Surplus Plutonium Disposition Facilities (PuDF) complex at the Savannah River Site (SRS). Three individual facilities are associated with the PuDF complex: Mixed Oxide Fuel Fabrication Facility (MOX); Pit Disassembly and Conversion Facility (PDCF); and the Plutonium Immobilization Project (PIP) facility. The study effort documented in this report was limited by analyses presented in the Surplus Plutonium Disposition Final Environmental Impact Statement (DOE, 1999), which restricted these facilities to locations in the vicinity of the F-Area processing facility at the Savannah River Site (SRS). Additionally, prior to initiation of this study, preferred sites had been identified by the Department of Energy (DOE) for construction and operation of both the MOX and PDCF.

The objectives for this facility siting study were to:

- Confirm that the DOE selected locations for the MOX and PDCF were suitable based upon selected environmental and engineering criteria,

- Recommend a site in the vicinity of F Area that is suitable for the PIP,

- Identify alternative suitable sites for one or more of these facilities should further geotechnical characterization or other considerations result in disqualification of a currently proposed site.

This study does not consider the impact on siting alternatives of ongoing studies concerning the possibility of supplying certain support services from consolidated facilities (e.g., inert gas storage, backup power, cooling water/chilled water, etc.) or the potential for future studies to identify advantages of combining major facility functions (e.g., shipping/receiving, waste handling, analytical labs, etc) into a common unit.

\subsection{Synopsis of Site Selection Process}

The site selection method utilized a simple decision-making process based on Nominal Group, Delphi and Decision Analysis techniques (Howard and Matheson, 1968; Wike, 1995). A panel of subject matter experts knowledgeable in the areas of facility engineering, regulatory compliance (e.g., National Environmental Policy Act or NEPA) and environmental sciences implemented this process.

A listing of panel members and their organizational affiliations is as follows:

J. B. Gladden (chair)

R. L. Geddes

M. R. Lewis

M. E. Maryak

P. H. Porter, Jr.

C. B. Shedrow

R. R. Tansky

L. D. Wike

D. E. Wyatt
SRTC/ESTD

SI\&PD/PU\&APT

PE\&CD/SGS

PE\&CD/SGS

PE\&CD/Construction

ESH\&QA/EPD

TSD

SRTC/ESTD

PE\&CD/SGS 
Following the identification of potential PuDF locations within the vicinity of $F$ Area, the panel determined the most suitable locations for project implementation. These locations were numerically ranked using a system of mutually agreed upon scoring categories that were weighted according to their relative importance. The siting evaluation reported in this document is based on information available at the time of the study. Of particular note is the variability in abundance and quality of geotechnical data available to support the assessment. Consequently, the sites identified as most suitable will undergo an in-depth geotechnical examination to confirm their acceptability for construction and operation of the individual PuDF.

\subsection{FACILITY DESCRIPTIONS}

The three facilities proposed for surplus plutonium disposition involve processes related to pit conversion, plutonium immobilization, and mixed oxide fuel fabrication. Each process would be carried out within its own specific facility. Pit conversion would be done in the PDCF, immobilization would be conducted in the PIP facility, and mixed oxide fuel assemblies for domestic commercial power reactors would be produced in the MOX Facility. The site selection was completed based on early design concepts. Detailed design data for the proposed facilities were not available.

PDCF would be housed in a two-story building roughly 250,000 square feet. The building would be constructed of hardened concrete walls designed and built to withstand natural phenomena hazards as well as potential facility accidents. Ancillary buildings for support activities and parking lots would also be part of the complex. A generalized description of the pit disassembly and conversion process can be found in DOE, 1999.

Immobilization of plutonium not used for mixed oxide fuel would be conducted in the PIP facility. This operation would convert various forms of plutonium into plutonium dioxide, which would then be converted into a glass or ceramic form. This form would be sealed in cans and placed in canisters at the Defense Waste Processing Facility (DWPF) for final immobilization. The building would be constructed of hardened concrete designed and built to withstand natural phenomena hazards as well as potential facility accidents (DOE, 1999). Specific data concerning building size and facility footprint are not currently available.

The MOX consists of the mixed oxide fuel Fabrication Building and a variety of support structures. The mixed oxide fuel Fabrication Building is over 370,000 square feet and consists of the mixed oxide fuel Processing Area, Aqueous Polishing Area, and the Shipping and Receiving Area. Ancillary buildings include a diesel generator building, material receipt area, a secured warehouse, an administration building, access control, and a technical support building. The MOX complex is a multi-story structure built to meet all requirements for handling special nuclear material. The three-component building would be constructed of hardened concrete designed and built to withstand natural phenomena hazards as well as potential facility accidents (DCS\&W, 2000). 
WSRC-RP-2000-00391

July 24,2000

\subsection{SITE SELECTION FOR SURPLUS PLUTONIUM DISPOSITION FACILITIES}

\subsection{Determination of Exclusion Criteria}

The first step in the site selection process was the selection of exclusion criteria to serve as an initial screen for identifying potential development locations. The use of exclusion criteria ensures that the PuDF will not be located in areas where they could (a) adversely impact critical SRS environmental resources, (b) present a threat to human health (both on- and offsite populations) or (c) be exposed to known physical hazards and/or regulatory risks. The use of exclusion criteria minimizes the potential for project-related environmental impacts, thereby diminishing the need for significant post-Record of Decision (ROD) mitigation measures. Following is a list of exclusion criteria utilized for the PuDF siting process.

The various components of the PuDF will not be located:

- where they would encroach upon or adversely impact wetlands, high quality surface streams, waterbodies or other high value ecological resources (e.g., National Environmental Research Park Sites, pristine habitats);

- where they would adversely impact any known or proposed threatened or endangered species or their critical habitat;

- within a 100-year floodplain;

- on 'high risk' waste sites;

- in areas of known geologic risks;

- in areas of known significant groundwater contamination within the construction envelope, assumed to be 35 feet below grade based on preliminary engineering for the MOX;

- within one mile from the SRS boundary, and

- so as to contravene relevant NEPA documentation.

\subsection{Candidate Site Locations}

All candidate sites are located within the vicinity of F-Area (Figure 1) as described in the DOE, (1999). General descriptions of the candidate sites follow:

\begin{tabular}{|l|l|}
\hline Site 1 & $\begin{array}{l}\text { Site } 1 \text { is located along the northwest boundary of F Area. Historically, the site was } \\
\text { used as a parking and laydown area for F-Area construction-related activities. The } \\
\text { northern portion of this site contains the Old F-Area Seepage Basin waste unit, } \\
\text { process sewer line, and associated contaminant plume. This waste unit is in the } \\
\text { final stages of Resource Conservation and Recovery Act (RCRA) closure. } \\
\text { Topographically, this site is relatively flat. Drainage from the site is to the north- } \\
\text { northeast toward tributaries of Upper Three Runs. Site 1 encompasses an area of } \\
\text { approximately } 25 \text { acres. }\end{array}$ \\
\hline Site 2 & $\begin{array}{l}\text { Site } 2 \text { is located due north and adjacent to the F-Area boundary. Sites } 1 \text { and X are } \\
\text { located to the southwest and southeast of Site 2, respectively. Historically, the site } \\
\text { has been used as a spoils pile disposition area for F-Area construction-related } \\
\text { activities, most recently for the APSF excavation project. Topographically, Site } 2 \\
\text { slopes to the northeast and drains toward a tributary of Upper Three Runs. Site } 2 \\
\text { encompasses an area of approximately } 32 \text { acres. }\end{array}$ \\
\hline
\end{tabular}




\begin{tabular}{|c|c|}
\hline APSF Site & $\begin{array}{l}\text { The APSF Site is located within the F-Area complex, near the northeast boundary } \\
\text { corner. Historically, this site has been used as a laydown area for F-Area } \\
\text { construction-related activities. This site is relatively flat, but presently contains a } \\
\text { large engineered excavation approximately } 35 \text { feet below existing grade. For } \\
\text { purposes of the site evaluation process, it was assumed that this excavation would } \\
\text { be backfilled to existing level grade. Drainage on the site is to the northeast } \\
\text { through Site } 2 \text { to a tributary of Upper Three Runs. The APSF Site encompasses an } \\
\text { area of approximately } 4 \text { acres. }\end{array}$ \\
\hline Site X & $\begin{array}{l}\text { Site X is located on the northeast boundary of F Area, immediately adjacent to Sites } \\
2,4 \text {, and } 5 \text {, respectively. Historically, this site was used as a laydown area for F- } \\
\text { Area construction-related activities. Topographically, the site slopes to the } \\
\text { north/northeast and drains to a tributary of Upper Three Runs, which courses } \\
\text { through Site 4. Site X encompasses an area of approximately } 26 \text { acres. }\end{array}$ \\
\hline Site 3 & $\begin{array}{l}\text { Site } 3 \text { is located approximately } 1500 \text { feet northeast of the F-Area boundary, } \\
\text { adjacent to the Burial Ground Expansion Area. This site is physically separated } \\
\text { from the F-Area complex by a draw that contains a tributary to Upper Three Runs } \\
\text { and also in part by land areas associated with Sites } 4 \text { and X. Historically, the site } \\
\text { has been used as a source of borrow material. Topographically, this site is } \\
\text { relatively flat, with drainage to the northeast and southwest to tributaries of Upper } \\
\text { Three Runs. Site } 3 \text { encompasses an area of approximately } 25 \text { acres. }\end{array}$ \\
\hline Site 4 & $\begin{array}{l}\text { Site } 4 \text { is located approximately } 900 \text { feet northeast of the F-Area boundary and } \\
\text { approximately } 300 \text { feet northwest of the Mixed Waste Management Facility. This } \\
\text { site is physically separated from the F-Area complex by the land areas associated } \\
\text { with Sites X and } 5 \text {, respectively. Historically, this site has never been used or } \\
\text { developed. Site } 4 \text { is topographically low and possesses significant slope due to the } \\
\text { presence of a tributary to Upper Three Runs. Site } 4 \text { encompasses an area of } \\
\text { approximately } 46 \text { acres. }\end{array}$ \\
\hline Site 5 & $\begin{array}{l}\text { Site } 5 \text { is located northeast of the F-Area boundary, immediately adjacent to Sites X } \\
\text { and } 4, \text { respectively. Historically, this site has been used as a debris or spoils pile } \\
\text { disposition area and the site presently contains an active ash disposal basin. } \\
\text { Topographically, the site drains to the north through the Upper Three Runs } \\
\text { tributary, which courses through Site } 4 \text {. Site } 5 \text { encompasses an area of } \\
\text { approximately } 26 \text { acres. Site } 5 \text { was not excluded from consideration because the } \\
\text { ash basin is not considered a "high risk" waste site and the underlying contaminated } \\
\text { groundwater plume lies well below the construction envelope of the proposed } \\
\text { facilities. }\end{array}$ \\
\hline Site 6 & $\begin{array}{l}\text { Site } 6 \text { is located along the southwestern boundary of F Area and is bounded on its } \\
\text { southern margin by SRS Road C. Historically, this site has served as a forest buffer } \\
\text { between the F-Area complex and heavily traveled SRS Road C. Topographically, } \\
\text { Site } 6 \text { is relatively flat and possesses a slight slope to the south-southeast. Drainage } \\
\text { from the area is towards Fourmile Branch. Site } 6 \text { encompasses an area of } \\
\text { approximately } 34 \text { acres. }\end{array}$ \\
\hline
\end{tabular}


WSRC-RP-2000-00391

July 24,2000

\begin{tabular}{|l|l|}
\hline Site 6 & $\begin{array}{l}\text { Site } 6 \text { is located along the southwestern boundary of F Area and is bounded on its } \\
\text { southern margin by SRS Road C. Historically, this site has served as a forest buffer } \\
\text { between the F-Area complex and heavily traveled SRS Road C. Topographically, } \\
\text { Site } 6 \text { is relatively flat and possesses a slight slope to the south-southeast. Drainage } \\
\text { from the area is towards Fourmile Branch. Site } 6 \text { encompasses an area of } \\
\text { approximately } 34 \text { acres. }\end{array}$ \\
\hline Site 7 & $\begin{array}{l}\text { Site } 7 \text { is located approximately } 2500 \text { feet south-southwest of F Area, immediately } \\
\text { south of SRS Road C across from Site } 6 . \text { Historically, the site has been used as a } \\
\text { borrow pit and presently hosts the Burma Road Rubble Pile Waste Unit. This site } \\
\text { is located on a topographic high, with drainage southward toward Fourmile Branch. } \\
\text { Site } 7 \text { encompasses an area of approximately } 61 \text { acres. }\end{array}$ \\
\hline
\end{tabular}

\subsection{Ranking of Candidate Sites}

All sites considered for evaluation are generally acceptable for use by the facilities being sited because of the initial application of screening or exclusion criteria. The process of ranking sites serves to optimize the placement of facilities by further minimizing potential environmental impacts and reducing difficulties that might arise during construction or

- operation of facilities. As previously noted, the scoring and ranking presented in this document is based on available data and additional confirmatory geotechnical characterization of the most favorable sites will be required prior to project construction.

\subsection{Sensitivity Analysis}

Sensitivity analysis has demonstrated that Sites 1,2, APSF and X are best suited over widely varying error ranges in primary weights. The primary weights representing the relative importance of ecology, human health, geoscience, and engineering present the greatest potential for variability. Secondary weights representing the criteria within the categories were considered to be of lesser variability since category experts determined them. They were not varied. The primary weights were simultaneously varied from $10 \%$ to $40 \%$ using the method of extreme vertices. Statistical analysis of the resulting weighted scores confirmed the robustness of the site selection (Harris, 2000). 

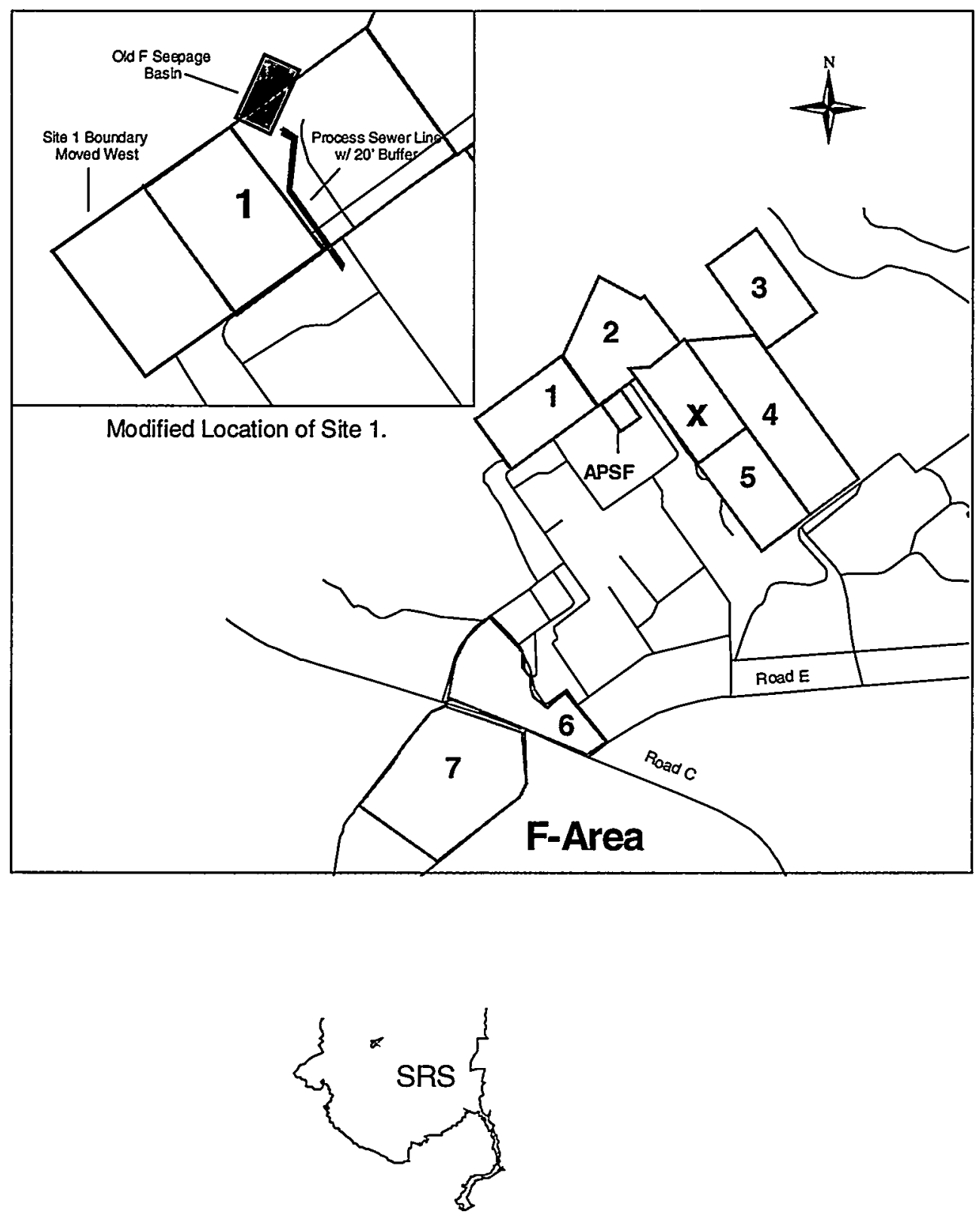

Figure 1. Location of F-Area Within Savannah River Site. 


\subsection{COMPARATIVE EVALUATION OF CANDIDATE SITES}

\subsection{Rationale for Scoring Categories and Subcategories}

\subsubsection{Ecology}

The SRS has many sensitive ecological features including areas where plants and animals of concern are found, endangered species and their management areas, pristine headwater streams and wetlands (Figure 2), and ecological research set-aside areas. All of these attributes of the ecological resources must be considered in siting a project because they can be expensive or impossible to remediate if not properly considered and can cause cost and scheduling difficulties.

- Terrestrial Ecology: Location and operation of the facility should minimize impacts to plant and animal species located near the project and not degrade -existing conditions. Site location should avoid areas containing high-value, limited-availability resources and ecological communities. A site in a developed area, recent clear-cut area, or area containing early growth pine plantation would have minimal terrestrial resource impact and would score highly for this category.

- Wetlands Ecology: The SRS has a policy of no net loss of wetlands. Therefore, the project should be located to avoid any loss of wetlands. Sites are favored that minimize potential impacts to this habitat type. Sites nearer to low quality wetlands (e.g., those associated with degraded streams) and those with no potential wetland impacts will score higher than sites near high quality wetlands.

- Aquatic Ecology: The proposed project should be sited to minimize impacts to aquatic resources during construction and operation of the facility. Erosion control and storm water runoff are important considerations. Sites near high quality streams would score lower than those situated near degraded or previously impacted streams. 


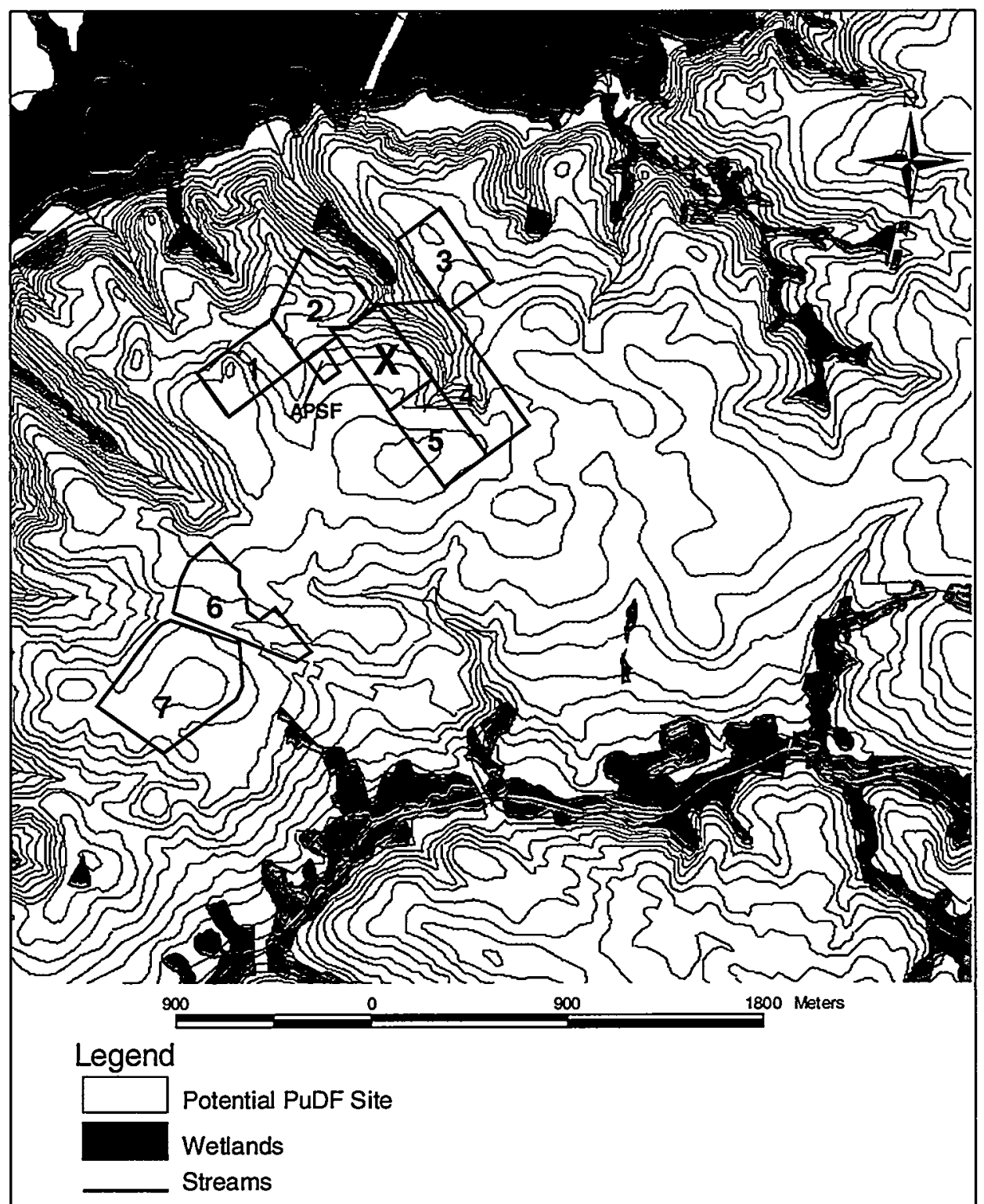

Figure 2. Potential PuDF Sites in Relation to Area Streams and Wetlands. 


\subsubsection{Human Health}

Human health considerations include radiological effects and emergency preparedness. Radiological considerations for releases include offsite risk, potential effects on SRS workers from the proposed facility, and effect from existing facilities on workers at the proposed facility. (Figure 3)

- Risk to Offsite Population: As part of the site selection, doses to the offsite maximally exposed individual (MED) have been determined for each location. Sites presenting lower risks to offsite populations score highest.

- Effect on PuDF Workers from Nearby Facilities: Doses were determined for a PuDF worker assuming a release from a nearby onsite radiological facility.

- Effect of PuDF on Workers in Nearby Facilities: The effects of releases from PuDF on workers in existing nearby facilities was assessed by evaluating proposed locations with respect to locations of workers in existing onsite facilities and prevailing wind directions for SRS.

- Emergency Response/Preparedness: Emergency preparedness considers protective actions, fire and emergency medical response which is measured in time for response from the nearest stations, and proximity to additional onsite hazards. Protective action considers availability of shelter and the number, direction, and congestion of evacuation routes. It was assumed for the purpose of analysis that each candidate location would have stand-alone employee notification and fire suppression systems in place (Matthews, 2000).

\subsubsection{Geoscience}

Five geoscience categories were evaluated including: topography, surface hydrology, subsurface hydrology, geology, and seismology Each of these categories was further subdivided into specific survey criteria. The importance of each category was weighted against the other categories. Consideration was given to the overall geographical location as well as geoscience experience in the vicinity. Each of the categories is described in Table 1 with relative percentage weights and scores per subdivision. 


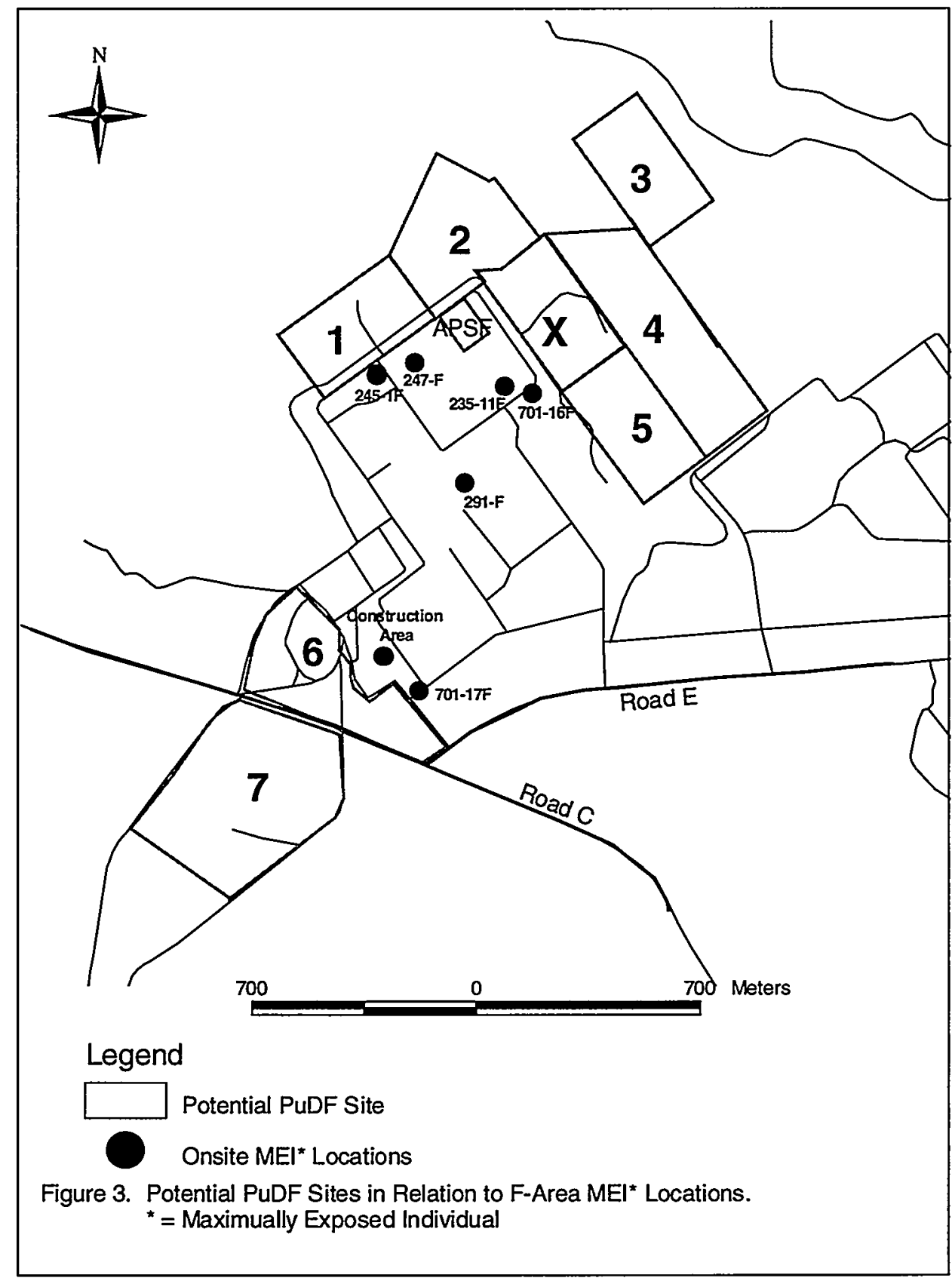


Table 1. Geoscience Categories and Specific Scoring Criteria

\begin{tabular}{|c|c|c|c|c|}
\hline $\begin{array}{l}\text { Specific } \\
\text { Criterion } \\
\end{array}$ & Description & Criteria & $\begin{array}{l}\text { Scoring } \\
\text { Values }\end{array}$ & $\begin{array}{l}\text { Max } \\
\text { Score }\end{array}$ \\
\hline Topography & Wholn & 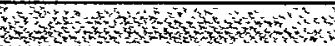 & 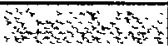 & $\begin{array}{ll}-5 \\
45\end{array}$ \\
\hline $\begin{array}{l}\text { Site topography } \\
\text { Figure } 4\end{array}$ & $\begin{array}{l}\text { Topography within the possible project } \\
\text { boundaries including the existence of hills, } \\
\text { depressions, and slopes were evaluated. } \\
\text { Site development on a flat site would cost } \\
\text { less compared to a hilly site. Furthermore, } \\
\text { steep slopes present potential adverse } \\
\text { affects on slope stability. }\end{array}$ & $\begin{array}{l}\text { Hilly, moderate, } \\
\text { flat }\end{array}$ & $0,1,2,3$ & 3 \\
\hline Natural drainage & $\begin{array}{l}\text { Drainage improvement would cost less for } \\
\text { a well-drained site compared to a poorly } \\
\text { drained site. }\end{array}$ & $\begin{array}{l}\text { Poor, good, } \quad: \\
\text { acceptable } \quad \vdots\end{array}$ & $0,1,2,3$ & 3 \\
\hline $\begin{array}{l}\text { At facility } \\
\text { footprint }\end{array}$ & $\begin{array}{l}\text { Construction of the main facility on even } \\
\text { surfaces requires less cut and fill. } \\
\text { Placement of structural fill under heavy } \\
\text { structures requires additional attention to } \\
\text { avoid excessive settlement. }\end{array}$ & $\begin{array}{l}\text { Hilly, moderate, } \\
\text { flat }\end{array}$ & $0,1,2,3$ & 3 \\
\hline $\begin{array}{l}\text { Balanced cut \& } \\
\text { fill at } \\
\text { foundation } \\
\text { footprint }\end{array}$ & $\begin{array}{l}\text { If a balanced cut and fill is unachievable, a } \\
\text { borrow pit or stockpile needs to be located. } \\
\text { The cost for transporting the material is } \\
\text { dependent on the amount of material and } \\
\text { the distance of transportation. }\end{array}$ & $\begin{array}{l}\text { Haul distance } \\
\text { greater than } 2 \text { miles, } \\
\text { haul distance } 0 \text { to } 2 \\
\text { miles, balanced cut } \\
\text { and fill }\end{array}$ & $0,1,2,3$ & 3 \\
\hline $\begin{array}{l}\text { Road and rail } \\
\text { profiles }\end{array}$ & $\begin{array}{l}\text { Access roads and rail spurs will be } \\
\text { constructed connecting the facility to the } \\
\text { existing road or rail. Slopes as well as } \\
\text { amount of cuts and fills for constructing } \\
\text { the transportation routes are evaluated. }\end{array}$ & $\begin{array}{l}\text { Large slopes, cuts } \\
\text { and fills; moderate } \\
\text { slopes, cuts and fill; } \\
\text { nominal slopes cut } \\
\text { and fill }\end{array}$ & $0,1,2,3$ & 3 \\
\hline $\begin{array}{l}\text { Surface } \\
\text { Hy drology }\end{array}$ & 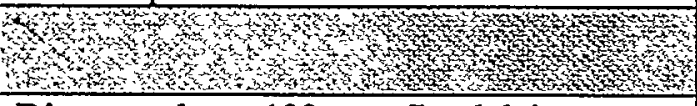 & & & \\
\hline $\begin{array}{l}\text { Proximity to } \\
\text { floodplain }\end{array}$ & Distance above 100 year floodplain & $\begin{array}{l}\text { Near } 100 \text { year flood } \\
\text { plain, } 10-50 \mathrm{ft} \\
\text { above } 100 \text { yr. flood } \\
\text { plain, greater than } \\
50 \mathrm{ft} \text { above }\end{array}$ & $\begin{array}{l}0,1-7 \\
8-10\end{array}$ & 10 \\
\hline Local flooding & Response to rainfall & $\begin{array}{l}\text { Significant local } \\
\text { ponding, moderate } \\
\text { local ponding, } \\
\text { nominal local } \\
\text { ponding }\end{array}$ & $0,1-4,5$ & 5 \\
\hline
\end{tabular}




\begin{tabular}{|c|c|c|c|c|}
\hline $\begin{array}{l}\text { Specific } \\
\text { Criterion }\end{array}$ & Description & Criteria & $\begin{array}{l}\text { Scoring } \\
\text { Values }\end{array}$ & $\begin{array}{l}\text { Max } \\
\text { Score }\end{array}$ \\
\hline $\begin{array}{l}\text { Subsurface } \\
\text { Hydrogeology }\end{array}$ & 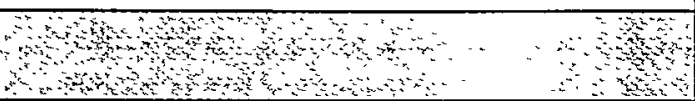 & Nons & sins & 30 \\
\hline $\begin{array}{l}\text { Ground water } \\
\text { depth (Figure 5) }\end{array}$ & $\begin{array}{l}\text { Average groundwater depth and seasonal } \\
\text { fluctuations are considered. The } \\
\text { groundwater variation could affect the } \\
\text { allowable bearing capacity, liquefaction } \\
\text { potential, and the future potential for } \\
\text { groundwater contamination. Potential flow } \\
\text { directions are also considered. High hazard } \\
\text { facilities (PC-3 and higher) require seismic } \\
\text { design analysis for liquefaction and deep } \\
\text { subsidence both depending on ground- } \\
\text { water table depths. Construction may } \\
\text { require deep excavations and dewatering }\end{array}$ & $\begin{array}{l}\text { Less than } 20 \text { feet, } \\
20-40 \text { feet, } \\
\text { greater than } 40 \text { feet }\end{array}$ & $\begin{array}{l}0-5 \\
6-10 \\
11-15\end{array}$ & 15 \\
\hline $\begin{array}{l}\text { Ground water } \\
\text { contamination }\end{array}$ & $\begin{array}{l}\text { The primary consideration of the } \\
\text { subsurface hydrology is the existence of } \\
\text { known groundwater contaminant plumes } \\
\text { and the direction of movement in regard to } \\
\text { the evaluation area. }\end{array}$ & $\begin{array}{l}\text { Near a RCRA } \\
\text { CERCLA waste site } \\
\text { or a potential } \\
\text { contamination flow } \\
\text { path of a known } \\
\text { plume }\end{array}$ & $\begin{array}{l}10-15 \\
4-9 \\
0-3\end{array}$ & 15 \\
\hline Géology & 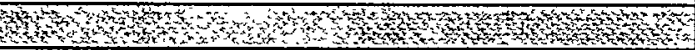 & 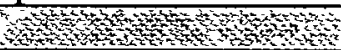 & Why & 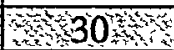 \\
\hline $\begin{array}{l}\text { Known soft } \\
\text { zones and } \\
\text { carbonates }\end{array}$ & $\begin{array}{l}\text { The presence of soft soils (or carbonate } \\
\text { formations) is known to exist at the SRS. } \\
\text { Ground improvement may significantly } \\
\text { increase the construction cost. }\end{array}$ & $\begin{array}{l}\text { Known zones, } \\
\text { possible zones, } \\
\text { no known zones }\end{array}$ & $\begin{array}{l}0-5 \\
6-15 \\
16-20\end{array}$ & 20 \\
\hline $\begin{array}{l}\text { Data confidence } \\
\text { and availability }\end{array}$ & $\begin{array}{l}\text { The number and quality of borings, wells, } \\
\text { CPT's, geophysical data, geographical data } \\
\text { is sufficient to evaluate the subsurface }\end{array}$ & $\begin{array}{l}\text { No subsurface data, } \\
\text { minor subsurface } \\
\text { data, more } \\
\text { subsurface data }\end{array}$ & $\begin{array}{l}0 \\
1-5 \\
6-10\end{array}$ & 10 \\
\hline Sépmology & 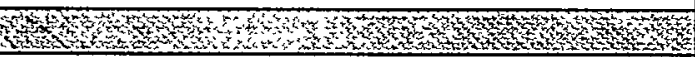 & 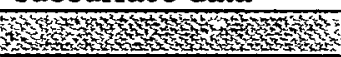 & 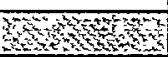 & $\therefore \times 10$ \\
\hline $\begin{array}{l}\text { Proximity to } \\
\text { known fault }\end{array}$ & $\begin{array}{l}\text { The proximity to known faulting affects } \\
\text { both the seismic design criteria and the } \\
\text { potential groundwater effects of the } \\
\text { facility. The expression of faulting as } \\
\text { defined from seismic and well log data is } \\
\text { generally noted from the geophysical } \\
\text { signatures of the regional aquitards. The } \\
\text { shallowest defined regional aquitard is the } \\
\text { Gordon Confining Unit, approximately } 44 \\
\text { to } 47 \text { MYBP. }\end{array}$ & $\begin{array}{l}\text { No fault, fault } \\
\text { within } 1 / 2 \text { mile } \\
\text { does not impact } \\
\text { Gordon Aquitard, } \\
\text { fault within } 1 / 2 \\
\text { mile impacts } \\
\text { Gordon Aquitard }\end{array}$ & $\begin{array}{l}10 \\
9-5 \\
4-0\end{array}$ & 10 \\
\hline
\end{tabular}




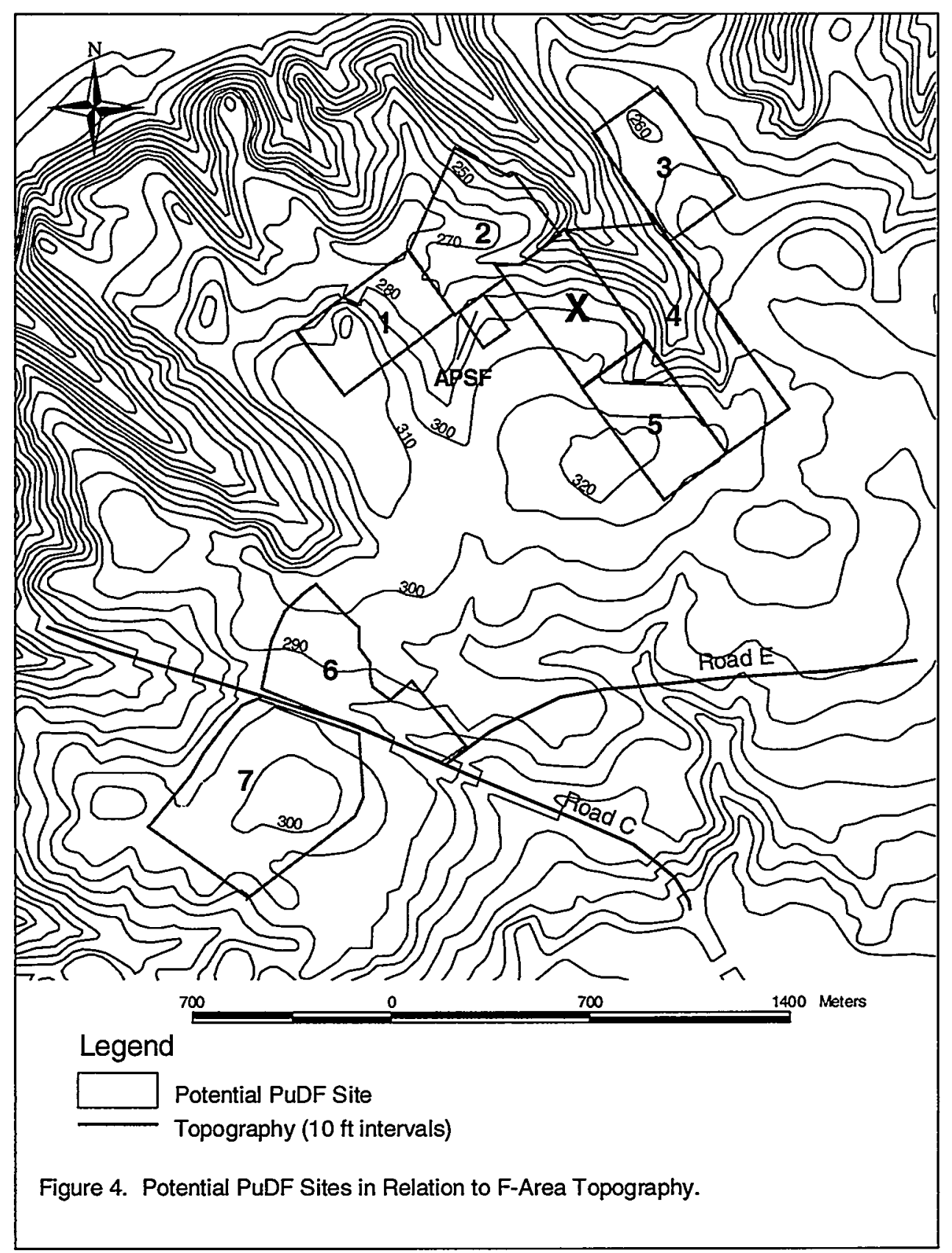




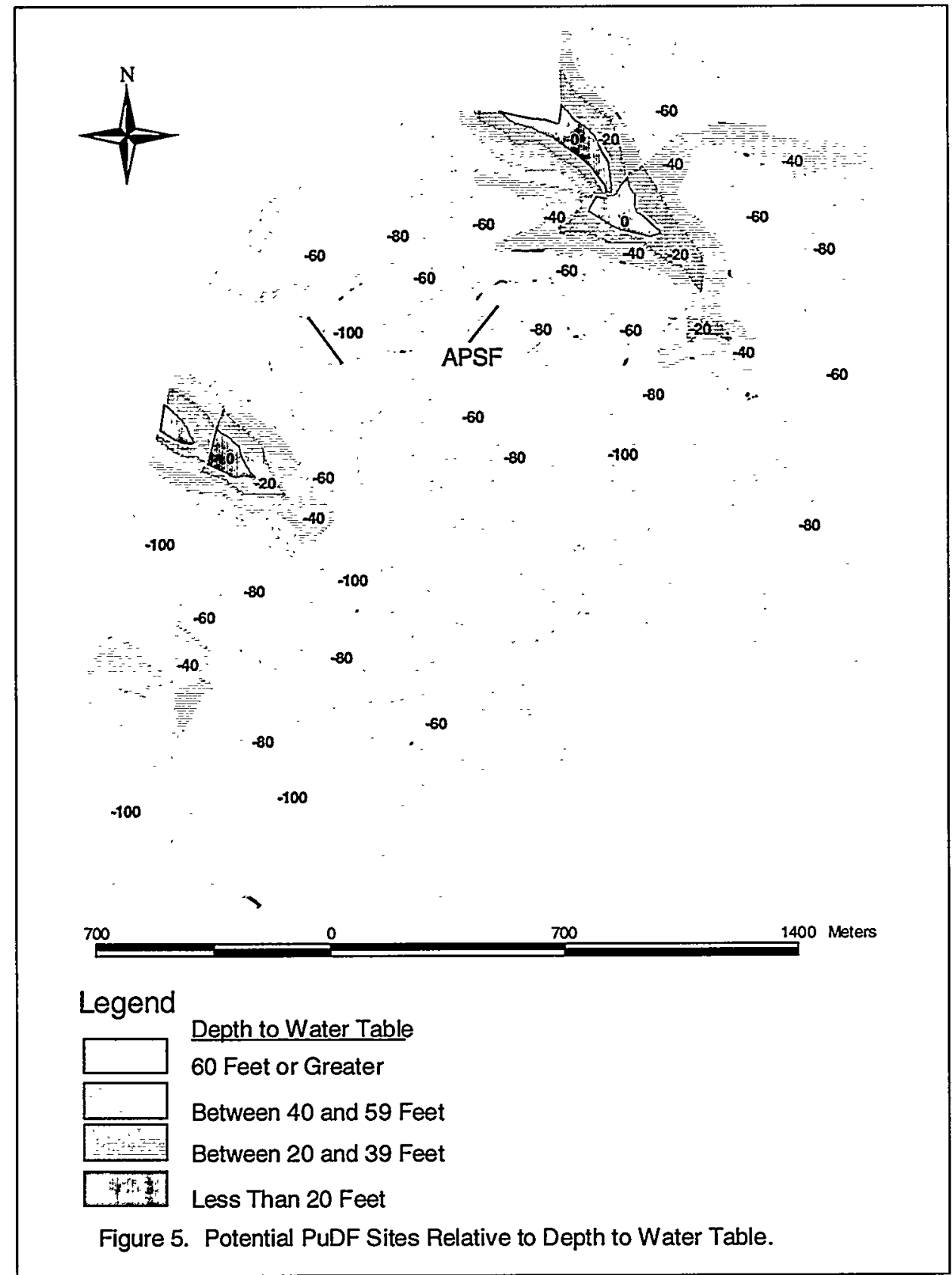




\subsubsection{Engineering}

Distance to F-Canyon tie-in: The candidate sites were evaluated for the distance (based on likely routing) to the closest point to the high level liquid waste tie-in to the east of F Canyon. The facilities were ranked 1-9 with 1 being most distant and 9 being closest to the tie-in point.

Distance to F/H ETF tie-in: The candidate sites were evaluated for the distance (based on likely routing) to the closest point on the Effluent Treatment Facility (ETF) system line to the center of the candidate site. The facilities were ranked 1-9 with 1 being most distant from the ETF system line and 9 being closest.

Disruption to existing infrastructure utilities: "Disruption" considered the need to relocate electric transmission lines, ground water monitoring wells, and other interference to construction of the new facilities caused by the meteorological tower, storm water drainage, the existing ash basin, and impact of construction traffic on existing site traffic patterns. Sites resulting in the least disruption were given the maximum scores with intermediate scores.based on the extent of disruption. The cost of relocation of infrastructure and utilities was the major driver for this rating.

Well relocation - each site's score is equal to the number of monitoring wells likely to require relocation from that site.

Electric transmission line relocation - a score of 1 was awarded for an impact and a score of 6 was awarded to sites with no impact.

Other - each site was evaluated for interferences and the sites were ranked in order of the number of interferences and assigned a score on that basis.

Overall score - each site was given a composite score equal to the sum of the interference component scores. The sites were ranked on the basis of those scores and then assigned an overall score for "Disruption of Existing Utilities" from 1 to 9.

Access to utilities: Each of the candidate sites was assessed for its location relative to most existing utilities and ranked in order of increasing ease of access and given a score of from 1-9 with 1 being most difficult to connect and 9 being easiest to connect to existing utilities. The cost of these new services is directly proportional to the distance to an available tie-in point in an existing line.

Linkage to other new Pu facilities: The scoring for this criterion assumed that MOX and PDCF would remain in their present proposed locations in Sites 2 and X, respectively. The candidate sites were ranked from least centrally located to most centrally located relative to Sites 2 and X. Each site was assigned a score from 1 (most remote) to 9 (closest).

Sanitary plant tie-in: Each candidate site was ranked in two areas: distance to existing sanitary sewer line and elevation. The assumption was that a lower elevation increases the likelihood that a lift station will be needed. Scores were assigned from 1-9 for distance with 1 being farthest and 9 being closest to the existing sewer line. 
Scores from 1-9 were then assigned to each site for elevation with 1 being the lowest and 9 the highest elevation. The two scores were summed for each site and the sites ranked by their composite score. The sites were assigned an overall score from 1-9 with 1 being the lowest composite score and 9 the highest.

The scoring for this subcategory is the cost of sanitary tie-in line, which is directly proportional to the distance to existing treatment facility lines.

Proximity to NPDES outfall: The candidate sites were evaluated for their distance (based on likely routing) to the closest National Pollutant Discharge Elimination System (NPDES) outfall. The assumption being that the closer a site is to an existing outfall, the less expensive the tie-in. The facilities were ranked 1-9 with 1 being most distant and 9 being closest to an existing outfall.

Construction equipment access: Each candidate site was evaluated on the degree of difficulty anticipated in bringing large-scale construction equipment from an existing site primary road. The sites were ranked in order of decreasing difficulty of site access by construction equipment and assigned scores with 1 being most difficult to access and 9 possessing the easiest access.

Suitability of construction site: Each candidate site was evaluated on the basis of cost effectiveness attributes including: separation of the construction site from existing operating facilities; the availability of approximately 20 acres of laydown area adjacent to or in close proximity to the construction site for material storage, equipment access, and excess soil disposal from excavations. The sites were ranked on the basis of these attributes and a score of 9 was assigned to the site with the best suitability to use as a construction site and 1 to the site found least suitable.

Proximity to primary road and rail: This subcategory considers proximity to existing SRS road and rail infrastructure to provide personnel access and material deliveries, during both construction and long-term facility operation. The cost of providing this infrastructure is directly proportional to the distance to existing roads and rail (Figure 6).

Each candidate site was evaluated separately for its proximity to an existing site primary road and rail line or spur. The sites were ranked two times in order of increasing distance to each and a score assigned to each site with 1 being most distant and 9 being closest. The two scores were added and the sites ranked highest to lowest based on the composite scores. The site's rank was based on the composite with a score of 9 for the site with the best access to both a primary road and rail line and 1 for the worst access.

Archeology: Evaluations of each site were made by members of Savannah River Archaeological Research Program based on best professional judgment as supported by information in King and Stephenson (2000).

Safeguards and security: Scoring of the nine candidate sites was done on the basis of the time that it would take WSI responders to arrive at the facilities from their normal posts and engage an adversary attempting to enter the facility. The highest 
ranking was given to sites that could be reached by the largest number of WSI responders in the least amount of time. Candidate sites that would take the longest time to reach were ranked lowest. The sites were assigned scores on the basis of their ranking with a score of 9 for the shortest response time and 1 for the longest. 


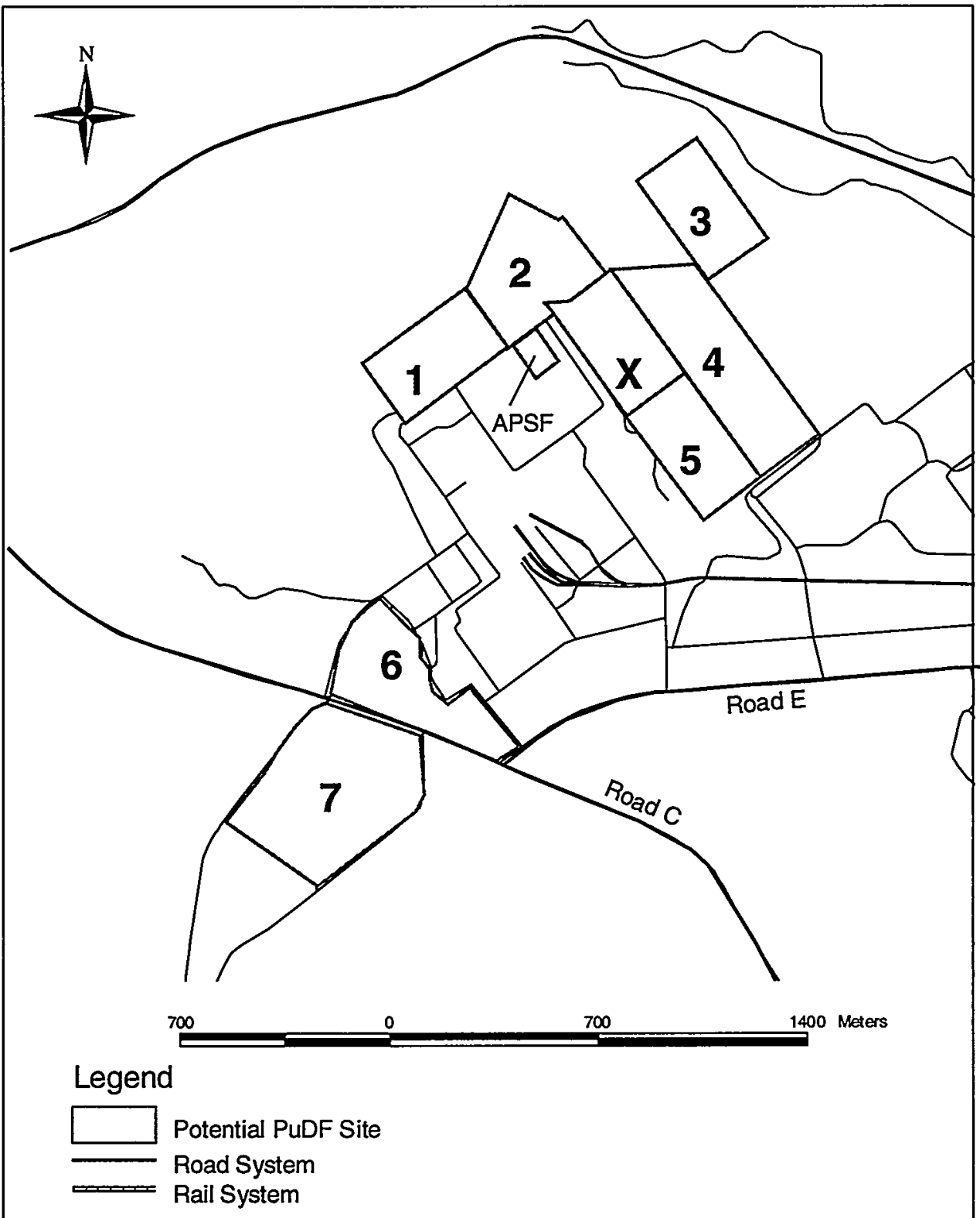

Figure 6. Potential PuDF Sites in Relation to F-Area Road and Rail Systems. 


\subsection{Scoring of Candidate Sites}

Table 2. Summary of Scoring for PuDF Candidate Sites

\begin{tabular}{|c|c|c|c|c|c|c|c|c|c|c|c|c|}
\hline Category & Weight & Criteria & Weight & $\begin{array}{c}\text { Site } \\
1 \\
\end{array}$ & $\begin{array}{c}\text { Site } \\
\mathbf{2} \\
\end{array}$ & $\begin{array}{c}\text { Site } \\
3 \\
\end{array}$ & $\begin{array}{c}\text { Site } \\
4 \\
\end{array}$ & $\begin{array}{c}\text { Site } \\
5 \\
\end{array}$ & $\begin{array}{c}\text { Site } \\
6 \\
\end{array}$ & $\begin{array}{c}\text { Site } \\
7 \\
\end{array}$ & $\begin{array}{c}\text { Site } \\
\mathbf{X}\end{array}$ & $\begin{array}{c}\text { APS } \\
\mathbf{F}\end{array}$ \\
\hline \multirow[t]{6}{*}{ Ecology } & 10 & & & & & & & & & & & \\
\hline & & Terrestrial & 20 & 20 & 20 & 15 & 15 & 20 & 20 & 20 & 20 & 20 \\
\hline & & Wetlands & 30 & 30 & 30 & 20 & 20 & 30 & 30 & 30 & 30 & 30 \\
\hline & & Aquatic & 50 & 50 & 30 & 25 & 25 & 50 & 50 & 30 & 50 & 50 \\
\hline & & Total & & 100 & 80 & 60 & 60 & 100 & 100 & 80 & 100 & 100 \\
\hline & & Weighted Total & & 10 & 8 & 6 & 6 & 10 & 10 & 8 & 10 & 10 \\
\hline \multirow[t]{7}{*}{$\begin{array}{l}\text { Human } \\
\text { Health } \\
\end{array}$} & 25 & & & & & & & & & & & \\
\hline & & Risk to Offsite Population & 20 & 20 & 20 & 20 & 20 & 20 & 20 & 20 & 20 & 20 \\
\hline & & Effect on Workers in Nearby Facilities & 20 & 20 & 20 & 20 & 20 & 20. & 20 & 20 & 20 & 20 \\
\hline & & $\begin{array}{l}\text { Effect on PuDF Workers from Nearby } \\
\text { Facilities }\end{array}$ & 20 & 17 & 20 & 20 & 20 & $20^{\circ}$ & 16 & 20 & 19 & 15 \\
\hline & & Emergency Response/Preparedness & 40 & 35 & 35 & 30 & 35 & 35 & 25 & 25 & 35 & 35 \\
\hline & & 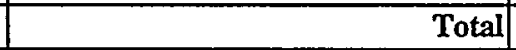 & & 92 & 95 & 90 & 95 & 95 & 81 & 85 & 94 & 90 \\
\hline & & Weighted Total & & 23.0 & 23.8 & 22.5 & 23.8 & 23.8 & 20.3 & 21.3 & 23.5 & 22.5 \\
\hline \multirow[t]{8}{*}{ Geoscience } & 30 & & & & & & & & & & & \\
\hline & & Topography & 15 & 10 & 9 & 11 & 6 & 7 & 11 & 9 & 10 & 13 \\
\hline & & Surface Hydrology & 15 & 14 & 13 & 14 & 13 & 13 & 15 & 13 & 14 & 15 \\
\hline & & Subsurface Hydrology & 30 & 18 & 25 & 20 & 5 & 18 & 15 & 23 & 23 & 21 \\
\hline & & Geology & 30 & 8 & 11 & 11 & 8 & 10 & 13 & 13 & 13 & 16 \\
\hline & & Seismology & 10 & 6 & 6 & 6 & 6 & 6 & 6 & 6 & 6 & 6 \\
\hline & & Total & & 56 & 64 & 62 & 38 & 54 & 60 & 64 & 66 & 71 \\
\hline & & Weighted Total & & 16.8 & 19.2 & 18.6 & 11.4 & 16.2 & 18.0 & 19.2 & 19.8 & 21.3 \\
\hline \multirow[t]{15}{*}{ Engineering } & 35 & & & & & & & & & & & \\
\hline & & Distance to $\mathrm{F} / \mathrm{H}$ Canyon tie-in & 12 & 10.8 & 8.4 & 3.6 & 4.8 & 6.6 & 2.4 & 1.2 & 6.6 & 9.6 \\
\hline & & Distance to ETF tie-in & 8 & 7.2 & 5.6 & 0.8 & 1.6 & 2.4 & 6.4 & 4.8 & 3.2 & 4 \\
\hline & & $\begin{array}{l}\text { Disruption to existing } \\
\text { infrastructure/utilities }\end{array}$ & 7 & 3.5 & 4.2 & 4.9 & 1.4 & 5.6 & 2.1 & 4.2 & 2.8 & 6.3 \\
\hline & & $\begin{array}{l}\text { Access to utilities (operations and } \\
\text { construction) }\end{array}$ & 12 & 10.8 & 7.8 & 1.2 & 4.8 & 6 & 3.6 & 1.2 & 7.8 & 9.6 \\
\hline & & Linkage to other new $\mathrm{Pu}$ facilities & 6 & 3 & 4.2 & 1.8 & 3.6 & 2.4 & 1.2 & 1.2 & 5.4 & 4.8 \\
\hline & & Sanitary plant tie-In & 8 & 7.2 & 1.6 & 3.2 & 0.8 & 5.6 & 6.4 & 4 & 4.8 & 2.4 \\
\hline & & Proximity to NPDES outfall & 5 & 2 & 4.5 & 0.5 & 3 & 2.5 & 1.5 & 2.5 & 3.5 & 4 \\
\hline & & Construction equipment access & 5 & 3.5 & 3 & 0.5 & 1 & 2.25 & 4 & 3.5 & 2.25 & 1.5 \\
\hline & & Suitability of construction site & 12 & 6.6 & 8.4 & 3.6 & 6.6 & 4.8 & 10.8 & 10.8 & 9.6 & 1.2 \\
\hline & & Proximity to primary road and rail & 8 & 4 & 2.8 & 0.8 & 4.8 & 5.6 & 6.8 & 1.6 & 2.8 & 2.8 \\
\hline & & Archaeology & 2 & 2 & 0 & $\begin{array}{ll}0 \\
0\end{array}$ & 2 & 2 & 1 & 1 & $\begin{array}{l}0 \\
0\end{array}$ & 2 \\
\hline & & Safeguards and security & 15 & 10.5 & 9 & 3.75 & 6 & 7.5 & 3.75 & 3 & 10.5 & 10.5 \\
\hline & & Total & & 71.1 & 59.5 & 24.7 & 40.4 & 53.3 & 50.0 & 39.0 & 59.3 & 58.7 \\
\hline & & Weighted Total & & 24.9 & 20.8 & 8.6 & 14.1 & 18.6 & 17.5 & 13.7 & 20.7 & 20.5 \\
\hline & & & & & & & & & & & & \\
\hline Total & & & & 74.7 & 71.8 & 55.7 & 55.3 & 67.7 & 65.7 & 62.1 & 74.0 & 74.3 \\
\hline Rank & & & & 1 & 4 & 8 & 9 & 5 & 6 & 7 & 3 & 2 \\
\hline
\end{tabular}




\subsection{Scoring of Candidate Sites}

Scoring of candidate sites was conducted based on the site lay-outs presented in Figure 1 and subsequent figures, with the exception of Site 1 . The presence of the process sewer line through the original proposed location for Site 1 necessitated a minor relocation of that site to the west, as shown by the inset in Figure 1. Scoring of Site 1 is based on the placement depicted in the Figure 1 inset.

\subsubsection{Ecology}

Terrestrial Ecology: All candidate sites except Sites 3 and 4 scored the maximum of 20 points for terrestrial ecology (Table 1). Sites 3 and 4 are partially vegetated with mature hardwoods, which are a higher value resource than the pine plantation and disturbed areas of the other sites.

Wetlands: Sites 3 and 4 received less than maximum points because they are closer to the nearest delineated wetlands than the other sites and therefore have greater potential for impact upon these areas. All other sites received maximum scores.

Aquatic Ecology: Except for Sites 6 and 7, all other sites are within the Upper Three Runs drainage. Upper Three Runs is an important ecological resource at SRS and is a contributor to regional biodiversity. Sites 3 and 4 have the greatest potential to negatively impact Upper Three Runs and are therefore ranked the lowest. Site 2, because of its location, is slightly less likely to cause impact within the drainage and, as such, scores somewhat higher. Sites 1, 5, X, and APSF are all far enough upland from stream tributaries that their potential impacts are the least of all sites. Sites 6 and 7 are within the Fourmile Branch drainage. Site 6 is sufficiently upland that it has little potential for impact upon the Fourmile drainage. Site 7 is much closer to Fourmile Branch and as such scores slightly lower than Site 6.

\subsubsection{Human Health}

The evaluation of factors potentially affecting human health was based on the consequences of a radiological release from the $\mathrm{PuDF}$ at the proposed location to either offsite populations or workers at the nearest onsite facility, or the consequences of a release from a nearby facility on workers at the PuDF (Lee, 2000: Appendix A). These analyses were based on calculations of the relative doses associated with the events, which is a function of the proximity of other facilities, the potential releases associated with those facilities, and prevailing wind directions at the SRS. Of the suitability of the nine sites with respect to emergency preparedness considerations, evaluations were based on evaluation of aerial photography and ground-level analyses of the relative ease of access to, and egress from, the PuDF during emergency conditions. The locations of the $\mathrm{PuDF}$ sites and onsite worker populations and potential release sources are shown in Figure 3.

\section{Site 1}

The proposed PuDF Site 1 was given the maximum score of 20 for risk to offsite populations because it is centrally located with respect to the site boundary. Site 1 scored 17 of a possible 20 points for risk to the non-PuDF worker. Its proximity to Building 717-14F yielded a higher dose to the onsite worker relative to doses received 
by the nearest workers from the other proposed sites. Site 1 received the maximum score of 20 points for risk to potential PuDF workers from exposure to releases from a nearby facility (i.e., 291-F Canyon Stack). Its proximity to the 291-F Canyon Stack and the prevailing winds yielded a dose similar to that of other eight sites evaluated. Site 1 received 35 out of the maximum score (40) for emergency response. It was downgraded in scoring because of the lack of a major access road. leading to the site. The total raw score awarded for the Human Health category for Site 1 was 92.

\section{Site 2}

Like Site 1, the proposed PuDF Site 2 was given the maximum score of 20 for risk to offsite populations because it is centrally located with respect to the site boundary. Site 2 scored the maximum 20 points for risk to the non-PuDF worker. Its proximity to Building 247-F yielded an onsite worker dose similar to that of other eight sites evaluated. Similarly, Site 2 received the maximum score of 20 points for risk to potential workers at that site from exposure to releases from the 291-F Canyon Stack. Its proximity to that facility and the prevailing winds yielded a dose similar to that of the other eight sites evaluated. Like Site 1 , Site 2 received 35 out of the maximum score (40) for emergency response. It was also downgraded in scoring because of the lack of a major access road leading to the site. The total raw score of 95 for Site 2 was amongst the highest scores awarded for the Human Health category of the nine sites evaluated.

\section{Site 3}

Like Sites 1 and 2; the proposed PuDF Site 3 was given the maximum score of 20 for risk to offsite populations because it is centrally located with respect to the site boundary. Like Site 2, Site 3 scored the maximum 20 points for risk to the non-PuDF worker due to its proximity to Building 247-F. Like Sites 1 and 2, Site 3 received the maximum score of 20 points for risk to the potential PuDF worker at that site from exposure to releases from the 291-F Canyon Stack due to its proximity to that facility and the prevailing winds. Site 3 graded out as 30 out of a possible 40 points based on the lack of a major access road and the increased distance (compared to the other proposed sites) for emergency response (Mathews, 2000). The total raw score awarded for Human Health for Site 3 was the 90.

\section{Site 4}

Like Sites 1, 2, and 3, the proposed PuDF Site 4 was given the maximum score of 20 for risk to offsite populations because it is centrally located with respect to the site boundary. Site 4 scored the maximum 20 points for risk to the non-PuDF worker due to its proximity to Building 701-16F. Like Sites 1,2 , and 3 , Site 4 received the maximum score of 20 points for risk to the potential PuDF worker from exposure to releases from the 291-F Canyon Stack due to its proximity to that facility and the prevailing winds. Like Sites 1 and 2, Site 4 received 35 out of the maximum score (40) for emergency response. It was also downgraded in scoring because of the lack of a major access road leading to the site. The total raw score for Site 4 was 95 and equaled the score for Site 2 . The total raw score of 95 for Site 4 was among the highest score awarded for the Human Health category of the nine sites evaluated. 
Site 5

The proposed PuDF Site 5, like the others, was given the maximum score of 20 for risk to offsite populations because it is centrally located with respect to the site boundary. Site 5, like Site 4 scored the maximum 20 points for risk to the non-PuDF worker due to its proximity to Building 701-16F. Similarly, Site 5 received the maximum score of 20 points for risk to the potential PuDF worker at that site from exposure to releases from the 291-F Canyon Stack due to its proximity to that facility and the prevailing winds. Like Sites 1,2 , and 4, Site 5 received 35 out of the maximum score (40) for emergency response. It was also downgraded in scoring because of the lack of a major access road leading to the site. The total raw score of 95 for Site 5 was amongst the highest score awarded for the Human Health category of the nine sites evaluated.

\section{Site 6}

Like the other sites, the proposed PuDF Site 6 was given the maximum score of 20 for risk to offsite populations because it is centrally located with respect to the site boundary. Site 6 scored 16 of a possible 20 points for risk to the non-PuDF worker. Its proximity to the construction area yielded a higher dose to the onsite worker relative to doses received by the nearest workers to many of the other proposed sites. Like Sites 1, 2, 3, 4 and 5, Site 6 received the maximum score of 20 points for risk to the potential PuDF worker from exposure to releases from the 291-F Canyon Stack due to its proximity to that facility and the prevailing winds. Site 6 received 25 out of the maximum score (40) for emergency preparedness because of its proximity to the water treatment plant. Because the water treatment plant is considered to be a critical service that could not be staffed and operated in the event of an emergency occurrence, its proximity must be taken into account. Its predominantly upwind direction from $\mathrm{F}$ Area increases the potential to impact not only F Area but also the only existing major road in and out of the area if an event should occur. The advantage of a nearby major access road (SRS Road C) is a liability for this site because SRS Road $\mathrm{C}$ is the only existing major road in the area and impacts to that route during an event could have extensive negative impacts on other site operations. The total raw score for Site 6 was 81, the lowest score awarded for the Human Health category among the nine sites evaluated.

\section{Site 7}

Like the other sites, the proposed PuDF Site 7 was given the maximum score of 20 for risk to offsite populations because it is centrally located with respect to the site boundary. Site 7 scored the maximum 20 points for risk to the non-PuDF worker due to its proximity to Building 701-17F. Like the other proposed sites, Site 7 received the maximum score of 20 points for risk to the potential PuDF worker from exposure to releases from the 291-F Canyon Stack due to its proximity to that facility and the prevailing winds. Site 7 received 25 out of the maximum score (40) for emergency preparedness because of its proximity to the water treatment plant. Because the water treatment plant is considered to be a critical service that could not be staffed and operated in the event of an emergency occurrence, its proximity must be taken into account. Its predominantly upwind direction from $\mathrm{F}$-Area increases the potential to impact not only F-Area but also the only existing major road in and out of the area if an event should occur. The advantage of a nearby major access road (SRS Road C) is a liability for this site because SRS Road C is the only existing major road in the area 
and impacts to that route during an event could have extensive negative impacts on other site operations. The total raw score of 85 for Site 7 was the second lowest score awarded for the Human Health category among the nine sites evaluated.

Site X

The proposed PuDF Site $X$ was given the maximum score of 20 for risk to offsite populations because it is centrally located with respect to the site boundary. Site $\mathrm{X}$ scored 19 of a possible 20 points for risk to the non-PuDF worker. Its proximity to the Building 247-F yielded a somewhat higher dose to the onsite worker relative to doses received by the nearest workers to many of the other proposed sites. Like the others, Site $\mathrm{X}$ was given the maximum score of 20 points for risk to the potential PuDF worker from exposure to releases from the 291-F Canyon Stack due to its proximity to that facility and the prevailing winds. Like Sites 1,2,4 and 5, Site X received 35 out of the maximum score (40) for emergency response. It was also downgraded in scoring because of the lack of a major access road leading to the site. The total raw score of 94 for Site X was the second highest score awarded for the Human Health category among the nine sites evaluated.

\begin{abstract}
APSF Site
Like the other sites, the proposed PuDF APSF Site was given the maximum score of 20 for risk to offsite populations because it is centrally located with respect to the site boundary. The APSF Site scored 15 of 20 possible points for risk to the non-PuDF worker. Its close proximity to the Building $235-11 \mathrm{~F}$ yielded a higher dose to the onsite worker relative to doses received by the nearest workers to many of the other proposed sites. The APSF Site received the maximum of 20 points for risk to potential PuDF workers from exposure to releases from the 291-F Canyon Stack. Its proximity to the 291-F Canyon Stack and the prevailing winds yielded a dose similar to that of other eight sites evaluated. Like Sites $1,2,4,5$, and X, the APSF Site received 35 out of the maximum score (40) for emergency response. It was also downgraded in scoring because of the lack of a major access road leading to the site. The total raw score awarded for the Human Health for the APSF Site was 90.
\end{abstract}

\title{
4.2.3 Geoscience
}

Proposed PuDF Sites $1,2,3,4,5,6,7, \mathrm{X}$ and the APSF site were reviewed using the geoscience criteria defined below. The geoscience criteria were evaluated utilizing data from regional monitoring wells, historical geotechnical and geological borings, historical cone penetrometer test soundings and regional geological and geophysical knowledge. Table 3 provides a summary of scores by site and specific criterion. The following text presents narrative summaries of geotechnical evaluations of each of the nine sites.

\section{Site 1}

Site 1 is located along the northwest boundary of F Area. The overall orientation of the site trends southwest to northeast, approximately aligned with SRS east-west. Historically, the site was used as a parking and laydown area for F-Area construction activities. Prior to SRS, the area was in agricultural use. The northern portion of the site contains the Old F-Area Seepage Basin waste unit, process sewer line, and associated contaminant plume which is in the final stages of a RCRA closure. The site 
is situated along a topographic high, which is underlain by sediments of the Upland Unit. Surficial soils are generally Udorthents (disturbed soils) or Blanton Sands (BaB). The overall topography for Site 1 has been graded relatively flat along the southern half of the site due to historical construction in the area. The northern or northwestern portion and eastern portion of the site descends topographically towards tributaries of Upper Three Runs. There is a small topographic high located in the center of the site. Locally, there are small areas that drain less quickly than other areas but the natural drainage at the facility footprint is good. The area may need to be graded flat because of the topographical change across the site. Minor road or rail profiles may need to be constructed because of the topographical relief across the site. Site 1 does not lie within the 100-year floodplain nor has there been localized flooding. The groundwater depth at Site 1 is greater than 60 feet deep. The Site 1 footprint is hydrogeologically downgradient from potential plumes emanating from the F-Canyon area. There are possible soft zones and carbonates underlying the site based on nearby data. There are no known faults within one-half mile of the footprint that disrupt the Gordon Aquitard although deeper faulting is suspected. There is only one boring or monitoring well point within the Site 1 footprint although there are a few surrounding subsurface data points.

Table 3. Geoscience criteria scoring summary.

\begin{tabular}{|l|c|c|c|c|c|c|c|c|c|c|}
\hline & Maximum & Site 1 & Site 2 & Site 3 & Site 4 & Site 5 & Site 6 & Site 7 & Site X & APSF $^{\text {a }}$ \\
\hline Topography & 15 & 10 & 9 & 11 & 6 & 7 & 11 & 9 & 10 & 13 \\
\hline Site topography & 3 & 2 & 1 & 2 & 0 & 1 & 3 & 2 & 2 & 3 \\
\hline Natural drainage, site & 3 & 3 & 3 & 3 & 3 & 2 & 1 & 1 & 2 & 3 \\
\hline Natural drainage, facility footprint & 3 & 2 & 2 & 2 & 2 & 2 & 2 & 2 & 2 & 2 \\
\hline Balanced cut and fill & 3 & 1 & 1 & 2 & 0 & 0 & 3 & 2 & 2 & 3 \\
\hline Road and rail profiles & 3 & 2 & 2 & 2 & 1 & 2 & 2 & 2 & 2 & 2 \\
\hline Surface Hydrology & 15 & 14 & 13 & 14 & 13 & 13 & 15 & 13 & 14 & 15 \\
\hline Proximity to floodplain & 10 & 10 & 10 & 10 & 8 & 10 & 10 & 10 & 10 & 10 \\
\hline Local flooding & 5 & 4 & 3 & 4 & 5 & 3 & 5 & 3 & 4 & 5 \\
\hline Subsurface Hydrology & 30 & 18 & 25 & 20 & 5 & 15 & 15 & 23 & 23 & 21 \\
\hline Ground water depth & 15 & 15 & 12 & 12 & 2 & 15 & 15 & 14 & 11 & 10 \\
\hline Ground water contamination & 15 & 3 & 13 & 8 & 3 & 0 & 0 & 9 & 12 & 11 \\
\hline Geology & $\mathbf{3 0}$ & $\mathbf{8}$ & $\mathbf{1 1}$ & $\mathbf{1 1}$ & $\mathbf{8}$ & $\mathbf{1 0}$ & $\mathbf{1 3}$ & 13 & 13 & 16 \\
\hline Soft Zones and Carbonates & 20 & 6 & 6 & 7 & 6 & 6 & 9 & 9 & 6 & 6 \\
\hline Data Confidence/Availability & 10 & 2 & 5 & 4 & 2 & 4 & 4 & 4 & 7 & 10 \\
\hline Seismology & $\mathbf{1 0}$ & $\mathbf{6}$ & $\mathbf{6}$ & $\mathbf{6}$ & $\mathbf{6}$ & $\mathbf{6}$ & $\mathbf{6}$ & $\mathbf{6}$ & $\mathbf{6}$ & $\mathbf{6}$ \\
\hline Geoscience raw score & $\mathbf{1 0 0}$ & $\mathbf{5 6}$ & $\mathbf{6 4}$ & $\mathbf{6 2}$ & $\mathbf{3 8}$ & $\mathbf{5 4}$ & $\mathbf{6 0}$ & $\mathbf{6 4}$ & $\mathbf{6 6}$ & $\mathbf{7 1}$ \\
\hline IIt is assumed that the APSF excavation will be backfilled for its score to be comparable to the other sites. & & \\
\hline
\end{tabular}


Site 2

Site 2 is located due north of F Area and adjacent to the F-Area facilities. The overall orientation of the site trends west-southwest although the site is irregular in boundary. Historically, the site was used as a spoils pile area for F-Area construction activities, most recently the APSF excavation. Prior to SRS, the area was in agricultural use, sloping into northwestward into wooded lowlands. The site is underlain by sediments of the Upland Unit. Surficial soils are generally Blanton sands $(\mathrm{BaB})$ or soils of the Vaucluse-Ailey association (VeD).

Site 2 is sloped to the northwest and to the south defining a topographic "nose". Locally, there are small areas that drain less quickly than other areas but the natural drainage at the facility footprint is generally good, however, preferred drainage paths have been noted. Because of the slope, cut and fill requirements are nominal. There are considerations for road or rail profiles because of the topography. Site 2 does not lie within the 100-year floodplain nor has there been localized flooding. The groundwater depth at Site 2 varies between 40 and 60 feet. The site is hydrogeologically downgradient from potential contaminants emanating from the F Canyon areas. There are possible soft zones and carbonates underlying the site based on nearby data. There are no known faults within one-half mile of the footprint that disrupt the Gordon Aquitard although deeper faulting is suspected. There are many existing boring data points in the western portion of the site and several CPT data points located in the southern and eastern portion of the site.

\section{Site 3}

Site 3 is located approximately 1500 feet northeast of F Area and adjacent to the Burial Ground Expansion Area. The overall orientation of the site trends northwest, approximately aligned with SRS north. Historically, the site was used as a borrow pit. Prior to SRS, the area was in agricultural or woodland use, grading westward into wetland and woodland. The site is situated along the central to western flank of a topographic high, which is underlain by sediments of the Upland Unit. Surficial soils are generally Lakeland sands (LaB) or Ailey sands (AeD).

The overall topography for Site 3 has been modified due to historical borrow construction in the area. Locally, there are small areas that drain less quickly than other areas but the natural drainage at the facility footprint is good. There are fill requirements for the borrow area. Because of the topographical variation across the site, there are road or rail profile considerations. Site 3 does not lie within the 100 -year floodplain nor has there been localized flooding. The groundwater depth at Site 3 varies between 20 and 40 feet. The Site 3 footprint is hydrogeologically downgradient from potential plumes emanating from the Mixed Waste Management Facility. There are possible soft zones and carbonates underlying the site based on nearby data. There are no known faults within one-half mile of the footprint that disrupt the Gordon Aquitard although deeper faulting is suspected. There are several borings data points located across Site 3 interspersed with a few CPT data points.

\section{Site 4}

Site 4 is located approximately 900 feet east of the F-Area boundary and approximately 300 feet northwest of the Mixed Waste Management Facility. The overall orientation of the site trends northwest, approximately aligned with SRS north. 
Historically, the site has been a wetland and woodland. Currently, the site is a wetland drainage and woodland and is the principal drainage tributary along the eastern side of F Area. The site is a topographic low and drainage underlain by sediments of the Upland Unit and Tobacco Road Formation. Surficial soils are mostly of VaucluseAiley (VeD) composition.

Site 4 is a topographical low that is a tributary draining northwards toward Upper Three Runs. Locally, there are small areas that drain less quickly than other areas but the natural drainage at the facility footprint is generally good. However, after heavy rains localized ponding, seepage and increased stream flow has been noted. Because of the change in slope, the cut and fill requirements are great. There are road or rail construction considerations. Site 4 does not lie within the 100-year floodplain nor has there been localized flooding. The groundwater depth at Site 4 is less than 20 feet. The site is hydrogeologically downgradient from potential contaminants from the F-Area NPDES discharges and from the Burial Ground Expansion Area and the Mixed Waste Management Facility. There are possible soft zones and carbonates underlying the site based on nearby data. There are no known faults within one-half mile of the footprint that disrupt the Gordon Aquitard although deeper faulting is suspected.

Site 5

Site 5 is located approximately 600 feet west of the F-Area boundary and immediately northwest of the Mixed Waste Management Facility. The overall orientation of the site trends northwest-southeast. Historically, the site was used as a debris or spoils pile location. Currently, the site contains an active ash disposal baisin. Prior to SRS, the area was in agricultural use. The site slopes from a topographic high in the westward portion to a drainage in the northeastern portion of the site. The site is underlain by sediments of the Upland Unit. Surficial soils are generally Udorthents (disturbed soils).

Site 5 has a minor slope in the northeastern portion dipping eastward towards a tributary of Upper Three Runs. Locally, there are small areas that drain less quickly than other areas and the natural drainage at the facility footprint is nominal. Because of the debris piles and ash basin, the cut and fill requirements are considerable. There are no road or rail profiles of any consequence. Site 5 does not lie within the 100-year floodplain nor has there been localized flooding. The groundwater depth at Site 5 is generally greater than 60 feet. The site is hydrogeologically downgradient from potential contaminants emanating from the Mixed Waste Management Facility and may contain contaminants from the ash basin. Elevated levels of tritium and possibly trichloroethylene (TCE) are found in wells immediately up-gradient to and potentially projecting through the site. There are known soft zone carbonates underlying the footprint based on existing subsurface data near the area and carbonates have been mapped in adjacent areas. There are no known faults within one-half mile of the footprint that disrupt the Gordon Aquitard. There are several CPT data locations and monitoring wells located within the site.

Site 5 was not excluded from consideration because the ash basin is not considered a "high risk" waste site and the underlying contaminated groundwater plume lies well below the construction envelope of the proposed facilities. 
Site 6

Site 6 is located approximately 1500 feet west/southwest of the F Area boundary. The overall orientation of the site trends northwest/southeast although the site boundary is irregular. Historically, the site was used as a wooded buffer area between F-Area operations and SRS Road C. Prior to SRS, the area was in agricultural use. The site is underlain by sediments of the Upland Unit. Surficial soils are generally Udorthents (disturbed).

Site 6 has a minor slope dipping southeastward towards a tributary of Fourmile Branch. Locally, there are small areas that drain less quickly than other areas and the natural drainage at the facility footprint is nominal. Because of the minor slope, the cut and fill requirements are minimal. There are no road or rail profiles of any consequence. Site 6 does not lie within the 100-year floodplain nor has there been localized flooding. The groundwater depth at Site 6 is generally 40 to 60 feet. The site is hydrogeologically downgradient from potential contaminants emanating from the $F$ Canyon and F-Area Tank Farm. Elevated levels of tritium are known in the groundwater of the site. There are possible soft zones and carbonates underlying the site based on nearby data. There are no known faults within one-half mile of the footprint that disrupt the Gordon Aquitard although deeper faulting is suspected.

Site 7

Site 7 is located approximately 2500 feet west/southwest of F Area and west of SRS Road C. The overall orientation of the site trends west/southwest and the boundary is irregular. Historically, the site was used as a borrow pit and presently contains the Burma Road Rubble Pile Waste Unit. Prior to SRS, the area was in agricultural and woodland use. The site is situated along a topographic high, which is underlain by sediments of the Upland Unit. Surficial soils are generally Udorthents (disturbed soils) or soils of the Ailey (Aeb) and Dothan DoB) sands.

Site 7 generally has radial drainage. Locally, there are small areas that drain less quickly than other areas but the natural drainage at the facility footprint is generally good. Because of the borrow pit, the cut and fill requirements are considerable. There are no road or rail profiles of any consequence. Site 7 does not lie within the 100-year floodplain nor has there been localized flooding. The groundwater depth at Site 7 is approximately 40 to 60 feet. The site may contain groundwater contamination from the Burma Road waste unit. There are possible soft zones and carbonates underlying the site based on nearby data. There are no known faults within one-half mile of the footprint that disrupt the Gordon Aquitard although deeper faulting is suspected. There are several monitoring wells within the northern portion of the site associated with the Burma Road waste unit.

\section{Site X}

Site $\mathrm{X}$ is located immediately west of, and adjacent to, $\mathrm{F}$ Area. The overall orientation of the site trends northwest/southeast approximately aligned with SRS north.

Historically, the site was used as a laydown area for F-Area construction activities. Prior to SRS, the area was in agricultural use, sloping eastward and northeastward into wooded lowlands. The site is situated along an eastward slope of a topographic high, which is underlain by sediments of the Upland Unit. Surficial soils are generally Udorthents (disturbed soils) or soils of the Blanton sand $(\mathrm{BaB})$. 
Site X has a slope dipping eastward towards a tributary of Upper Three Runs. Locally, there are small areas that drain less quickly than other areas but the natural drainage at the facility footprint is generally good. Because of the slope, the cut and fill requirements are nominal. There are no road or rail profiles of any consequence. Site $\mathrm{X}$ does not lie within the 100-year floodplain nor has there been localized flooding. The groundwater depth at Site $\mathrm{X}$ is varies between 20 and 60 feet, depending on the topographic elevation. The site is hydrogeologically sidegradient from potential contaminants emanating from F Area. There are possible soft zones and carbonates underlying the site, based on nearby data and site-specific exploration (WSRC, 1999). There are no known faults within one-half mile of the footprint that disrupt the Gordon Aquitard although deeper faulting is suspected. There are several CPT data locations within the site.

\section{APSF Site}

The APSF Site is located within the F-Area boundary and northward from the F Area processing facilities. The overall orientation of the site trends northwest-southeast approximately aligned with SRS north. Historically, the site was used as a laydown area for F-Area construction activities. Prior to SRS, the area was in agricultural use along a topographic high. The site is underlain by sediments of the Upland Unit. Surficial soils are generally Udorthents (disturbed soils).

The APSF site is relatively flat-lying and contains a large engineered excavation about 35 feet below existing grade. Locally, there are small areas that drain less quickly than other areas but the natural drainage at the facility footprint is generally good. Because of the excavation, the cut and fill requirements are considerable. There are no road or rail profiles of any consequence. The APSF site does not lie within the 100-year floodplain nor has there been localized flooding. The groundwater depth at the site is greater than 60 feet deep. The site is hydrogeologically side or downgradient from potential contaminants emanating from $\mathrm{F}$ Area. Elevated levels of tritium have been noted historically in monitoring wells immediately west of the site. There are known soft zone carbonates underlying the site, however, they are well characterized. There are no known faults within one-half mile of the footprint that disrupt the Gordon Aquitard. There are numerous borings and CPT data locations within the site.

\subsubsection{Engineering}

Scoring the sites in the Engineering category focused on critical distances of material transport and construction, and operational suitability. The eleven engineering criteria were given equal weights in the Engineering category. Therefore the raw scores correlate to the ranking of the sites in their suitability to the $\mathrm{Pu}$ missions. Scoring for the engineering criteria are presented in Table 2 and narrative summaries of key elements of the engineering evaluations presented below.

\section{Site 1}

Site 1 scored highest in the Engineering category with the best possible score in four criteria. Site 1 is the closest site to the F Canyon and ETF tie-ins, has the most convenient tie-in to the sanitary plant and has best access for construction equipment. 
Site 1 had no serious engineering drawbacks although the $115 \mathrm{KV}$ power line to F Area must be relocated to make the site useable.

\section{Site 2}

Site 2 had the second highest score in the Engineering category, primarily due to its being scored above average on most criteria and only having one significant weakness, that being a low average elevation likely requiring a lift station for the sanitary line tie-in. Site 2 was closest to an existing NPDES outfall.

\section{Site 3}

Site 3 had the lowest overall engineering score, being the most remote of the sites in terms of existing utilities and improvements. Site 3 scored lowest in four engineering criteria: distance to ETF tie-in, access to existing utilities, proximity to primary road and rail and proximity to NPDES outfall and second lowest for security response time. Site 3 was not seen to have any significant strengths in the engineering category.

\section{Site 4}

Site 4 scored third lowest of the nine sites in the engineering category. Site 4 had moderate scores for four criteria but is distant from the ETF tie-in, has a long response time for protective force, has a large number of monitoring wells requiring relocation and scored lowest for sanitary plant tie-in.

\section{Site 5}

Site 5 received the median score in the engineering category. This site would pose little disruption to existing infrastructure, is convenient to the sanitary tie-in and is relatively close to the primary road and rail line. However it is distant from the ETF tie-in, scores low in construction area suitability and only average in safeguards and security.

\section{Site 6}

Site 6 scored below the average score for all nine sites. Site 6 was distant from the F Canyon tie-in, would substantially disrupt existing infrastructure, had a long security response time and was remote from the other new $\mathrm{Pu}$ facilities and existing utilities. Its strengths were its proximity to the ETF and sanitary tie-ins, proximity to the primary road and rail line and suitability as a construction site.

\section{Site 7}

Site 7 received the second lowest score in the engineering category, scoring lowest or second lowest on five criteria: safeguards and security, distance to F Canyon tie-in, access to utilities, sanitary plant tie-in, construction equipment access and proximity the railroad spur.

\section{Site X}

Site X scored only slightly lower in the engineering category than Site 2. Its strengths were linkage to new Pu facilities, proximity to an NPDES outfall, construction site suitability and safeguards and security. Its most significant weakness was sanitary plant tie-in issues of distance and elevation. 


\begin{abstract}
APSF Site
The APSF site score fourth best of the nine sites. Its primary drawbacks are construction equipment access and construction site suitability due to its small size. The APSF site scored high for its proximity to F Canyon and the other new $\mathrm{Pu}$ facilities, good access to utilities and NPDES outfall and offered least disruption to the existing infrastructure.
\end{abstract}

\title{
5.0 CONCLUSIONS
}

All sites evaluated passed the exclusion criteria (screening test) and are, therefore, suitable for further consideration for the PuDF. Based on the ranked scores, Sites $1, \mathrm{X}$ and 2 are preferable. Due to its small acreage, the APSF site should be considered for expansion of the current footprint of Site 2 or X, or the placement of support components for one or more of the proposed facilities.

Sites 5, 6 and 7 had intermediate scores, while Sites 3 and 4 were clearly the least preferred sites. While the application of screening criteria results in all sites being useable, lower scores are generally indications of increased costs or potential delays in project implementation. Such is the case with Site 5 where current land uses do not preclude redevelopment for PuDF, but cost and schedule issues associated with this site must be considered.

For this report, each individual site was evaluated on its own merit as an integral unit with generic specifications and requirements. As facility designs and requirements become better defined, there are significant opportunities to optimize facility placement relative to the sites that have been evaluated. For example, although Site 1 scored highly in the ranking, its relocation to the west makes it more distant from Sites 2 and X. In addition, its use will be somewhat restricted by a limited ability to connect to other PuDF facilities that would require underground piping or services because of the presence of the Process Sewer line. Additionally, adjacent land parcels that may, or may not, have been evaluated in this study should be examined for optimization purposes. Although the northern end of Site 4 poses significant challenges for use, the southern portion may be more acceptable. Examination of the areas west of Site 5 (between the currently identified boundary and the F-Area fence) might identify land suitable for facility placement resulting in a substantial land parcel equivalent to Site 5, but oriented east-west, rather than north-south. Although evaluation of such options is beyond the scope of this study, they represent significant opportunities for the PuDF program to increase efficiency, reduce costs and minimize environmental impacts. 


\subsection{REFERENCES}

DCS\&W (Duke, Cogema, Stone \& Webster), 2000. Advanced Preliminary Design Package for the Mixed Oxide Fuel Fabrication Facility. Duke, Cogema, Stone \& Webster, Charlotte, NC.

DOE (U.S. Department of Energy). 1999. Surplus Plutonium Disposition Final Environmental Impact Statement, DOE/EIS-0283. Office of Fissile Materials Disposition, U.S. Department of Energy, Washington, DC.

Howard, R. A. and J. E. Matheson. 1968. An introduction to Decision Analysis, in: The Principles and Applications of Decision Analysis, Vol I: General Collection. R. A. Howard, J. E. Matheson, Eds. Stanford Research Institute, Menlo Park, CA.

King, A. and K. Stephenson. 2000. Archaeological Survey and Testing of the Surplus Plutonium Disposition Facilities. Technical Report Series Number 24. Savannah River Archaeology and Anthropology Program. South Carolina Institute of Archaeology and Anthropology, University of South Carolina, Columbia.

Matthews, D. P. 2000 Interoffice Memo to, SSE-2000-00063, Westinghouse Savannah River Company, Aiken, SC.

Wike, L. D. 1995. Facility Siting as a Decision Process at The Savannah River Site (U). WSRC- . RP-98-00170, Westinghouse Savannah River Company, Aiken, SC.

WSRC (Westinghouse Savannah River Company). 1999. F-Area Northeast Expansion Report (U). K-TRT-F-00001, Rev. 0, June 1999. Site Geotechnical Services, Westinghouse Savannah River Company, Aiken, SC. 


\title{
Attachment A
}

WESTINGHOUSE SAVANNAH RIVER COMPANY

INTER-OFFICE MEMORANDUM

SRT-EST-2000-192

May 25, 2000

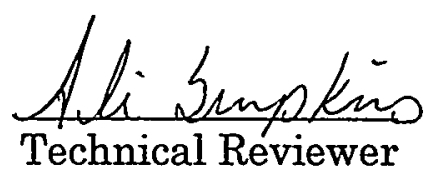

TO: L. WIKE, 773-42A

ENVIRONMENTAL SCIENCE \& TECHNOLOGY

FROM: P. L. LEE, 773-42A (5-3280)<smiles>CCC1(CC)C2CC3CCC2C31</smiles>

ENVIRONMENTAL SCIENCE \& TECHNOLOGY

\begin{abstract}
PRELIMINARY DOSE ESTIMATES FOR PLUTONIUM DISPOSITION FACILITY SITE SELECTION
\end{abstract}

\section{Summary}

Nine locations on the Savannah River Site (SRS) have been identified as potential sites for the placement of the Plutonium Disposition Facility. As part of the site selection criteria, doses to the offsite maximally exposed individual (MEI) have been determined for each location. Doses have also been determined for nearest onsite individual and the individual at the potential sites exposed to a nearby process (291-F Canyon stack). Using the scoring system provided in Attachment 1, each site was assigned a score for the human health portion. Based on the offsite and onsite MEI dose estimates, no one site is superior to any of the others.

\section{Dose Determination}

AXAIRQ (Simpkins 1995a and 1995b) was used to determine fifty-year committed effective dose equivalents (CEDEs). AXAIRQ is used at the 
Savannah River Site to model atmospheric transport and radiological dosimetry for postulated atmospheric releases of short duration. The code strictly adheres to the guidance in USNRC Regulatory Guide 1.145 (USNRC 1982). Meteorological data from 1992-1996 and ICRP 30 dose factors were used (USDOE 1988a and 1988b), full daughter ingrowth was considered and the release was assumed to occur over a two-hour period. For the offsite and nearest onsite MEI doses, the release height was assumed to be ground level. For nearby facility MEI dose, the release height is the 291-F Canyon stack height (61 meters). AXAIRQ does not take into account plume rise due to buoyancy or momentum.

The site coordinates and a brief description of the location of the proposed sites are shown in Table 1. Potential site and onsite MEI locations are shown in Figure 1.

Table 1. Proposed Plutonium Disposition Facility Locations

\begin{tabular}{|c|l|c|c|}
\hline Location & Description & $\begin{array}{c}\text { Easting } \\
\text { Coordinate (ft) }\end{array}$ & $\begin{array}{c}\text { Northing } \\
\text { Coordinate (ft) }\end{array}$ \\
\hline $\mathbf{1}$ & N of $291-\mathrm{F}$ & 53463 & 80056 \\
\hline $\mathbf{2}$ & NNE of $291-\mathrm{F}$ & 55356 & 80269 \\
\hline $\mathbf{3}$ & NE of $291-\mathrm{F}$ & 57423 & 79780 \\
\hline $\mathbf{4}$ & ESE of $291-\mathrm{F}$ & 56589 & 78295 \\
\hline $\mathbf{5}$ & ESE of $291-\mathrm{F}$ & 55800 & 77323 \\
\hline $\mathbf{6}$ & SW of $291-\mathrm{F}$ & 50187 & 76698 \\
\hline $\mathbf{7}$ & SW of $291-\mathrm{F}$ & 51590 & 77293 \\
\hline X & NE of $291-\mathrm{F}$ & 55841 & 78744 \\
\hline APSF & NNE of $291-\mathrm{F}$ & 54885 & 79279 \\
\hline
\end{tabular}

Distances from each potential site location to the site boundary, the nearest onsite individual, and the site the 291-F Canyon Stack are shown in Table 2. The worker and onsite process distances were determined by estimates from a site map. These distances are from the center of the potential site and process to edge of the building closest to that potential site or process. The boundary distances are calculated by AXAIRQ based on the easting and northing coordinates. 
Table 2. Distances to Various Locations for Plutonium Disposition Facility

\begin{tabular}{|c|c|c|c|c|}
\hline $\begin{array}{c}\text { Site } \\
\text { Location }\end{array}$ & $\begin{array}{c}\text { Boundary } \\
\text { Distance (m) }\end{array}$ & $\begin{array}{c}\text { Worker } \\
\text { Location }\end{array}$ & $\begin{array}{c}\text { Worker } \\
\text { Distance (m) }\end{array}$ & $\begin{array}{c}\text { Nearby Process } \\
\text { Distance (m) }\end{array}$ \\
\hline $\mathbf{1}$ & $8790(\mathrm{NNW})$ & $245-1 \mathrm{~F}$ & $160(\mathrm{SSE})$ & $470(\mathrm{~N})$ \\
\hline $\mathbf{2}$ & $8790(\mathrm{NNW})$ & $247-\mathrm{F}$ & $370(\mathrm{SW})$ & $530(\mathrm{NNE})$ \\
\hline $\mathbf{3}$ & $9180(\mathrm{NNW})$ & $247-\mathrm{F}$ & $900(\mathrm{WSW})$ & $950(\mathrm{NE})$ \\
\hline $\mathbf{4}$ & $9510(\mathrm{NNW})$ & $701-16 \mathrm{~F}$ & $470(\mathrm{~W})$ & $680(\mathrm{ESE})$ \\
\hline $\mathbf{5}$ & $9700(\mathrm{NNW})$ & $701-16 \mathrm{~F}$ & $340(\mathrm{NW})$ & $420(\mathrm{ESE})$ \\
\hline $\mathbf{6}$ & $8720(\mathrm{WNW})$ & Construction & $190(\mathrm{NE})$ & $610(\mathrm{SW})$ \\
\hline $\mathbf{7}$ & $9620(\mathrm{NNW})$ & $701-17 \mathrm{~F}$ & $610(\mathrm{ENE})$ & $870(\mathrm{SW})$ \\
\hline $\mathbf{X}$ & $9270(\mathrm{NNW})$ & $247-\mathrm{F}$ & $270(\mathrm{SW})$ & $430(\mathrm{NE})$ \\
\hline APSF & $9070(\mathrm{NNW})$ & $235-11 \mathrm{~F}$ & $140(\mathrm{~W})$ & $420(\mathrm{NNE})$ \\
\hline
\end{tabular}

Source terms for worst case accidents from the Plutonium Disposition Facility have been estimated in an Environmental Impact Statement (EIS). Analysis indicates that four grams of plutonium could potentially be released to the environment from the Mixed Oxide Fuel (MOX) facility (USDOE 1999). For comparison, four grams of plutonium in the form of MOX powder is assumed to be released through the building ventilation due to a design based earthquake. The isotopic composition of the released plutonium is listed in Table. 3.

Table 3. Isotopic Composition of Plutonium (USDOE 1999).

\begin{tabular}{|c|c|c|}
\hline Isotope & Composition (\%) & Activity (Ci) \\
\hline Plutonium-238 & 0.03 & $2.06 \mathrm{E}-02$ \\
\hline Plutonium -239 & 92.2 & $2.29 \mathrm{E}-01$ \\
\hline Plutonium -240 & 6.46 & $5.89 \mathrm{E}-02$ \\
\hline Plutonium -241 & 0.05 & $2.06 \mathrm{E}-01$ \\
\hline Plutonium -242 & 0.1 & $1.57 \mathrm{E}-05$ \\
\hline Americium -241 & 1.0 & $1.24 \mathrm{E}-01$ \\
\hline
\end{tabular}

Source terms for the 291-F Canyon Stack are based on the types of radionuclides released annually from the 291-F stack as listed in the Savannah River Site annual environmental report (WSRC 2000). For comparison, a one curie release of each radionuclide listed in Table 4 was assumed. 
Table 4. Radionuclides Released from the 291-F Canyon Stack

\begin{tabular}{|c|c|}
\hline \multicolumn{2}{|c|}{ Isotopes Released Annually from 291-F } \\
\hline Tritium & Uranium-234 \\
Carbon-14 & Uranium-235 \\
Krypton-85 & Ừ்anium-238 \\
Strontium-90 & Plutonium-238 \\
Iodine-129 & Plutonium-239 \\
Xenon-135 & Americium-241 \\
Cesium-137 & Curium-244 \\
\hline
\end{tabular}

AXAIRQ was executed with the appropriate worker and process distances for each of the nine potential release locations and the 291-F Canyon Stack. The resulting CEDEs are shown in Table 5 for meteorological conditions for which doses are not exceeded $99.5 \%$ of the time in the particular sector. Doses for the nearest onsite individual to each potential site and the site worker due to exposure to the nearby processes were scaled using relative air concentrations from the worst sector doses produced by AXAIRQ for the assigned distance.

Table 5. CEDE for Potential Atmospheric Releases Resulting from

Plutonium Disposition Facility for 99.5\% Meteorological Conditions

\begin{tabular}{|c|c|c|c|}
\hline $\begin{array}{c}\text { Site } \\
\text { Location }\end{array}$ & $\begin{array}{c}\text { MEI Offsite } \\
\text { Dose (rem) }\end{array}$ & $\begin{array}{c}\text { Nearest Onsite } \\
\text { Worker Dose (rem) }\end{array}$ & $\begin{array}{c}\text { Site Worker Dose } \\
\text { from Nearby Onsite } \\
\text { Process (rem) }\end{array}$ \\
\hline $\mathbf{1}$ & 0.82 & 94 & 13 \\
\hline $\mathbf{2}$ & 0.82 & 37 & 12 \\
\hline $\mathbf{3}$ & 0.78 & 9 & 9 \\
\hline $\mathbf{4}$ & 0.75 & 24 & 10 \\
\hline $\mathbf{5}$ & 0.73 & 43 & 12 \\
\hline $\mathbf{6}$ & 0.76 & 115 & 11 \\
\hline $\mathbf{7}$ & 0.74 & 19 & 10 \\
\hline $\mathbf{X}$ & 0.77 & 62 & 13 \\
\hline APSF & 0.79 & 178 & 13 \\
\hline
\end{tabular}

\section{Scoring of Human Health Effects}

Using the scoring system shown in the attachment, scores have been assigned to the various human health effects categories and are shown in 
L. Wike

Table 6. The score for offsite risk was selected to be a perfect score of twenty for each of the locations since all proposed release locations are centrally located with respect to the site boundary and in close proximity to each other. The effect on SRS workers was determined by looking comparatively at the doses that were reported in Table 5 . The effect on the nearby workers vary with the distance of the worker to the potential sites. The effect to workers at the potential sites from an existing facility was also assigned a perfect score of twenty for each location due to their distance from the nearby process and prevailing wind direction for SRS. As seen in the attachment, these scores must be added to the emergency preparedness scores to determine the overall Human Health score. However, the scores due to offsite risk, nearby workers and effects from nearby facilities indicate no one site is superior to the other for potential placement of the Plutonium Disposition Facility.

Table 6. Human Health Effects Scoring

\begin{tabular}{|c|c|c|c|c|}
\hline \multicolumn{5}{|c|}{ Score (Each out of 20) } \\
\hline Site & $\begin{array}{c}\text { Offsite } \\
\text { Risk }\end{array}$ & $\begin{array}{c}\text { Effect on Nearby } \\
\text { Workers }\end{array}$ & $\begin{array}{c}\text { Effect from } \\
\text { Nearby } \\
\text { Facilities }\end{array}$ & $\begin{array}{c}\text { Total } \\
\text { Score } \\
\text { (60 possible) }\end{array}$ \\
\hline $\mathbf{1}$ & 20 & 17 & 20 & 57 \\
\hline $\mathbf{2}$ & 20 & 20 & 20 & 60 \\
\hline $\mathbf{3}$ & 20 & 20 & 20 & 60 \\
\hline $\mathbf{4}$ & 20 & 20 & 20 & 60 \\
\hline $\mathbf{5}$ & 20 & 20 & 20 & 60 \\
\hline $\mathbf{6}$ & 20 & 16 & 20 & 56 \\
\hline $\mathbf{7}$ & 20 & 20 & 20 & 60 \\
\hline X & 20 & 19 & 20 & 59 \\
\hline APSF & 20 & 15 & 20 & 55 \\
\hline
\end{tabular}


L. Wike

\section{References}

Simpkins 1995a Simpkins, A.A., "Verification of AXAIRQ," WSRC-RP-95708 Westinghouse Savannah River Technology Center, Aiken, SC, 1995

Simpkins 1995b Simpkins, A.A., "AXAIRQ User's Manual," WSRC-RP-95709 Westinghouse Savannah River Technology Center, Aiken, SC, 1995

USDOE 1988a US Department of Energy, "External Dose-Rate Conversion Factors for Calculation of Dose to the Public," DOE/EH-0070, Washington, DC, July 1988.

USDOE 1988b US Department of Energy, "Internal Dose-Rate Conversion Factors for Calculation of Dose to the Public," DOE/EH-0071, Washington, DC, July 1988.

USDOE 1999 US Department of Energy, "Surplus Plutonium Disposition Facility Final Environmental Impact Statement: Volume II," DOE/EIS-0283, Washington, DC, November 1999.

USNRC 1982 US Nuclear Regulatory Commission, "Regulatory Guide 1.145: Atmospheric Dispersion Models for Potential Accidental Consequence Assessments at Nuclear Power Plants," Rev. 1, Washington, DC, November 1982.

WSRC 1999 Westinghouse Savannah River Company "Environmental Data for 1999" WSRC-TR-99-00301, Aiken, SC, 2000.

cc: $\quad$ J.B. Gladden ,773-42A

A.A. Simpkins, $773-42 A$

G.T. Jannik, 773-42A

ES\&T File, $773-42 \mathrm{~A}$ 
L. Wike

Attachment 1. Criteria for Scoring for Each of the Four Potential Sites for the Plutonium Disposition Facility Criteria Scoring Sheet with Weights

\begin{tabular}{|c|c|c|c|c|c|c|c|c|c|c|c|c|}
\hline Category & Weight & Criteria & Weight & Site 1 & Site 2 & Site 3 & Site 4 & Site 5 & Site 6 & Site 7 & Site X & APSF \\
\hline \multirow[t]{4}{*}{ Ecology } & 10 & . &. & & & & & & & & & \\
\hline & & Terrestrial & 20 & & & & & & & & & \\
\hline & & Wetlands & 30 & & & & & & & & & \\
\hline & & Aquatic & 50 & & & & & & & & & \\
\hline \multirow[t]{5}{*}{ Human Health } & 25 & & & & & & & & & & & \\
\hline & & Risk to Offsite Population & 20 & & & & & & & & & \\
\hline & & $\begin{array}{l}\text { Effect on Plutonium Disposition Facility } \\
\text { Workers from Nearby Facilities }\end{array}$ & 20 & & & & & & & & & \\
\hline & & $\begin{array}{l}\text { Effect of Plutonium Disposition Facility on } \\
\text { Workers in Nearby Facilities }\end{array}$ & 20 & & & & & & & & & \\
\hline & & Emergency Response/Preparedness & 40 & & & & & & & & & \\
\hline \multirow[t]{6}{*}{ Geoscience } & 30 & & & & & & & & & & & \\
\hline & & Topography & 15 & & & & & & & & & \\
\hline & & Surface Hydrology & 10 & & & & & & & & & \\
\hline & & Subsurface Hydrology & 30 & & & & & & & & & \\
\hline & & Geology & 30 & & & & & & • & & & \\
\hline & & Seismology & 15 & & & & & & & & & \\
\hline \multirow[t]{7}{*}{ Engineering } & 35 & & & & & & & & & & & \\
\hline & & Distance to F-Canyon Tie in & 12 & & & & & & & & & \\
\hline & & Distance ETF tie in & 8 & & & & & & & & & \\
\hline & & Disruption to Existing Infrastructure/Utilities & 7 & & & & & & & & & \\
\hline & & $\begin{array}{l}\text { Access to Utilities (operation and } \\
\text { construction) }\end{array}$ & 12 & & & & & & & & & \\
\hline & & Linkage to other New Pu Facilities & 6 & & & & & & & & & \\
\hline & & Sanitary Plant tie-in & 8 & & & & & & & & & \\
\hline
\end{tabular}


L. Wike

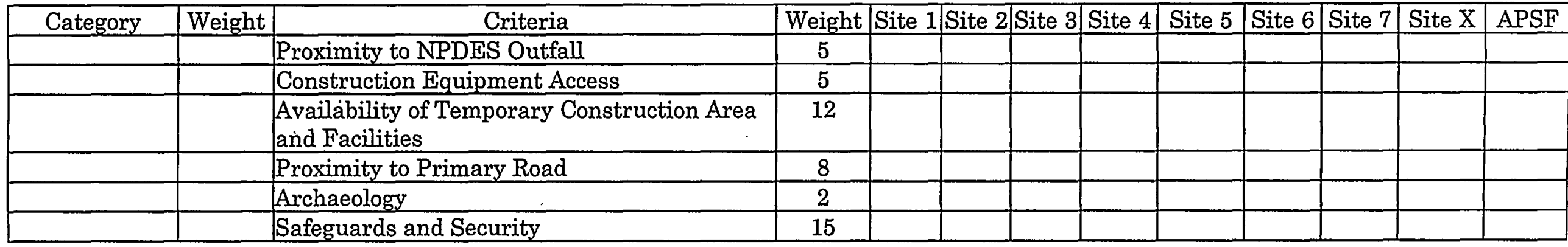


Page 9

$5 / 25 / 2000$

L. Wike

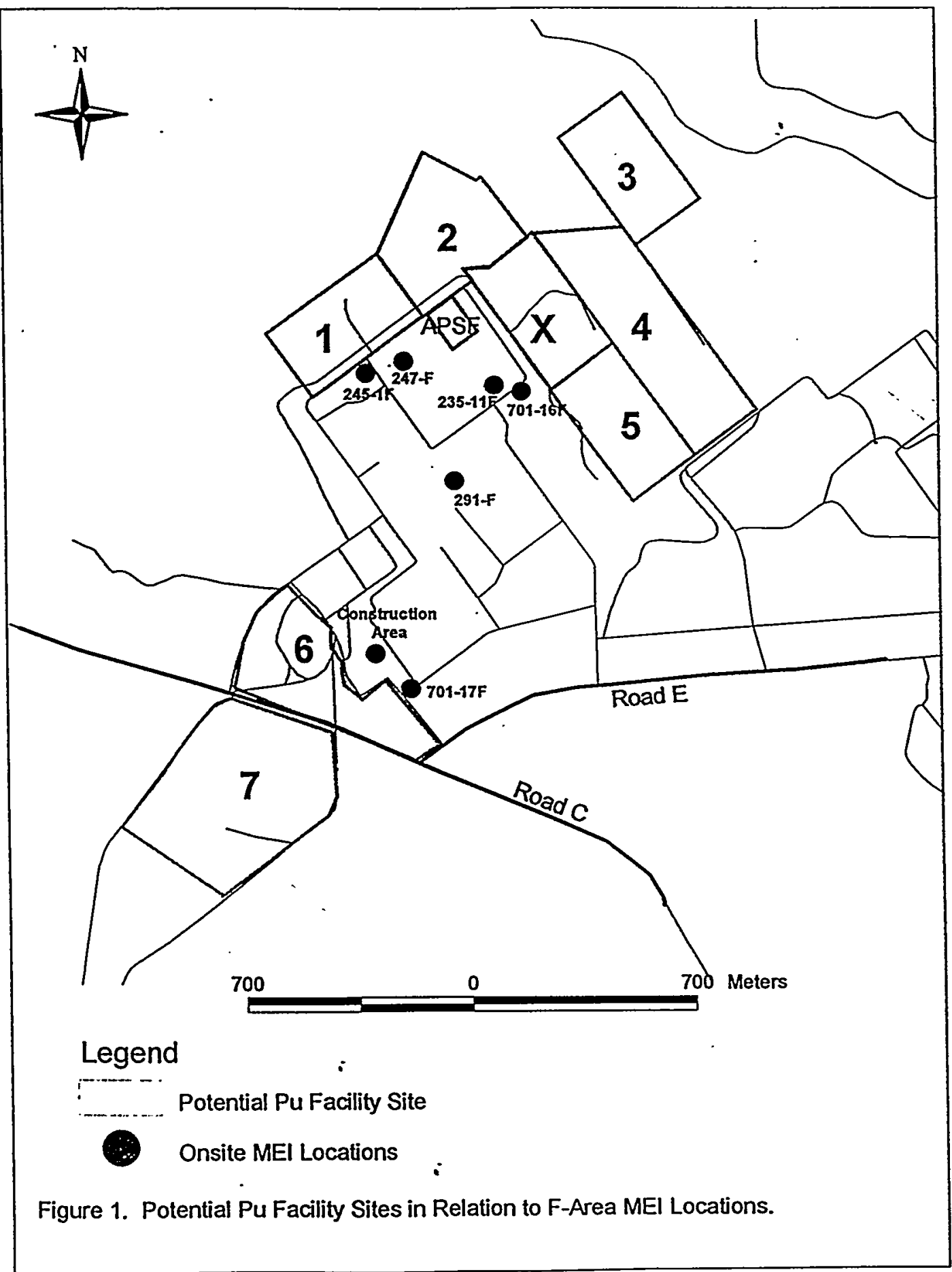




\section{Attachment B}

SRT-SCS-2000-00047

Wéstinghouse Savannah River Company

Savannah River Technology Center

Aiken, SC 29808 is:

\section{Sensitivity Analyses of Site Selection for Surplus Plutonium}

Disposition Facilities at the Savannah River Site (U)

S:P. Harris

June 28, 2000

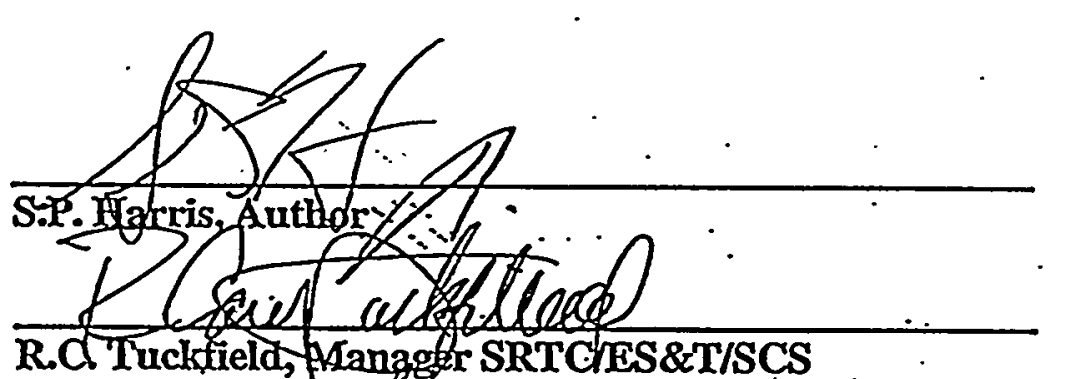

R.CT Tucktield, Wangger SRTGES\&T/SCS

Key Words: High L̇èrel Waste, Sensitivity Analysis, Site Selection, Plutonium

Disposition, Weighted Criteria

Retention Period: ·Permanent

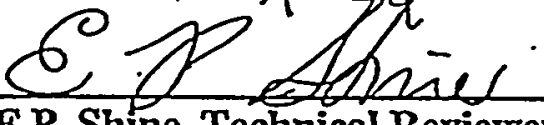

E.P. Shine, Technical Reviewer

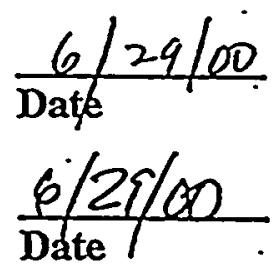

$6 / 29 / 0 y$ 


\section{Abstract}

\section{S. P. Harris, SRTC/SCS}

Sensitivity Analyses of Site Selection for Surplus Plutonium Disposition Facilities at the Savannah River Site (U), WSRC-TR-2000-00220.

Sensitivity analysis has demonstrated that Sites 1,2, APSF and X and are best suited over widely varying error ranges in primary weights. The primary weights representing the relative importance of ecology, human health, geoscience and engineering present the greatest potential for variability. Secondary weights representing the criteria within the categories were considered to be of lesser variability since category experts determined them. They were not varied. The primary weights were simultaneously varied from $10 \%$ to $40 \%$ using the method of extreme vertices. Statistical analysis of the resulting weighted scores confirmed the robustness of the site selection. 


\title{
Sensitivity Analyses of Site Selection for Surplus Plutonium Disposition Facilities at the Savannah River Site (U)
}

\author{
S. P. Harris
}

\section{Summary}

A site selection study was conducted to evaluate locations for the proposed Surplus Plutonium Disposition Facilities ${ }^{(1)}$. Presented in this report is a sensitivity analysis that demonstrates the robustness of the site evaluations.

Sensitivity analysis has demonstrated that Sites 1, 2, APSF and X and are best suited over widely varying error ranges in primary weights. Primary weights representing the relative importance of ecology, human health, geoscience and engineering were simultaneously varied over a wide range in order to demonstrate the robustness of the selection process. The primary weights represent the greatest potential for variability. The statistical results were conditional on the scores within each category given by an expert panel. Secondary weights representing the criteria within the categories considered to be of lesser influence were not varied. Individual site criteria scores were held constant in the sensitivity analysis.

\section{Background}

An expert panel identified, assessed and ranked potential sites for the proposed Plutonium Disposition Facilities (PuDF) complex at the Savannah River Site (SRS). The panel employed a decision making process based on the Nominal Group, Delphi and Decision analysis process ${ }^{(2)}$. The members included subject matter experts knowledgeable in the areas of facility engineering, regulatory compliance (NEPA) and environmental sciences.

The panel established categories, rating criteria, and weighting factors for ranking potential sites. Nine locations in the vicinity of F-Area were considered for the proposed facilities. The evaluation categories included ecological, human health, geoscience and engineering considerations. The subject matter experts then established the rating criteria within each category. Finally the weights and utility function values (UF) were established within each category (Table 1) for nine potential sites. The utility function values are the sum of weighted scores within each of the nine evaluation categories. Presented in this report is a statistical sensitivity analysis that demonstrates the robustness of their evaluation.

\section{Statistical Approach}

A strategy for sensitivity analysis for alternative methods for site selection is presented. The primary weights were varied between categories because it was felt that they represent the greatest potential for variability. The utility function values within each category were not varied because they are considered to have low variability since they reside within each category 
of expertise. The sensitivity analysis was conducted using $\mathrm{SAS}^{(3)}$ as the primary tool. The data were analyzed using Statgraphics ${ }^{(4)}$.

The primary category weights, as recorded from the Site Assessment Matrix (Table 1) are shown in Chart 1. In addition, the minimum and maximum values corresponding to a $10 \%$ to $40 \%$ decrease or increase are also shown.

Typically, in a sensitivity study, we would review the impact on the site ranking using all $2^{4}$ combinations of minimums and maximums for each category. However, we are further constrained by the fact that the sum of the primary weights must equal unity. Therefore, the proper selection of weight combinations will lie on the hyperplane defined by $\sum_{i} W_{i}=1$. The final weighted score for each site is calculated as $W S C O R E=\sum_{i} W_{i} \sum_{j} U F_{j}$ where i is the category and $\mathrm{j}$ is the criteria within each category.

The extreme vertices of this region were selected, i.e.: points on the edges of the hyperplane defined by the constraints in addition to the centroid. This was implemented using the SAS ADXINIT and ADXXVERT macros ${ }^{(5)}$ and resulted in 39 different combinations of primary weights for use in each potential site's sensitivity analysis (Table 2). The final weighted score is also shown.

\section{Chart 1}

\section{Sensitivity Ranges for Percent Change in Primary Weight}

\begin{tabular}{|c|c|c|c|c|c|c|c|c|c|}
\hline Category & Primary & \multicolumn{2}{|c|}{$10 \%$} & \multicolumn{2}{|c|}{$20 \%$} & \multicolumn{2}{|c|}{$30 \%$} & \multicolumn{2}{|c|}{$40 \%$} \\
\hline & Weight & Min & Max & $\underline{\text { Min }}$ & Max & Min & Max & Min & Max \\
\hline Ecology & 10 & 9 & 11 & 8 & 12 & 7 & 13 & 6 & 14 \\
\hline Human Health & 25 & 22.5 & 27.5 & 20 & 30 & 17.5 & 32.5 & 15 & 35 \\
\hline Geoscience & 30 & 27 & 33 & 24 & 36 & 21 & 39 & 18 & 42 \\
\hline Engineering & 35 & 31.5 & 38.5 & 28 & 42 & 24.5 & 45.5 & 21 & 49 \\
\hline
\end{tabular}

The weights in Table 2 were evaluated using Statgraphics ${ }^{(4)}$. The resulting graphics are included in Plot 1 and statistical summary statistics are shown in Table 3. 


\section{Analyses of Weighted Scores}

The Box-and Whisker Plots (Plot 1) show the range and variation in total weighted score for each of the alternative sites. The average total weighted score, the median and standard deviation are shown for each alternative in Table 3.

Each Box-and-Whisker plot displays the minimum and maximum values, the 25 th, $50^{\text {th }}$ (median) and 75 th percentiles. The box is aligned vertically and encloses the interquartile range (the 25th to 75th percentile). The upper part of the box represents the 75th percentile while the lower part represents the 25th percentile. Extreme points will also be shown extending from the box.

The Box-and-Whisker Plots of site scores show that Sites 1,2, APSF and X are the best suited for the proposed missions based on their total weighted scores over widely varying primary weights from up to $10 \%$ to $40 \%$. Sites 3 and 4 are the least favorably disposed for the missions. Sites 5 and 6 possessed intermediate scores. These conclusions are reinforced by the analysis of ranks (Table 4).

\section{Statistical Software}

Two software packages are employed in deriving the sensitivity analysis results namely SAS Release 6.12 and Statgraphics Version 4.0. SAS is a commercial $4^{\text {th }}$ generation computer programming language and Statgraphics is a desktop statistical package. Both programs are commercially available off the shelf software. Both programs are statistical tools that have been previously employed to perform statistical analyses at SRS. In this application, the programs perform standard statistical and arithmetic base functions and algorithmic functions.

A verification of the correctness of algorithm functions was performed ${ }^{(6)(7)}$. A validation of the software performance was accomplished by analyzing a representative sample of input data and comparing output data to a hand calculated output of the sensitivity analyses. This calculation by alternative method also verified the SAS and Statgraphics base functions. The justification for the sample selection was verified and difference between the results was then verified to lie within an acceptable error band suitable for this application. 


\section{References}

${ }^{(1)}$ Gladden, J.B., et. al. (2000), Site Selection for the Surplus Plutonium Disposition Facilities at the Savannah River Site, WSRC-RP-2000-00391.

${ }^{(2)}$ Wike, L.D.(1995), Facility Siting as a Decision Process at Thè Savannah River Site(U), WSRC-RP-95-664, Rev. 0.

${ }^{(3)}$ SAS, Release 6.12, SAS Institute, Cary, N.C.

${ }^{(4)}$ Statgraphics, Version 4, Manugistics Inc., Rockville, M.D.

${ }^{(5)}$ SAS/QC ${ }^{\circledR}$ Software: Reference. 1989. Version 6, First Addition. Cary, NC: SAS Institute Inc., 660pp.

${ }^{(6)}$ Harris, S. P.(1998), Software Verification and Validation for Sensitivity Analysis of Alternative Methods for Dispositioning of High Level Salt Waste(U), SRT-SCS-98-027.

(7) Harris, S.P.(1999), Supplemental QA Requirements for DOE/RW-0333P(U), SRT-SCS-99007. 


\section{Table 1}

\section{Evaluation Categories, Criteria, Weights and Utility Function Values for Site Selection}

\begin{tabular}{|c|c|c|c|c|c|c|c|c|c|c|c|c|}
\hline Category & Wt & Criteria & Weight & Site 1 & Site 2 & Site 3| & Site 4| & Site 5 & Site 6 & Site 7 & Site X & APSF \\
\hline \multirow[t]{6}{*}{ Ecology } & 10 & & & & & & & & & & & \\
\hline & & \begin{tabular}{|l|} 
Terrestrial \\
\end{tabular} & 20 & 20 & 20 & 15 & 15 & 20 & 20 & 20 & 20 & 20 \\
\hline & & \begin{tabular}{|l|} 
Wetlands \\
\end{tabular} & 30 & 30 & $\because 30$ & 20 & 20 & 30 & 30 & 30 & 30 & 30 \\
\hline & & Aquatic & 50 & 50 & 30 & 25 & 25 & 50 & 50 & 30 & 50 & 50 \\
\hline & & Total & & 100 & 80 & 60 & 60 & 100 & 100 & 80 & 100 & 100 \\
\hline & & Weighted Total & & 10 & 8 & 6 & 6 & 10 & 10 & 8 & 10 & 10 \\
\hline \multirow[t]{7}{*}{ Human Health } & 25 & & & & & & & & & & & \\
\hline & & Risk to Offsite Population & 20 & 20 & 20 & 20 & 20 & 20 & 20 & 20 & 20 & 20 \\
\hline & & $\begin{array}{l}\text { Effect on Workers in Nearby } \\
\text { Facilities }\end{array}$ & 20 & 17 & 20 & 20 & 20 & 20 & 16 & 20 & 19 & $\overline{15}$ \\
\hline & & $\begin{array}{l}\text { Effect on Workers from Nearby } \\
\text { Facilities }\end{array}$ & 20 & 20 & 20 & 20 & 20 & 20 & 20 & 20 & 20 & 20 \\
\hline & & Emergency Response/Preparedness & 40 & 35 & 35 & 30 & 35 & 35 & 25 & 25 & 35 & 35 \\
\hline & & Total & & 92 & 95 & 90 & 95 & 95 & 81 & 85 & 94 & 90 \\
\hline & & Weighted Total & & 23 & 24 & 23 & 24 & 24 & 20 & 21 & 24 & 22.5 \\
\hline \multirow[t]{8}{*}{ Geoscience } & 30 & & & & & & & & & & & \\
\hline & & Topography & 15 & 10 & 9 & 11 & 6 & 7 & 11 & 9 & 10 & 13 \\
\hline & & Surface Hydrology & 15 & 14 & 13 & 14 & 13 & 13 & 15 & 13 & 14 & 15 \\
\hline & & Subsurface Hydrology & 30 & 18 & 25 & 20 & 5 & 15 & 15 & 23 & 23 & 21 \\
\hline & & Geology & 30 & 8 & 11 & 11 & 8 & 10 & 13 & 13 & 13 & 16 \\
\hline & & Seismology & 10 & 6 & 6 & 6 & 6 & 6 & 6 & 6 & 6 & 6 \\
\hline & & Total & & 56 & 64 & 62 & 38 & 51 & 60 & 64 & 66 & 71 \\
\hline & & Weighted Total & & 17] & 19 & 19 & 11 & 15 & 18 & 19 & 20 & 21.3 \\
\hline \multirow[t]{16}{*}{ Engineering } & 35 & & & & & & & & & & & \\
\hline & & Distance to F Canyon tie in & 12 & 10.8 & 8.4 & 3.6 & 4.8 & 6.6 & 2.4 & 1.2 & 6.6 & 9.6 \\
\hline & & Distance to ETF tie in & 8 & 7.2 & 5.6 & 0.8 & 1.6 & 2.4 & 6.4 & 4.8 & 3.2 & 4 \\
\hline & & $\begin{array}{l}\text { Disruption to Existing } \\
\text { Infrastr/Utilities }\end{array}$ & 7 & 3.5 & 4.2 & 4.9 & 1.4 & 5.6 & 2.1 & 4.2 & 2.8 & 6.3 \\
\hline & & Access to Utilities (oper and const) & 12 & 10.8 & 7.8 & 1.2 & 4.8 & 6 & 3.6 & 1.2 & 7.8 & 9.6 \\
\hline & & Linkage to Other New Pu Facilities & 6 & 3 & 4.2 & 1.8 & 3.6 & 2.4 & 1.2 & 1.2 & 5.4 & 4.8 \\
\hline & & Sanitary Plant Tie-In & 8 & 7.2 & 1.6 & 3.2 & 0.8 & 5.6 & 6.4 & 4 & 4.8 & 2.4 \\
\hline & & Proximity to NPDES Outfall & 5 & 2 & 4.5 & 0.5 & 3 & 2.5 & 1.5 & 2.5 & 3.5 & 4 \\
\hline & & Construction Equipment Access & 5 & 3.5 & 3 & 0.5 & 1 & 2.25 & 4 & 3.5 & 2.25 & 1.5 \\
\hline & & Suitability for Construction & 12 & 6.6 & 8.4 & 3.6 & 6.6 & 4.8 & 10.8 & 10.8 & 9.6 & 1.2 \\
\hline & & Proximity to Primary Road and Rail & 8 & 4 & 2.8 & 0.8 & 4.8 & 5.6 & 6.8 & 1.6 & 2.8 & 2.8 \\
\hline & & Archaeology & 2 & 2 & 0 & 0 & 2 & 2 & 1 & 1 & 0 & 2 \\
\hline & & Safeguards and Security & 15 & 10.5 & 9 & 3.75 & 6 & 7.5 & 3.75 & 3 & 10.5 & 10.5 \\
\hline & & Total & & 71.1 & 59.5 & 24.7 & 40.4 & 53.3 & 50 & 39 & 59.3 & 58.7 \\
\hline & & Weighted Total & & 25 & 21 & 8.6 & 14 & 19 & 18 & 14 & 21 & 20.5 \\
\hline & & & & & & & & & & & & \\
\hline Wt Score & & & & 74.7 & 71.8 & 55.7 & 55.3 & 67.7 & \begin{tabular}{|l|}
65.7 \\
\end{tabular} & 62.1 & 74 & 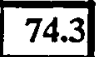 \\
\hline Rank & & & & 1 & 4 & 8 & 9 & 5 & 6 & 7 & 3 & 2 \\
\hline
\end{tabular}




\section{Table 2}

\section{Extreme Vertices for Evaluation of Primary Weights Assuming up to a $10 \%$ Change}

\section{WSCORE $=$ Final Weighted Score}

\begin{tabular}{|c|c|c|c|c|c|c|c|c|c|c|}
\hline Row & Site & P1 & P2 & P3 & P4 & U1 & $\mathrm{U} 2$ & U3 & U4 & WSCORE \\
\hline 1 & 1 & 0.11 & \begin{tabular}{|l}
0.275 \\
\end{tabular} & 0.270 & 0.345 & 100 & 92 & 56 & 71.1 & 75.950 \\
\hline 2 & 1 & 0.11 & \begin{tabular}{|l|}
0.275 \\
\end{tabular} & 0.300 & 0.315 & 100 & 92 & 56 & 71.1 & 75.497 \\
\hline 3 & 1 & 0.11 & 0.225 & 0.330 & 0.335 & 100 & 92 & 56 & 71.1 & 73.999 \\
\hline 4 & 1 & 0.11 & 0.225 & 0.280 & 0.385 & 100 & 92 & 56 & 71.1 & 74.754 \\
\hline 5 & 1 & 0.11 & 0.245 & 0.330 & 0.315 & 100 & 92 & 56 & 71.1 & 74.417 \\
\hline 6 & 1 & 0.11 & 0.235 & 0.270 & 0.385 & 100 & 92 & 56 & 71.1 & 75.114 \\
\hline 7 & 1 & 0.09 & 0.275 & 0.270 & 0.365 & 100 & 92 & 56 & 71.1 & 75.372 \\
\hline 8 & 1 & 0.09 & 0.275 & 0.320 & 0.315 & 100 & 92 & 56 & 71.1 & 74.617 \\
\hline 9 & 1 & 0.09 & 0.225 & 0.330 & 0.355 & 100 & 92 & 56 & 71.1 & 73.421 \\
\hline 10 & 1 & 0.09 & 0.225 & 0.300 & 0.385 & 100 & 92 & 56 & 71.1 & 73.874 \\
\hline 11 & 1 & 0.09 & 0.265 & 0.330 & 0.315 & 100 & 92 & 56 & 71.1 & 74.257 \\
\hline 12 & 1 & 0.09 & 0.255 & \begin{tabular}{|l|}
0.270 \\
\end{tabular} & 0.385 & 100 & 92 & 56 & 71.1 & 74.954 \\
\hline 13 & 1 & 0.09 & 0.225 & 0.315 & 0.370 & 100 & 92 & 56 & 71.1 & 73.647 \\
\hline 14 & 1 & 0.09 & 0.275 & 0.295 & 0.340 & 100 & 92 & 56 & 71.1 & 74.994 \\
\hline 15 & 1 & 0.11 & 0.225 & \begin{tabular}{|l|}
0.305 \\
\end{tabular} & 0.360 & 100 & 92 & 56 & 71.1 & 74.376 \\
\hline 16 & 1 & 0.11 & 0.275 & 0.285 & 0.330 & 100 & 92 & 56 & 71.1 & 75.723 \\
\hline 17 & 1 & 0.09 & 0.265 & 0.270 & \begin{tabular}{|l|}
0.375 \\
\end{tabular} & 100 & 92 & 56 & 71.1 & 75.163 \\
\hline 18 & 1 & 0.09 & 0.245 & 0.330 & 0.335 & 100 & 92 & 56 & 71.1 & 73.839 \\
\hline 19 & 1 & 0.11 & 0.255 & 0.270 & 0.365 & 100 & 92 & 56 & 71:1 & 75.532 \\
\hline 20 & 1 & 0.11 & 0.235 & 0.330 & \begin{tabular}{|l|}
0.325 \\
\end{tabular} & 100 & 92 & 56 & 71.1 & 74.208 \\
\hline 21 & 1 & 0.09 & 0.270 & 0.325 & 0.315 & 100 & 92 & 56 & 71.1 & 74.437 \\
\hline 22 & 1 & 0.09 & 0.240 & 0.285 & 0.385 & 100 & 92 & 56 & 71.1 & 74.414 \\
\hline 23 & 1 & 0.11 & 0.260 & 0.315 & 0.315 & 100 & 92 & 56 & 71.1 & 74.957 \\
\hline 24 & 1 & 0.11 & 0.230 & 0.275 & \begin{tabular}{|l|}
0.385 \\
\end{tabular} & 100 & 92 & 56 & 71.1 & 74.934 \\
\hline 25 & 1 & 0.10 & 0.225 & 0.330 & 0.345 & 100 & 92 & 56 & 71.1 & 73.710 \\
\hline 26 & 1 & 0.10 & 0.275 & 0.270 & 0.355 & 100 & 92 & 56 & 71.1 & 75.661 \\
\hline 27 & 1 & 0.10 & 0.225 & 0.290 & \begin{tabular}{|l|}
0.385 \\
\end{tabular} & 100 & 92 & 56 & 71.1 & 74.314 \\
\hline 28 & 1 & 0.10 & 0.275 & 0.310 & \begin{tabular}{|l|}
0.315 \\
\end{tabular} & 100 & 92 & 56 & 71.1 & 75.057 \\
\hline 29 & 1 & 0.10 & 0.245 & 0.270 & \begin{tabular}{|l|}
0.385 \\
\end{tabular} & 100 & 92 & 56 & 71.1 & 75.034 \\
\hline 30 & 1 & 0.10 & 0.255 & 0.330 & \begin{tabular}{|l|}
0.315 \\
\end{tabular} & 100 & 92 & 56 & 71.1 & 74.337 \\
\hline 31 & 1 & 0.09 & 0.253 & 0.303 & 0.353 & 100 & 92 & 56 & 71.1 & 74.415 \\
\hline 32 & 1 & 0.11 & 0.247 & 0.297 & 0.347 & 100 & 92 & 56 & 71.1 & 74.955 \\
\hline 33 & 1 & 0.10 & 0.225 & 0.310 & 0.365 & 100 & 92 & 56 & 71.1 & 74.012 \\
\hline 34 & 1 & 0.10 & 0.275 & 0.290 & 0.335 & 100 & 92 & 56 & 71.1 & 75.359 \\
\hline 35 & 1 & 0.10 & 0.260 & 0.270 & 0.370 & 100 & 92 & 56 & 71.1 & 75.347 \\
\hline 36 & 1 & 0.10 & 0.240 & \begin{tabular}{|l|}
0.330 \\
\end{tabular} & 0.330 & 100 & 92 & 56 & 71.1 & 74.023 \\
\hline 37 & 1 & 0.10 & 0.265 & 0.320 & 0.315 & 100 & 92 & 56 & 71.1 & 74.697 \\
\hline 38 & 1 & 0.10 & 0.235 & 0.280 & \begin{tabular}{|l|}
0.385 \\
\end{tabular} & 100 & 92 & 56 & 71.1 & 74.674 \\
\hline 39 & 1 & 0.10 & 0.250 & 0.300 & \begin{tabular}{|l|}
0.350 \\
\end{tabular} & 100 & 92 & 56 & 71.1 & 74.685 \\
\hline 40 & 2 & 0.11 & 0.275 & 0.270 & \begin{tabular}{|l|}
0.345 \\
\end{tabular} & 80 & 95 & 64 & 59.5 & 72.733 \\
\hline 41 & 2 & 0.11 & 0.275 & 0.300 & \begin{tabular}{|l|}
0.315 \\
\end{tabular} & 80 & 95 & 64 & 59.5 & 72.868 \\
\hline
\end{tabular}




\begin{tabular}{|c|c|c|c|c|c|c|c|c|c|c|}
\hline 42 & 2 & 0.11 & 0.225 & 0.330 & 0.335 & 80 & 95 & 64 & 59.5 & 71.228 \\
\hline 43 & 2 & 0.11 & 0.225 & 0.280 & 0.385 & 80 & 95 & 64 & 59.5 & 71.003 \\
\hline 44 & 2 & 0.11 & 0.245 & 0.330 & 0.315 & 80 & 95 & 64 & 59.5 & 71.938 \\
\hline 45 & 2 & 0.11 & 0.235 & 0.270 & 0.385 & 80 & 95 & 64 & 59.5 & 71.313 \\
\hline 46 & 2 & 0.09 & 0.275 & 0.270 & 0.365 & 80 & 95 & 64 & 59.5 & 72.323 \\
\hline 47 & 2 & 0.09 & 0.275 & 0.320 & 0.315 & 80 & 95 & 64 & 59.5 & 72.548 \\
\hline 48 & 2 & 0.09 & 0.225 & 0.330 & 0.355 & 80 & 95 & 64 & 59.5 & 70.818 \\
\hline 49 & 2 & 0.09 & 0.225 & 0.300 & 0.385 & 80 & 95 & 64 & 59.5 & 70.683 \\
\hline 50 & 2 & 0.09 & 0.265 & 0.330 & 0.315 & 80 & 95 & 64 & 59.5 & 72.238 \\
\hline 51 & 2 & 0.09 & 0.255 & 0.270 & 0.385 & 80 & 95 & 64 & 59.5 & 71.613 \\
\hline 52 & 2 & 0.09 & 0.225 & 0.315 & 0.370 & 80 & 95 & 64 & 59.5 & 70.750 \\
\hline 53 & 2 & 0.09 & 0.275 & 0.295 & 0.340 & 80 & 95 & 64 & 59.5 & 72.435 \\
\hline 54 & 2 & 0.11 & 0.225 & 0.305 & 0.360 & 80 & 95 & 64 & 59.5 & 71.115 \\
\hline 55 & 2 & 0.11 & 0.275 & 0.285 & 0.330 & 80 & 95 & 64 & 59.5 & 72.800 \\
\hline 56 & 2 & 0.09 & 0.265 & 0.270 & 0.375 & 80 & 95 & 64 & 59.5 & 71.968 \\
\hline 57 & 2 & 0.09 & 0.245 & 0.330 & 0.335 & 80 & 95 & 64 & 59.5 & 71.528 \\
\hline 58 & 2 & 0.11 & 0.255 & 0.270 & 0.365 & 80 & 95 & 64 & 59.5 & 72.023 \\
\hline 59 & 2 & 0.11 & 0.235 & 0.330 & 0.325 & 80 & 95 & 64 & 59.5 & 71.583 \\
\hline 60 & 2 & 0.09 & 0.270 & 0.325 & 0.315 & 80 & 95 & 64 & 59.5 & 72.393 \\
\hline 61 & 2 & 0.09 & 0.240 & 0.285 & 0.385 & 80 & 95 & 64 & 59.5 & 71.148 \\
\hline 62 & 2 & 0.11 & 0.260 & 0.315 & 0.315 & 80 & 95 & 64 & 59.5 & 72.403 \\
\hline 63 & 2 & 0.11 & 0.230 & 0.275 & 0.385 & 80 & 95 & 64 & 59.5 & 71.158 \\
\hline 64 & 2 & 0.10 & 0.225 & 0.330 & 0.345 & 80 & 95 & 64 & 59.5 & 71.023 \\
\hline 65 & 2 & 0.10 & 0.275 & 0.270 & 0.355 & 80 & 95 & 64 & 59.5 & 72.528 \\
\hline 66 & 2 & 0.10 & 0.225 & 0.290 & 0.385 & 80 & 95 & 64 & 59.5 & 70.843 \\
\hline 67 & 2 & 0.10 & 0.275 & 0.310 & 0.315 & 80 & 95 & 64 & 59.5 & 72.708 \\
\hline 68 & 2 & 0.10 & 0.245 & 0.270 & 0.385 & 80 & 95 & 64 & 59.5 & 71.463 \\
\hline 69 & 2 & 0.10 & 0.255 & 0.330 & 0.315 & 80 & 95 & 64 & 59.5 & 72.088 \\
\hline 70 & 2 & 0.09 & 0.253 & 0.303 & 0.353 & 80 & 95 & 64 & 59.5 & 71.703 \\
\hline 71 & 2 & 0.11 & 0.247 & 0.297 & 0.347 & 80 & 95 & 64 & 59.5 & 71.847 \\
\hline 72 & 2 & 0.10 & 0.225 & 0.310 & 0.365 & 80 & 95 & 64 & 59.5 & 70.933 \\
\hline 73 & 2 & 0.10 & 0.275 & 0.290 & 0.335 & 80 & 95 & 64 & 59.5 & 72.618 \\
\hline 74 & 2 & 0.10 & 0.260 & 0.270 & 0.370 & 80 & 95 & 64 & 59.5 & 71.995 \\
\hline 75 & 2 & 0.10 & 0.240 & 0.330 & 0.330 & 80 & 95 & 64 & 59.5 & 71.555 \\
\hline 76 & 2 & 0.10 & 0.265 & 0.320 & 0.315 & 80 & 95 & 64 & 59.5 & 72.398 \\
\hline 77 & 2 & 0.10 & 0.235 & 0.280 & 0.385 & 80 & 95 & 64 & 59.5 & 71.153 \\
\hline 78 & 2 & 0.10 & 0.250 & 0.300 & 0.350 & 80 & 95 & 64 & 59.5 & 71.775 \\
\hline 79 & 3 & 0.11 & 0.275 & 0.270 & 0.345 & 60 & 90 & 62 & 24.7 & 56.612 \\
\hline 80 & 3 & 0.11 & 0.275 & 0.300 & 0.315 & 60 & 90 & 62 & 24.7 & 57.731 \\
\hline 81 & 3 & 0.11 & 0.225 & 0.330 & 0.335 & 60 & 90 & 62 & 24.7 & 55.585 \\
\hline 82 & 3 & 0.11 & 0.225 & 0.280 & 0.385 & 60 & 90 & 62 & 24.7 & 53.720 \\
\hline 83 & 3 & 0.11 & 0.245 & 0.330 & 0.315 & 60 & 90 & 62 & 24.7 & 56.891 \\
\hline 84 & 3 & 0.11 & 0.235 & 0.270 & 0.385 & 60 & 90 & 62 & 24.7 & 54.000 \\
\hline 85 & 3 & 0.09 & 0.275 & 0.270 & 0.365 & 60 & 90 & 62 & 24.7 & 55.906 \\
\hline 86 & 3 & 0.09 & \begin{tabular}{|l|l|} 
\\
\end{tabular} & 0.320 & 0.315 & 60 & 90 & 62 & 24.7 & 57.771 \\
\hline 87 & 3 & 0.09 & 0.225 & 0.330 & 0.355 & 60 & 90 & 62 & 24.7 & 54.879 \\
\hline 88 & 3 & 0.09 & 0.225 & 0.300 & 0.385 & 60 & 90 & 62 & 24.7 & 53.760 \\
\hline 89 & 3 & 0.09 & 0.265 & 0.330 & 0.315 & 60 & 90 & 62 & 24.7 & 57.491 \\
\hline 90 & 3 & 0.09 & 0.255 & 0.270 & 0.385 & 60 & 90 & 62 & 24.7 & 54.600 \\
\hline
\end{tabular}




\begin{tabular}{|c|c|c|c|c|c|c|c|c|c|c|}
\hline 91 & 3 & 0.09 & 0.225 & 0.315 & 0.370 & 60 & 90 & 62 & 24.7 & 54.319 \\
\hline 92 & 3 & 0.09 & 0.275 & 0.295 & 0.340 & 60 & 90 & 62 & 24.7 & 56.838 \\
\hline 93 & 3 & 0.11 & 0.225 & 0.305 & 0.360 & 60 & 90 & 62 & 24.7 & 54.652 \\
\hline 94 & 3 & 0.11 & 0.275 & 0.285 & 0.330 & 60 & 90 & 62 & 24.7 & 57.171 \\
\hline 95 & 3 & 0.09 & 0.265 & 0.270 & 0.375 & 60 & 90 & 62 & 24.7 & 55.253 \\
\hline 96 & 3 & 0.09 & 0.245 & 0.330 & 0.335 & 60 & 90 & 62 & 24.7 & 56.185 \\
\hline 97 & 3 & 0.11 & 0.255 & 0.270 & 0.365 & 60 & 90 & 62 & 24.7 & 55.306 \\
\hline 98 & 3 & 0.11 & 0.235 & 0.330 & 0.325 & 60 & 90 & 62 & 24.7 & 56.238 \\
\hline 99 & 3 & 0.09 & 0.270 & 0.325 & 0.315 & 60 & 90 & 62 & 24.7 & 57.631 \\
\hline 100 & 3 & 0.09 & 0.240 & 0.285 & 0.385 & 60 & 90 & 62 & 24.7 & 54.180 \\
\hline 101 & 3 & 0.11 & 0.260 & 0.315 & 0.315 & 60 & 90 & 62 & 24.7 & 57.311 \\
\hline 102 & 3 & 0.11 & 0.230 & 0.275 & 0.385 & 60 & 90 & 62 & 24.7 & 53.860 \\
\hline 103 & 3 & 0.10 & 0.225 & 0.330 & 0.345 & 60 & 90 & 62 & 24.7 & 55.232 \\
\hline 104 & 3 & 0.10 & 0.275 & 0.270 & 0.355 & 60 & 90 & 62 & 24.7 & 56.259 \\
\hline 105 & 3 & 0.10 & 0.225 & 0.290 & 0.385 & 60 & 90 & 62 & 24.7 & 53.740 \\
\hline 106 & 3 & 0.10 & 0.275 & 0.310 & 0.315 & 60 & 90 & 62 & 24.7 & 57.751 \\
\hline 107 & 3 & 0.10 & 0.245 & 0.270 & 0.385 & 60 & 90 & 62 & 24.7 & 54.300 \\
\hline 108 & 3 & 0.10 & 0.255 & 0.330 & 0.315 & 60 & 90 & 62 & 24.7 & 57.191 \\
\hline 109 & 3 & 0.09 & 0.253 & 0.303 & 0.353 & 60 & 90 & 62 & 24.7 & 55.734 \\
\hline 110 & 3 & 0.11 & 0.247 & 0.297 & 0.347 & 60 & 90 & 62 & 24.7 & 55.756 \\
\hline 111 & 3 & 0.10 & 0.225 & 0.310 & 0.365 & 60 & 90 & 62 & 24.7 & 54.486 \\
\hline 112 & 3 & 0.10 & 0.275 & 0.290 & 0.335 & 60 & 90 & 62 & 24.7 & 57.005 \\
\hline 113 & 3 & 0.10 & 0.260 & 0.270 & 0.370 & 60 & 90 & 62 & 24.7 & 55.279 \\
\hline 114 & 3 & 0.10 & 0.240 & 0.330 & 0.330 & 60 & 90 & 62 & 24.7 & 56.211 \\
\hline 115 & 3 & 0.10 & 0.265 & 0.320 & 0.315 & 60 & 90 & 62 & 24.7 & 57.471 \\
\hline 116 & 3 & 0.10 & 0.235 & 0.280 & 0.385 & 60 & 90 & 62 & 24.7 & 54.020 \\
\hline 117 & 3 & 0.10 & 0.250 & 0.300 & 0.350 & 60 & 90 & 62 & 24.7 & 55.745 \\
\hline 118 & 4 & 0.11 & 0.275 & 0.270 & 0.345 & 60 & 95 & 38 & 40.4 & 56.923 \\
\hline 119 & 4 & 0.11 & 0.275 & 0.300 & 0.315 & 60 & 95 & 38 & 40.4 & 56.851 \\
\hline 120 & 4 & 0.11 & 0.225 & 0.330 & 0.335 & 60 & 95 & 38 & 40.4 & 54.049 \\
\hline 121 & 4 & 0.11 & 0.225 & 0.280 & 0.385 & 60 & 95 & 38 & 40.4 & 54.169 \\
\hline 122 & 4 & 0.11 & 0.245 & 0.330 & 0.315 & 60 & 95 & 38 & 40.4 & 55.141 \\
\hline 123 & 4 & 0.11 & 0.235 & 0.270 & 0.385 & 60 & 95 & 38 & 40.4 & 54.739 \\
\hline 124 & 4 & 0.09 & 0.275 & 0.270 & 0.365 & 60 & 95 & 38 & 40.4 & 56.531 \\
\hline 125 & 4 & 0.09 & 0.275 & 0.320 & 0.315 & 60 & 95 & 38 & 40.4 & 56.411 \\
\hline 126 & 4 & 0.09 & 0.225 & 0.330 & 0.355 & 60 & 95 & 38 & 40.4 & 53.657 \\
\hline 127 & 4 & 0.09 & 0.225 & 0.300 & 0.385 & 60 & 95 & 38 & 40.4 & 53.729 \\
\hline 128 & 4 & 0.09 & 0.265 & 0.330 & 0.315 & 60 & 95 & 38 & 40.4 & 55.841 \\
\hline 129 & 4 & 0.09 & 0.255 & 0.270 & 0.385 & 60 & 95 & 38 & 40.4 & 55.439 \\
\hline 130 & 4 & 0.09 & 0.225 & 0.315 & 0.370 & 60 & 95 & 38 & 40.4 & 53.693 \\
\hline 131 & 4 & 0.09 & 0.275 & 0.295 & 0.340 & 60 & 95 & 38 & 40.4 & 56.471 \\
\hline 132 & 4 & 0.11 & 0.225 & 0.305 & 0.360 & 60 & 95 & 38 & 40.4 & 54.109 \\
\hline 133 & 4 & 0.11 & 0.275 & 0.285 & 0.330 & 60 & 95 & 38 & 40.4 & 56.887 \\
\hline 134 & 4 & 0.09 & 0.265 & 0.270 & 0.375 & 60 & 95 & 38 & 40.4 & 55.985 \\
\hline 135 & 4 & 0.09 & 0.245 & 0.330 & 0.335 & 60 & 95 & 38 & 40.4 & 54.749 \\
\hline 136 & 4 & 0.11 & 0.255 & 0.270 & 0.365 & 60 & 95 & 38 & 40.4 & 55.831 \\
\hline 137 & 4 & 0.11 & 0.235 & 0.330 & 0.325 & 60 & 95 & 38 & 40.4 & 54.595 \\
\hline 138 & 4 & 0.09 & 0.270 & 0.325 & 0.315 & 60 & 95 & 38 & 40.4 & 56.126 \\
\hline 139 & 4 & 0.09 & 0.240 & 0.285 & 0.385 & 60 & 95 & 38 & 40.4 & 54.584 \\
\hline
\end{tabular}




\begin{tabular}{|c|c|c|c|c|c|c|c|c|c|c|}
\hline 140 & 4 & 0.11 & 0.260 & 0.315 & 0.315 & 60 & 95 & 38 & 40.4 & 55.996 \\
\hline 141 & 4 & 0.11 & 0.230 & 0.275 & 0.385 & 60 & 95 & 38 & 40.4 & 54.454 \\
\hline 142 & 4 & 0.10 & 0.225 & 0.330 & 0.345 & 60 & 95 & 38 & 40.4 & 53.853 \\
\hline 143 & 4 & 0.10 & 0.275 & 0.270 & 0.355 & 60 & 95 & 38 & 40.4 & 56.727 \\
\hline 144 & 4 & 0.10 & 0.225 & 0.290 & 0.385 & 60 & 95 & 38 & 40.4 & 53.949 \\
\hline 145 & 4 & 0.10 & 0.275 & 0.310 & 0.315 & 60 & 95 & 38 & 40.4 & 56.631 \\
\hline 146 & 4 & 0.10 & 0.245 & 0.270 & 0.385 & 60 & 95 & 38 & 40.4 & 55.089 \\
\hline 147 & 4 & 0.10 & 0.255 & 0.330 & 0.315 & 60 & 95 & 38 & 40.4 & 55.491 \\
\hline 148 & 4 & 0.09 & 0.253 & 0.303 & 0.353 & 60 & 95 & 38 & 40.4 & 55.268 \\
\hline 149 & 4 & 0.11 & 0.247 & 0.297 & 0.347 & 60 & 95 & 38 & $\overrightarrow{40.4}$ & 55.312 \\
\hline 150 & 4 & 0.10 & 0.225 & 0.310 & 0.365 & 60 & 95 & 38 & \begin{tabular}{|l|}
40.4 \\
\end{tabular} & 53.901 \\
\hline 151 & 4 & 0.10 & 0.275 & 0.290 & 0.335 & 60 & 95 & 38 & 40.4 & 56.679 \\
\hline 152 & 4 & 0.10 & 0.260 & 0.270 & 0.370 & 60 & 95 & 38 & 40.4 & 55.908 \\
\hline 153 & 4 & 0.10 & 0.240 & 0.330 & 0.330 & 60 & 95 & 38 & 40.4 & 54.672 \\
\hline 154 & 4 & 0.10 & 0.265 & 0.320 & 0.315 & 60 & 95 & 38 & 40.4 & 56.061 \\
\hline 155 & 4 & 0.10 & 0.235 & 0.280 & 0.385 & 60 & 95 & 38 & 40.4 & 54.519 \\
\hline 156 & 4 & 0.10 & 0.250 & 0.300 & 0.350 & 60 & 95 & 38 & 40.4 & 55.290 \\
\hline 157 & 5 & 0.11 & 0.275 & 0.270 & 0.345 & 100 & 95 & 51 & 53.3 & 69.284 \\
\hline 158 & 5 & 0.11 & 0.275 & 0.300 & $\overline{0.315}$ & 100 & 95 & 51 & 53.3 & 69.215 \\
\hline 159 & 5 & 0.11 & 0.225 & 0.330 & 0.335 & 100 & 95 & 51 & 53.3 & 67.061 \\
\hline 160 & 5 & 0.11 & 0.225 & 0.280 & 0.385 & 100 & 95 & 51 & 53.3 & 67.176 \\
\hline 161 & 5 & 0.11 & 0.245 & 0.330 & 0.315 & 100 & 95 & 51 & \begin{tabular}{|l|}
53.3 \\
\end{tabular} & 67.895 \\
\hline 162 & 5 & 0.11 & 0.235 & 0.270 & 0.385 & 100 & 95 & 51 & 53.3 & 67.616 \\
\hline 163 & 5 & 0.09 & 0.275 & 0.270 & 0.365 & 100 & 95 & 51 & \begin{tabular}{|l|}
53.3 \\
\end{tabular} & 68.350 \\
\hline 164 & 5 & 0.09 & 0.275 & 0.320 & 0.315 & 100 & 95 & 51 & 53.3 & 68.235 \\
\hline 165 & 5 & 0.09 & 0.225 & 0.330 & 0.355 & 100 & 95 & 51 & 53.3 & 66.127 \\
\hline 166 & 5 & 0.09 & 0.225 & 0.300 & 0.385 & 100 & 95 & 51 & 53.3 & 66.196 \\
\hline 167 & 5 & 0.09 & 0.265 & 0.330 & 0.315 & 100 & 95 & 51 & 53.3 & 67.795 \\
\hline 168 & 5 & 0.09 & 0.255 & 0.270 & 0.385 & 100 & 95 & 51 & 53.3 & 67.516 \\
\hline 169 & 5 & 0.09 & 0.225 & 0.315 & 0.370 & 100 & 95 & 51 & 53.3 & 66.161 \\
\hline 170 & 5 & 0.09 & 0.275 & 0.295 & 0.340 & 100 & 95 & 51 & 53.3 & 68.292 \\
\hline 171 & 5 & 0.11 & 0.225 & 0.305 & 0.360 & 100 & 95 & 51 & 53.3 & 67.118 \\
\hline 172 & 5 & 0.11 & 0.275 & 0.285 & 0.330 & 100 & 95 & 51 & 53.3 & 69.249 \\
\hline 173 & 5 & 0.09 & 0.265 & 0.270 & 0.375 & 100 & 95 & 51 & 53.3 & 67.933 \\
\hline 174 & 5 & 0.09 & 0.245 & 0.330 & 0.335 & 100 & 95 & 51 & 53.3 & 66.961 \\
\hline 175 & 5 & 0.11 & 0.255 & 0.270 & 0.365 & 100 & 95 & 51 & 53.3 & 68.450 \\
\hline 176 & 5 & 0.11 & 0.235 & 0.330 & 0.325 & 100 & 95 & 51 & 53.3 & 67.478 \\
\hline 177 & 5 & 0.09 & 0.270 & 0.325 & 0.315 & 100 & 95 & 51 & 53.3 & 68.015 \\
\hline 178 & 5 & 0.09 & 0.240 & 0.285 & 0.385 & 100 & 95 & 51 & 53.3 & 66.856 \\
\hline 179 & 5 & 0.11 & 0.260 & 0.315 & 0.315 & 100 & 95 & 51 & 53.3 & 68.555 \\
\hline 180 & 5 & 0.11 & 0.230 & 0.275 & 0.385 & 100 & 95 & 51 & 53.3 & 67.396 \\
\hline 181 & 5 & 0.10 & 0.225 & 0.330 & 0.345 & 100 & 95 & 51 & 53.3 & 66.594 \\
\hline 182 & 5 & 0.10 & 0.275 & 0.270 & 0.355 & 100 & 95 & 51 & 53.3 & 68.817 \\
\hline 183 & 5 & 0.10 & 0.225 & 0.290 & 0.385 & 100 & 95 & 51 & 53.3 & 66.686 \\
\hline 184 & 5 & 0.10 & 0.275 & 0.310 & 0.315 & 100 & 95 & 51 & 53.3 & 68.725 \\
\hline 185 & 5 & 0.10 & 0.245 & 0.270 & 0.385 & 100 & 95 & 51 & 53.3 & 67.566 \\
\hline 186 & 5 & 0.10 & 0.255 & 0.330 & 0.315 & 100 & 95 & 51 & 53.3 & 67.845 \\
\hline 187 & 5 & 0.09 & 0.253 & 0.303 & 0.353 & 100 & 95 & 51 & 53.3 & 67.369 \\
\hline 188 & 5 & 0.11 & 0.247 & 0.297 & 0.347 & 100 & 95 & 51 & 53.3 & 68.041 \\
\hline
\end{tabular}




\begin{tabular}{|c|c|c|c|c|c|c|c|c|c|c|}
\hline 189 & 5 & 0.10 & 0.225 & 0.310 & 0.365 & 100 & 95 & 51 & 53.3 & 66.640 \\
\hline 190 & 5 & 0.10 & 0.275 & 0.290 & 0.335 & 100 & 95 & 51 & 53.3 & 68.771 \\
\hline 191 & 5 & 0.10 & 0.260 & 0.270 & \begin{tabular}{|l|}
0.370 \\
\end{tabular} & 100 & 95 & 51 & 53.3 & 68.191 \\
\hline 192 & 5 & 0.10 & 0.240 & 0.330 & 0.330 & 100 & 95 & 51 & 53.3 & 67.219 \\
\hline 193 & 5 & 0.10 & 0.265 & 0.320 & \begin{tabular}{|l|}
0.315 \\
\end{tabular} & 100 & 95 & 51 & 53.3 & 68.285 \\
\hline 194 & 5 & 0.10 & 0.235 & 0.280 & 0.385 & 100 & 95 & 51 & 53.3 & 67.126 \\
\hline 195 & 5 & 0.10 & 0.250 & 0.300 & 0.350 & 100 & 95 & 51 & 53.3 & 67.705 \\
\hline 196 & 6 & 0.11 & 0.275 & 0.270 & \begin{tabular}{|l|}
0.345 \\
\end{tabular} & 100 & 81 & 60 & 50 & 66.725 \\
\hline 197 & 6 & 0.11 & 0.275 & 0.300 & 0.315 & 100 & 81 & 60 & 50 & 67.025 \\
\hline 198 & 6 & 0.11 & 0.225 & 0.330 & 0.335 & 100 & 81 & 60 & 50 & 65.775 \\
\hline 199 & 6 & 0.11 & 0.225 & 0.280 & 0.385 & 100 & 81 & 60 & 50 & 65.275 \\
\hline 200 & 6 & 0.11 & 0.245 & 0.330 & 0.315 & 100 & 81 & 60 & 50 & 66.395 \\
\hline 201 & 6 & 0.11 & 0.235 & 0.270 & \begin{tabular}{|l|}
0.385 \\
\end{tabular} & 100 & 81 & 60 & 50 & 65.485 \\
\hline 202 & 6 & 0.09 & 0.275 & 0.270 & 0.365 & 100 & 81 & 60 & 50 & 65.725 \\
\hline 203 & 6 & 0.09 & 0.275 & 0.320 & 0.315 & 100 & 81 & 60 & 50 & 66.225 \\
\hline 204 & 6 & 0.09 & 0.225 & 0.330 & 0.355 & 100 & 81 & 60 & 50 & 64.775 \\
\hline 205 & 6 & 0.09 & 0.225 & 0.300 & 0.385 & 100 & 81 & 60 & 50 & 64.475 \\
\hline 206 & 6 & 0.09 & 0.265 & 0.330 & 0.315 & 100 & 81 & 60 & 50 & 66.015 \\
\hline 207 & 6 & 0.09 & 0.255 & 0.270 & 0.385 & 100 & 81 & 60 & 50 & 65.105 \\
\hline 208 & 6 & 0.09 & 0.225 & 0.315 & 0.370 & 100 & 81 & 60 & 50 & 64.625 \\
\hline 209 & 6 & 0.09 & 0.275 & 0.295 & 0.340 & 100 & 81 & 60 & 50 & 65.975 \\
\hline 210 & 6 & 0.11 & 0.225 & 0.305 & 0.360 & 100 & 81 & 60 & 50 & 65.525 \\
\hline 211 & 6 & 0.11 & 0.275 & 0.285 & 0.330 & 100 & 81 & 60 & 50 & 66.875 \\
\hline 212 & 6 & 0.09 & 0.265 & 0.270 & 0.375 & 100 & 81 & 60 & 50 & 65.415 \\
\hline 213 & 6 & 0.09 & 0.245 & 0.330 & 0.335 & 100 & 81 & 60 & 50 & 65.395 \\
\hline 214 & 6 & 0.11 & 0.255 & 0.270 & 0.365 & 100 & 81 & 60 & 50 & 66.105 \\
\hline 215 & 6 & 0.11 & 0.235 & 0.330 & 0.325 & 100 & 81 & 60 & 50 & 66.085 \\
\hline 216 & 6 & 0.09 & 0.270 & 0.325 & 0.315 & 100 & 81 & 60 & 50 & 66.120 \\
\hline 217 & 6 & 0.09 & 0.240 & 0.285 & 0.385 & 100 & 81 & 60 & 50 & 64.790 \\
\hline 218 & 6 & 0.11 & 0.260 & 0.315 & 0.315 & 100 & 81 & 60 & 50 & 66.710 \\
\hline 219 & 6 & 0.11 & 0.230 & 0.275 & 0.385 & 100 & 81 & 60 & 50 & 65.380 \\
\hline 220 & 6 & 0.10 & 0.225 & 0.330 & 0.345 & 100 & 81 & 60 & 50 & 65.275 \\
\hline 221 & 6 & 0.10 & 0.275 & \begin{tabular}{|l|}
0.270 \\
\end{tabular} & 0.355 & 100 & 81 & 60 & 50 & 66.225 \\
\hline 222 & 6 & 0.10 & 0.225 & 0.290 & 0.385 & 100 & 81 & 60 & 50 & 64.875 \\
\hline 223 & 6 & 0.10 & 0.275 & 0.310 & 0.315 & 100 & 81 & 60 & 50 & 66.625 \\
\hline 224 & 6 & 0.10 & 0.245 & 0.270 & 0.385 & 100 & 81 & 60 & 50 & 65.295 \\
\hline 225 & 6 & 0.10 & 0.255 & 0.330 & 0.315 & 100 & 81 & 60 & 50 & 66.205 \\
\hline 226 & 6 & 0.09 & 0.253 & 0.303 & 0.353 & 100 & 81 & 60 & 50 & 65.387 \\
\hline 227 & 6 & 0.11 & 0.247 & \begin{tabular}{|l|}
0.297 \\
\end{tabular} & 0.347 & 100 & 81 & 60 & 50 & 66.113 \\
\hline 228 & 6 & 0.10 & 0.225 & 0.310 & 0.365 & 100 & 81 & 60 & 50 & 65.075 \\
\hline 229 & 6 & 0.10 & 0.275 & 0.290 & 0.335 & 100 & 81 & 60 & 50 & 66.425 \\
\hline 230 & 6 & 0.10 & 0.260 & \begin{tabular}{|l}
0.270 \\
\end{tabular} & 0.370 & 100 & 81 & 60 & 50 & 65.760 \\
\hline 231 & 6 & 0.10 & 0.240 & \begin{tabular}{|l}
0.330 \\
\end{tabular} & 0.330 & 100 & 81 & 60 & 50 & 65.740 \\
\hline 232 & 6 & 0.10 & 0.265 & \begin{tabular}{|l}
0.320 \\
\end{tabular} & 0.315 & 100 & 81 & 60 & 50 & 66.415 \\
\hline 233 & 6 & 0.10 & 0.235 & 0.280 & 0.385 & 100 & 81 & 60 & 50 & 65.085 \\
\hline 234 & 6 & 0.10 & 0.250 & 0.300 & 0.350 & 100 & 81 & 60 & 50 & 65.750 \\
\hline 235 & 7 & 0.11 & 0.275 & 0.270 & 0.345 & 80 & 85 & 64 & 39 & 62.910 \\
\hline 236 & 7 & 0.11 & 0.275 & 0.300 & 0.315 & 80 & 85 & 64 & 39 & 63.660 \\
\hline 237 & 7 & 0.11 & 0.225 & 0.330 & 0.335 & 80 & $\overline{85}$ & 64 & 39 & 62.110 \\
\hline
\end{tabular}




\begin{tabular}{|c|c|c|c|c|c|c|c|c|c|c|}
\hline 238 & 7 & 0.11 & 0.225 & 0.280 & 0.385 & 80 & 85 & 64 & 39 & 60.860 \\
\hline 239 & 7 & 0.11 & 0.245 & 0.330 & 0.315 & 80 & 85 & 64 & 39 & 63.030 \\
\hline 240 & 7 & 0.11 & 0.235 & 0.270 & \begin{tabular}{|l|}
0.385 \\
\end{tabular} & 80 & 85 & 64 & 39 & 61.070 \\
\hline 241 & 7 & 0.09 & 0.275 & 0.270 & 0.365 & 80 & 85 & 64 & 39 & 62.090 \\
\hline 242 & 7 & 0.09 & 0.275 & 0.320 & 0.315 & 80 & 85 & 64 & 39 & 63.340 \\
\hline 243 & 7 & 0.09 & 0.225 & 0.330 & 0.355 & 80 & 85 & 64 & 39 & 61.290 \\
\hline 244 & 7 & 0.09 & 0.225 & 0.300 & 0.385 & .80 & 85 & 64 & 39 & 60.540 \\
\hline 245 & 7 & 0.09 & 0.265 & 0.330 & 0.315 & 80 & 85 & 64 & 39 & 63.130 \\
\hline 246 & 7 & 0.09 & 0.255 & 0.270 & 0.385 & 80 & 85 & 64 & 39 & 61.170 \\
\hline 247 & 7 & 0.09 & 0.225 & 0.315 & 0.370 & 80 & 85 & 64 & 39 & 60.915 \\
\hline 248 & 7 & 0.09 & 0.275 & 0.295 & 0.340 & 80 & 85 & 64 & 39 & 62.715 \\
\hline 249 & 7 & 0.11 & 0.225 & 0.305 & 0.360 & 80 & 85 & 64 & 39 & 61.485 \\
\hline 250 & 7 & 0.11 & 0.275 & 0.285 & 0.330 & 80 & 85 & 64 & 39 & 63.285 \\
\hline 251 & 7 & 0.09 & 0.265 & 0.270 & 0.375 & 80 & 85 & 64 & 39 & 61.630 \\
\hline 252 & 7 & 0.09 & 0.245 & 0.330 & 0.335 & 80 & 85 & 64 & 39 & 62.210 \\
\hline 253 & 7 & 0.11 & 0.255 & 0.270 & 0.365 & 80 & 85 & 64 & 39 & 61.990 \\
\hline 254 & 7 & 0.11 & 0.235 & 0.330 & 0.325 & 80 & 85 & 64 & 39 & 62.570 \\
\hline 255 & 7 & 0.09 & 0.270 & 0.325 & 0.315 & 80 & 85 & 64 & 39 & 63.235 \\
\hline 256 & 7 & 0.09 & 0.240 & 0.285 & 0.385 & 80 & 85 & 64 & 39 & 60.855 \\
\hline 257 & 7 & 0.11 & 0.260 & 0.315 & 0.315 & 80 & 85 & 64 & 39 & 63.345 \\
\hline 258 & 7 & 0.11 & 0.230 & 0.275 & 0.385 & 80 & 85 & 64 & 39 & 60.965 \\
\hline 259 & 7 & 0.10 & 0.225 & 0.330 & 0.345 & 80 & 85 & 64 & 39 & 61.700 \\
\hline 260 & 7 & 0.10 & 0.275 & 0.270 & 0.355 & 80 & 85 & 64 & 39 & 62.500 \\
\hline 261 & 7 & 0.10 & 0.225 & 0.290 & 0.385 & 80 & 85 & 64 & 39 & 60.700 \\
\hline 262 & 7 & 0.10 & 0.275 & 0.310 & \begin{tabular}{|l|l|}
0.315 \\
\end{tabular} & 80 & 85 & 64 & 39 & 63.500 \\
\hline 263 & 7 & 0.10 & 0.245 & 0.270 & 0.385 & 80 & 85 & 64 & 39 & 61.120 \\
\hline 264 & 7 & 0.10 & 0.255 & 0.330 & 0.315 & 80 & 85 & 64 & 39 & 63.080 \\
\hline 265 & 7 & 0.09 & 0.253 & 0.303 & \begin{tabular}{|l|}
0.353 \\
\end{tabular} & 80 & 85 & 64 & 39 & 61.927 \\
\hline 266 & 7 & 0.11 & 0.247 & 0.297 & 0.347 & 80 & 85 & 64 & 39 & 62.273 \\
\hline 267 & 7 & 0.10 & 0.225 & 0.310 & 0.365 & 80 & 85 & 64 & 39 & 61.200 \\
\hline 268 & 7 & 0.10 & 0.275 & 0.290 & 0.335 & 80 & 85 & 64 & 39 & 63.000 \\
\hline 269 & 7 & 0.10 & 0.260 & 0.270 & 0.370 & 80 & 85 & 64 & 39 & 61.810 \\
\hline 270 & 7 & 0.10 & 0.240 & 0.330 & 0.330 & 80 & 85 & 64 & 39 & 62.390 \\
\hline 271 & 7 & 0.10 & 0.265 & 0.320 & 0.315 & 80 & 85 & 64 & 39 & 63.290 \\
\hline 272 & 7 & 0.10 & 0.235 & 0.280 & \begin{tabular}{|l|l|}
0.385 \\
\end{tabular} & 80 & 85 & 64 & 39 & 60.910 \\
\hline 273 & 7 & 0.10 & 0.250 & 0.300 & 0.350 & 80 & 85 & 64 & 39 & 62.100 \\
\hline 274 & A & 0.11 & 0.275 & 0.270 & 0.345 & 100 & 90 & $\overline{71}$ & 58.7 & 75.172 \\
\hline 275 & $\mathbf{A}$ & 0.11 & 0.275 & 0.300 & 0.315 & 100 & 90 & 71 & 58.7 & 75.541 \\
\hline 276 & A & 0.11 & 0.225 & 0.330 & 0.335 & 100 & 90 & 71 & 58.7 & 74.345 \\
\hline 277 & $\bar{A}$ & 0.11 & 0.225 & 0.280 & 0.385 & 100 & 90 & 71 & 58.7 & 73.730 \\
\hline 278 & $\mathbf{A}$ & 0.11 & 0.245 & 0.330 & 0.315 & 100 & 90 & 71 & 58.7 & 74.971 \\
\hline 279 & $\mathbf{A}$ & 0.11 & 0.235 & 0.270 & 0.385 & 100 & 90 & 71 & 58.7 & 73.920 \\
\hline 280 & $\mathbf{A}$ & 0.09 & 0.275 & 0.270 & 0.365 & 100 & 90 & 71 & 58.7 & 74.346 \\
\hline 281 & A & 0.09 & 0.275 & 0.320 & 0.315 & 100 & 90 & 71 & 58.7 & 74.961 \\
\hline 282 & A & 0.09 & 0.225 & 0.330 & 0.355 & 100 & 90 & 71 & 58.7 & 73.519 \\
\hline 283 & A & 0.09 & 0.225 & 0.300 & 0.385 & 100 & 90 & 71 & 58.7 & 73.150 \\
\hline 284 & $\mathbf{A}$ & 0.09 & 0.265 & 0.330 & 0.315 & 100 & 90 & $\overline{71}$ & 58.7 & 74.771 \\
\hline 285 & A & 0.09 & 0.255 & 0.270 & 0.385 & 100 & 90 & 71 & 58.7 & 73.720 \\
\hline 286 & $\bar{A}$ & 0.09 & 0.225 & 0.315 & \begin{tabular}{|l|}
0.370 \\
\end{tabular} & 100 & 90 & 71 & 58.7 & 73.334 \\
\hline
\end{tabular}




\begin{tabular}{|c|c|c|c|c|c|c|c|c|c|c|}
\hline 287 & A & 0.09 & 0.275 & 0.295 & 0.340 & 100 & 90 & 71 & 58.7 & 74.653 \\
\hline 288 & A) & 0.11 & 0.225 & 0.305 & 0.360 & 100 & 90 & 71 & 58.7 & 74.037 \\
\hline 289 & $\mathbf{A}$ & 0.11 & 0.275 & 0.285 & 0.330 & 100 & 90 & 71 & 58.7 & 75.356 \\
\hline 290 & A & 0.09 & 0.265 & 0.270 & 0.375 & 100 & 90 & 71 & 58.7 & 74.033 \\
\hline 291 & A & 0.09 & 0.245 & 0.330 & 0.335 & 100 & 90 & 71 & 58.7 & 74.145 \\
\hline 292 & A & 0.11 & 0.255 & 0.270 & 0.365 & 100 & 90 & 71 & 58.7 & 74.546 \\
\hline 293 & A & 0.11 & 0.235 & 0.330 & 0.325 & 100 & 90 & 71 & 58.7 & 74.658 \\
\hline 294 & A & 0.09 & 0.270 & 0.325 & 0.315 & 100 & 90 & 71 & 58.7 & 74.866 \\
\hline 295 & A & 0.09 & 0.240 & 0.285 & 0.385 & 100 & 90 & 71 & 58.7 & 73.435 \\
\hline 296 & A & 0.11 & 0.260 & 0.315 & 0.315 & 100 & 90 & 71 & 58.7 & 75.256 \\
\hline 297 & A & 0.11 & 0.230 & 0.275 & 0.385 & 100 & 90 & 71 & 58.7 & 73.825 \\
\hline 298 & A & 0.10 & 0.225 & 0.330 & 0.345 & 100 & 90 & 71 & 58.7 & 73.932 \\
\hline 299 & A & 0.10 & 0.275 & 0.270 & 0.355 & 100 & 90 & 71 & 58.7 & 74.759 \\
\hline 300 & A & 0.10 & 0.225 & 0.290 & 0.385 & 100 & 90 & 71 & 58.7 & 73.440 \\
\hline 301 & A & 0.10 & 0.275 & 0.310 & 0.315 & 100 & 90 & 71 & 58.7 & 75.251 \\
\hline 302 & A & 0.10 & 0.245 & 0.270 & 0.385 & 100 & 90 & 71 & 58.7 & 73.820 \\
\hline 303 & $\mathbf{A}$ & 0.10 & 0.255 & 0.330 & 0.315 & 100 & 90 & 71 & 58.7 & 74.871 \\
\hline 304 & A & 0.09 & 0.253 & 0.303 & 0.353 & 100 & 90 & 71 & 58.7 & 74.077 \\
\hline 305 & A & 0.11 & 0.247 & 0.297 & 0.347 & 100 & 90 & 71 & 58.7 & 74.613 \\
\hline 306 & $\mathbf{A}$ & 0.10 & 0.225 & 0.310 & 0.365 & 100 & 90 & 71 & 58.7 & 73.686 \\
\hline 307 & A & 0.10 & 0.275 & 0.290 & 0.335 & 100 & 90 & 71 & 58.7 & 75.005 \\
\hline 308 & A & 0.10 & 0.260 & 0.270 & 0.370 & 100 & 90 & 71 & 58.7 & 74.289 \\
\hline 309 & A & 0.10 & 0.240 & 0.330 & 0.330 & 100 & 90 & 71 & 58.7 & 74.401 \\
\hline 310 & A & 0.10 & 0.265 & 0.320 & 0.315 & 100 & 90 & 71 & 58.7 & 75.061 \\
\hline 311 & A & 0.10 & 0.235 & 0.280 & 0.385 & 100 & 90 & 71 & 58.7 & 73.630 \\
\hline 312 & A & 0.10 & 0.250 & 0.300 & 0.350 & 100 & 90 & 71 & 58.7 & 74.345 \\
\hline 313 & $\mathrm{x}$ & 0.11 & 0.275 & 0.270 & 0.345 & 100 & 94 & 66 & 59.3 & 75.129 \\
\hline 314 & $\mathbf{x}$ & 0.11 & 0.275 & 0.300 & 0.315 & 100 & 94 & 66 & 59.3 & 75.330 \\
\hline 315 & $\mathbf{x}$ & 0.11 & 0.225 & 0.330 & 0.335 & 100 & 94 & 66 & 59.3 & 73.796 \\
\hline 316 & $\mathrm{x}$ & 0.11 & 0.225 & 0.280 & 0.385 & 100 & 94 & 66 & 59.3 & 73.461 \\
\hline 317 & $\mathrm{X}$ & 0.11 & 0.245 & 0.330 & 0.315 & 100 & 94 & 66 & 59.3 & 74.490 \\
\hline 318 & $\mathbf{X}$ & 0.11 & 0.235 & 0.270 & 0.385 & 100 & 94 & 66 & 59.3 & 73.741 \\
\hline 319 & $\mathbf{x}$ & 0.09 & 0.275 & 0.270 & 0.365 & 100 & 94 & 66 & 59.3 & 74.315 \\
\hline 320 & $\mathbf{x}$ & 0.09 & 0.275 & 0.320 & 0.315 & 100 & 94 & 66 & 59.3 & 74.650 \\
\hline 321 & $\mathbf{X}$ & 0.09 & 0.225 & 0.330 & 0.355 & 100 & 94 & 66 & 59.3 & 72.982 \\
\hline 322 & $\mathbf{X}$ & 0.09 & 0.225 & 0.300 & 0.385 & 100 & 94 & 66 & 59.3 & 72.781 \\
\hline 323 & $\mathbf{X}$ & 0.09 & 0.265 & 0.330 & 0.315 & 100 & 94 & 66 & 59.3 & 74.370 \\
\hline 324 & $\mathrm{x}$ & 0.09 & 0.255 & 0.270 & 0.385 & 100 & 94 & 66 & 59.3 & 73.621 \\
\hline 325 & $\mathrm{X}$ & 0.09 & 0.225 & 0.315 & 0.370 & 100 & 94 & 66 & 59.3 & 72.881 \\
\hline 326 & $\mathrm{X}$ & 0.09 & 0.275 & 0.295 & 0.340 & 100 & 94 & 66 & 59.3 & 74.482 \\
\hline 327 & $\mathbf{X}$ & 0.11 & 0.225 & 0.305 & 0.360 & 100 & 94 & 66 & 59.3 & 73.628 \\
\hline 328 & $\mathbf{x}$ & 0.11 & 0.275 & 0.285 & 0.330 & 100 & 94 & 66 & 59.3 & 75.229 \\
\hline 329 & $\mathrm{x}$ & 0.09 & 0.265 & 0.270 & 0.375 & 100 & 94 & 66 & 59.3 & 73.968 \\
\hline 330 & $\mathbf{x}$ & 0.09 & 0.245 & 0.330 & 0.335 & 100 & 94 & 66 & 59.3 & 73.676 \\
\hline 331 & $\mathbf{x}$ & 0.11 & 0.255 & 0.270 & 0.365 & 100 & 94 & 66 & 59.3 & 74.435 \\
\hline 332 & $\mathbf{x}$ & 0.11 & 0.235 & 0.330 & 0.325 & 100 & 94 & 66 & 59.3 & 74.143 \\
\hline 333 & $\mathbf{x}$ & 0.09 & 0.270 & 0.325 & 0.315 & 100 & 94 & 66 & 59.3 & 74.510 \\
\hline 334 & $\mathbf{x}$ & 0.09 & 0.240 & 0.285 & 0.385 & 100 & 94 & 66 & 59.3 & 73.201 \\
\hline 335 & $\mathbf{x}$ & 0.11 & 0.260 & 0.315 & 0.315 & 100 & 94 & 66 & 59.3 & 74.910 \\
\hline
\end{tabular}




\begin{tabular}{|r|r|r|r|r|r|r|r|r|r|r|r|}
\hline $\mathbf{3 3 6}$ & $\mathbf{X}$ & 0.11 & 0.230 & 0.275 & 0.385 & & 100 & 94 & 66 & 59.3 & 73.601 \\
\hline $\mathbf{3 3 7}$ & $\mathbf{X}$ & 0.10 & 0.225 & 0.330 & 0.345 & & 100 & 94 & 66 & 59.3 & 73.389 \\
\hline $\mathbf{3 3 8}$ & $\mathbf{X}$ & 0.10 & 0.275 & 0.270 & 0.355 & & 100 & 94 & 66 & 59.3 & 74.722 \\
\hline $\mathbf{3 3 9}$ & $\mathbf{X}$ & 0.10 & 0.225 & 0.290 & 0.385 & & 100 & 94 & 66 & 59.3 & 73.121 \\
\hline $\mathbf{3 4 0}$ & $\mathbf{X}$ & 0.10 & 0.275 & 0.310 & 0.315 & & 100 & 94 & 66 & 59.3 & 74.990 \\
\hline $\mathbf{3 4 1}$ & $\mathbf{X}$ & 0.10 & 0.245 & 0.270 & 0.385 & & 100 & 94 & 66 & 59.3 & 73.681 \\
\hline $\mathbf{3 4 2}$ & $\mathbf{X}$ & 0.10 & 0.255 & 0.330 & 0.315 & & 100 & 94 & 66 & 59.3 & 74.430 \\
\hline $\mathbf{3 4 3}$ & $\mathbf{X}$ & 0.09 & 0.253 & 0.303 & 0.353 & & 100 & 94 & 66 & 59.3 & 73.786 \\
\hline $\mathbf{3 4 4}$ & $\mathbf{X}$ & 0.11 & 0.247 & 0.297 & 0.347 & & 100 & 94 & 66 & 59.3 & 74.324 \\
\hline $\mathbf{3 4 5}$ & $\mathbf{X}$ & 0.10 & 0.225 & 0.310 & 0.365 & & 100 & 94 & 66 & 59.3 & 73.255 \\
\hline $\mathbf{3 4 6}$ & $\mathbf{X}$ & 0.10 & 0.275 & 0.290 & 0.335 & & 100 & 94 & 66 & 59.3 & 74.856 \\
\hline $\mathbf{3 4 7}$ & $\mathbf{X}$ & 0.10 & 0.260 & 0.270 & 0.370 & & 100 & 94 & 66 & 59.3 & 74.201 \\
\hline $\mathbf{3 4 8}$ & $\mathbf{X}$ & 0.10 & 0.240 & 0.330 & 0.330 & & 100 & 94 & 66 & 59.3 & 73.909 \\
\hline $\mathbf{3 4 9}$ & $\mathbf{X}$ & 0.10 & 0.265 & 0.320 & 0.315 & & 100 & 94 & 66 & 59.3 & 74.710 \\
\hline $\mathbf{3 5 0}$ & $\mathbf{X}$ & 0.10 & 0.235 & 0.280 & 0.385 & & 100 & 94 & 66 & 59.3 & 73.401 \\
\hline $\mathbf{3 5 1}$ & $\mathbf{X}$ & 0.10 & 0.250 & 0.300 & 0.350 & & 100 & 94 & 66 & 59.3 & 74.055 \\
\hline
\end{tabular}


Table 3

\section{Summary Statistics}

$10 \%$ Change in Primary Weights

\begin{tabular}{lllll} 
Code & Count & Average & Median & $\begin{array}{l}\text { Standard } \\
\text { Deviation }\end{array}$ \\
\hline 1 & 39 & 74.6854 & 74.685 & 0.62484 \\
2 & 39 & 71.7754 & 71.775 & 0.660588 \\
3 & 39 & 55.7454 & 55.745 & 1.33784 \\
4 & 39 & 55.29 & 55.29 & 1.05016 \\
5 & 39 & 67.7054 & 67.705 & 0.851512 \\
6 & 39 & 65.75 & 65.75 & 0.654126 \\
7 & 39 & 62.1 & 62.1 & 0.941092 \\
A & 39 & 74.3454 & 74.345 & 0.636898 \\
X & 39 & 74.0554 & 74.055 & 0.678809 \\
- Total & 351 & 66.828 & 67.705 & 7.32596
\end{tabular}

$20 \%$ Change in Primary Weights standard

\begin{tabular}{lcccc} 
Code & Count & Average & Median & Deviation \\
\hline 1 & 39 & 74.685 & 74.685 & 1.24966 \\
2 & 39 & 71.775 & 71.775 & 1.32117 \\
3 & 39 & 55.745 & 55.745 & 2.67567 \\
4 & 39 & 55.29 & 55.29 & 2.10032 \\
5 & 39 & 67.705 & 67.705 & 1.703 \\
6 & 39 & 65.75 & 65.75 & 1.30828 \\
7 & 39 & 62.1 & 62.1 & 1.88219 \\
A & 39 & 74.345 & 74.345 & 1.27377 \\
X & 39 & 74.055 & 74.055 & 1.35762 \\
\hline Total & 351 & 66.8278 & 67.984 & 7.47168
\end{tabular}

$30 \%$ Change in Primary Weights

\begin{tabular}{|c|c|c|c|c|}
\hline Code & Count & Average & Median & $\begin{array}{l}\text { standard } \\
\text { Deviation }\end{array}$ \\
\hline \multicolumn{5}{|c|}{ 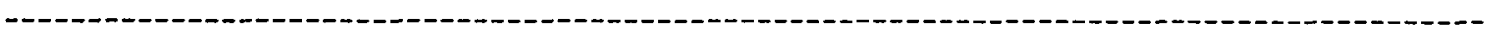 } \\
\hline 1 & 39 & 74.6854 & 74.685 & 1.8745 \\
\hline 2 & 39 & 71.7754 & 71.775 & 1.98176 \\
\hline 3 & 39 & 55.7454 & 55.745 & 4.01351 \\
\hline 4 & 39 & 55.29 & 55.29 & 3.15049 \\
\hline 5 & 39 & 67.7054 & 67.705 & 2.55452 \\
\hline 6 & 39 & 65.75 & 65.75 & 1.96241 \\
\hline 7 & 39 & 62.1 & 62.1 & 2.82329 \\
\hline$A$ & 39 & 74.3454 & 74.345 & 1.91067 \\
\hline $\mathrm{X}$ & 39 & 74.0554 & 74.055 & 2.03643 \\
\hline Potal & 351 & 66028 & 68388 & 770867 \\
\hline
\end{tabular}

40\% Change in Primary Weights

\begin{tabular}{lcccc} 
Code & Count & Average & Median & $\begin{array}{l}\text { Standard } \\
\text { Deviation }\end{array}$ \\
\hline 1 & 39 & 74.685 & 74.685 & 2.49933 \\
2 & 39 & 71.775 & 71.775 & 2.64234 \\
3 & 39 & 55.745 & 55.745 & 5.35134 \\
4 & 39 & 55.29 & 55.29 & 4.20065 \\
5 & 39 & 67.705 & 67.705 & 3.40602 \\
6 & 39 & 65.75 & 65.75 & 3.76438 \\
7 & 39 & 62.1 & 62.1 & 2.54756 \\
A & 39 & 74.345 & 74.345 & 2.71524 \\
-2 & 39 & 74.055 & 74.055 & 8.02849
\end{tabular}


Table 4

Analysis of Weighted Score Ranks

\section{$10 \%$ Change in Primary Weights}

Rank

Site

\begin{tabular}{|c|c|c|c|c|c|c|c|c|c|}
\hline & 1 & 2 & 3 & 4 & 5 & 6 & & \multicolumn{2}{|c|}{$X$} \\
\hline 1 & 24 & 0 & 0 & 0 & 0 & 0 & 0 & 15 & 0 \\
\hline 2 & 9 & 0 & 0 & 0 & 0 & 0 & 0 & 24 & 6 \\
\hline 3 & 6 & 0 & 0 & 0 & 0 & 0 & 0 & 0 & 33 \\
\hline 4 & 0 & 39 & 0 & 0 & 0 & 0 & 0 & 0 & 0 \\
\hline 5 & 0 & 0 & 0 & 0 & 39 & 0 & 0 & 0 & 0 \\
\hline 6 & 0 & 0 & 0 & 0 & 0 & 39 & 0 & 0 & 0 \\
\hline 7 & 0 & 0 & 0 & 0 & 0 & 0 & 39 & $\overline{0}$ & 0 \\
\hline 8 & 0 & 0 & 25 & 14 & 0 & 0 & 0 & 0 & 0 \\
\hline 9 & 0 & 0 & 14 & 25 & 0 & 0 & 0 & 0 & 0 \\
\hline & 39 & 39 & 39 & 39 & 39 & 39 & 39 & 39 & 39 \\
\hline
\end{tabular}

20\% Change in Primary Weights

\section{Rank}

\begin{tabular}{|c|c|c|c|c|c|c|c|c|c|}
\hline \multicolumn{10}{|c|}{ Site } \\
\hline & 1 & 2 & 3 & 4 & 5 & 6 & & & $\mathrm{X}$ \\
\hline 1 & 24 & 0 & 0 & 0 & 0 & 0 & 0 & 15 & 0 \\
\hline 2 & 2 & 0 & 0 & 0 & 0 & 0 & 0 & 15 & 22 \\
\hline 3 & 13 & 0 & 0 & 0 & 0 & 0 & 0 & 9 & 17 \\
\hline 4 & 0 & 39 & 0 & 0 & 0 & 0 & 0 & 0 & 0 \\
\hline 5 & 0 & 0 & 0 & 0 & 39 & 0 & 0 & 0 & 0 \\
\hline 6 & 0 & 0 & 0 & 0 & 0 & 39 & 0 & 0 & 0 \\
\hline 7 & 0 & 0 & 0 & 0 & 0 & 0 & 39 & 0 & 0 \\
\hline 8 & 0 & 0 & 24 & 15 & 0 & 0 & 0 & 0 & 0 \\
\hline 9) & 0 & 0 & 15 & 24 & 0 & 0 & 0 & 0 & 0 \\
\hline & 39 & 39 & 39 & 39 & 39 & 39 & 39 & 39 & 39 \\
\hline
\end{tabular}




\section{$30 \%$ Change in Primary Weights}

Rank

Site

\begin{tabular}{|c|c|c|c|c|c|c|c|c|}
\hline 1 & 2 & 3 & 4 & 5 & 6 & & \multicolumn{2}{|c|}{$\mathbf{X}$} \\
\hline 24 & 0 & 0 & 0 & 0 & 0 & 0 & 15 & 0 \\
\hline 1 & 0 & 0 & 0 & 0 & 0 & 0 & 12 & 26 \\
\hline 14 & 0 & 0 & 0 & 0 & 0 & 0 & 12 & 13 \\
\hline 0 & 39 & 0 & 0 & 0 & 0 & 0 & 0 & 0 \\
\hline 0 & 0 & 0 & 0 & 38 & 1 & 0 & 0 & 0 \\
\hline 0 & 0 & 0 & 0 & 1 & 38 & 0 & 0 & 0 \\
\hline 0 & 0 & 0 & 0 & 0 & 0 & 39 & 0 & 0 \\
\hline 0 & 0 & 23 & 16 & 0 & 0 & 0 & 0 & 0 \\
\hline 0 & 0 & 16 & 23 & 0 & 0 & 0 & 0 & 0 \\
\hline 39 & 39 & 39 & 39 & 39 & 39 & 39 & 39 & 39 \\
\hline
\end{tabular}

40\% Change in Primary Weights

Rank

\begin{tabular}{|c|c|c|c|c|c|c|c|c|c|c|}
\hline & & & & & & & & & & \\
\hline & 1 & 2 & 3 & 4 & 5 & 6 & & & & \\
\hline 1) & 24 & 0 & 0 & 0 & 0 & 0 & 0 & 14 & 1 & 39 \\
\hline 2 & 0 & 0 & 0 & 0 & 0 & 0 & 0 & 13 & 26 & 39 \\
\hline 3 & 12 & 3 & 0 & 0 & 0 & 0 & 0 & 12 & 12 & 39 \\
\hline 4 & 3 & 36 & 0 & 0 & 0 & 0 & 0 & 0 & 0 & 39 \\
\hline 5 & 0 & 0 & 0 & 0 & 35 & 4 & 0 & 0 & 0 & 39 \\
\hline 6 & 0 & 0 & 0 & 0 & 4 & 35 & 0 & 0 & $\overline{0}$ & 39 \\
\hline 7 & 0 & 0 & 0 & 0 & 0 & 0 & 39 & 0 & 0 & 39 \\
\hline 8 & 0 & 0 & 22 & 17 & 0 & 0 & 0 & 0 & 0 & 39 \\
\hline 9[ & 0 & 0 & 17 & 22 & 0 & 0 & 0 & 0 & 0 & 39 \\
\hline & 39 & 39 & 39 & 39 & 39 & 39 & 39 & 39 & 39 & 351 \\
\hline
\end{tabular}




\section{Plot 1}

\section{Box-and Whisker Plots}

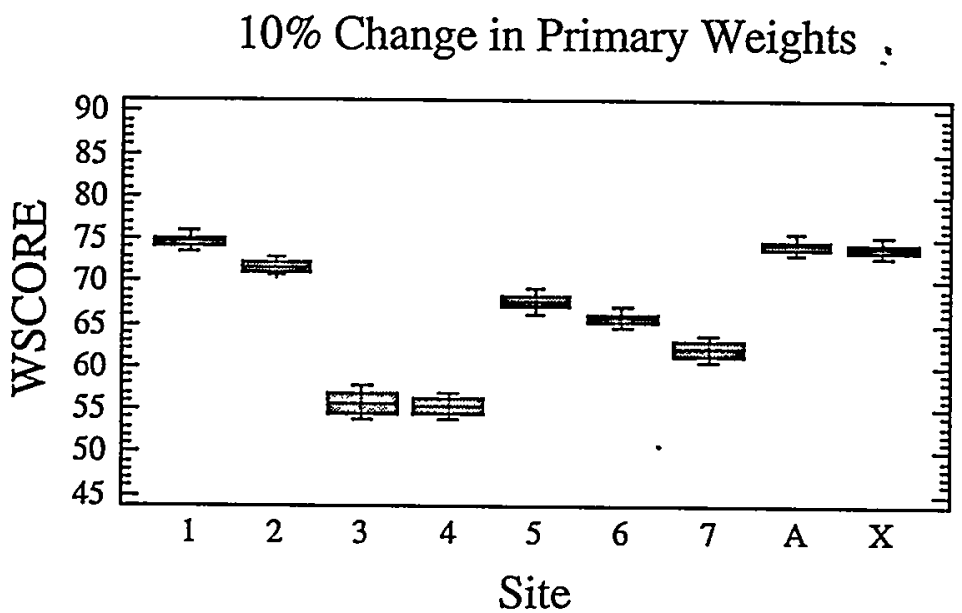

$20 \%$ Change in Primary Weights

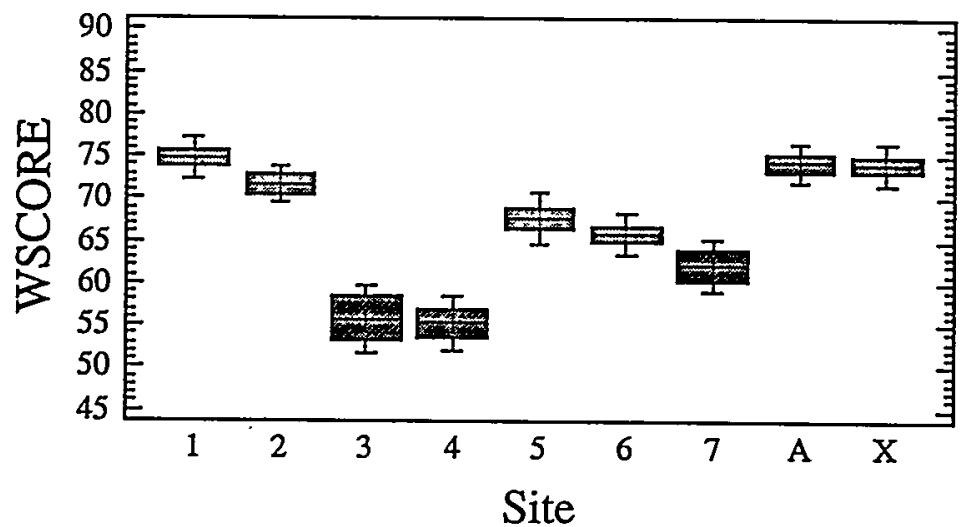


30\% Change in Primary Weights

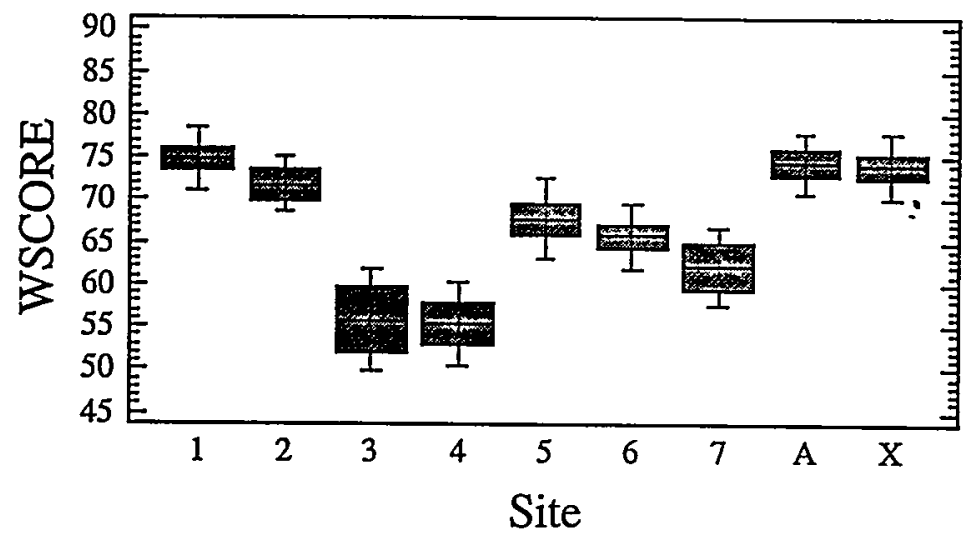

40\% Change in Primary Weights

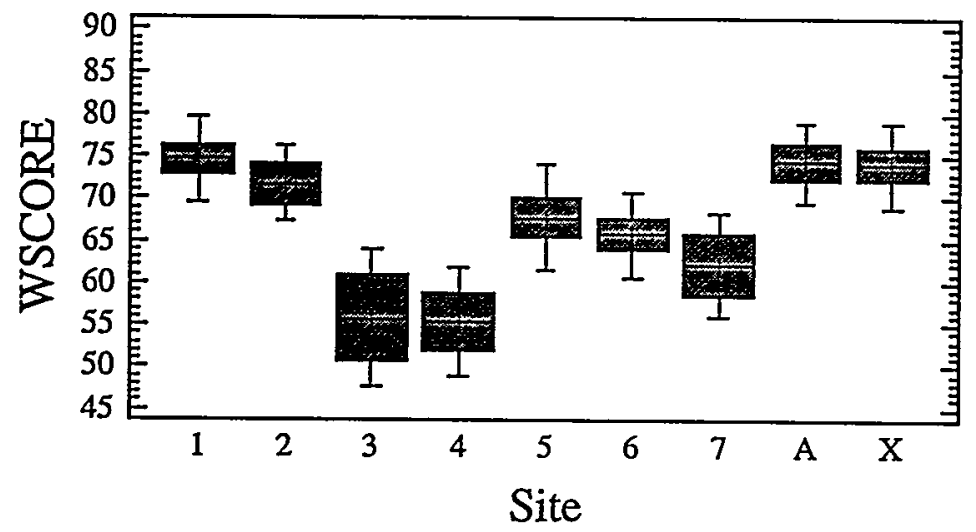

